\title{
Tourist Motivation and Satisfaction of Chinese Senior Tourists on Day Trips
}

By

Shanshan Li

\author{
A thesis \\ submitted to Victoria University of Wellington \\ in partial fulfilment of the \\ requirements for the degree of \\ Master of Commerce
}

Victoria University of Wellington

2019 


\section{Abstract}

Purpose: The study explores the tourist motivation and satisfaction of Chinese senior tourists on day trips. The purpose of this study is to identify the model of tourist motivation and satisfaction for Chinese senior tourist on day trips, thereby filling the theoretical gap in the field of day trips in China.

Design: This study proposes a conceptual framework of the tourist motivation and satisfaction for the Chinese senior tourist on day trips based on the literature in the field and analysing the tourism motivation and satisfaction of Chinese senior tourists on day trips by using the quantitative research method of the positivist paradigm.

Findings: This study validated some of the previous research results in this field and confirmed most of them. Similar to some research results, this study found the most important push motivation category for Chinese senior tourists on day trips is "knowledgeseeking", and the most important pull motivation category is "advantages of the scenic spot". For tourist satisfaction of Chinese senior tourists on day trips, the three most important influencing factors are: "scenic security", "attractive scenery", and "service quality of scenic service personnel". The study also found the demographic characteristics of senior tourists have an impact on tourist motivation and factors affecting tourist satisfaction. For example, fitness is an important reason for people aged 50-55 travel, but it doesn't important to people over 55 years old. Senior people with more knowledge will be more concerned with the needs of intangible cultures. For male seniors, the most important factor affects tourist satisfaction is "attractive scenery". But for the elderly women, the first important factor affecting tourist satisfaction is "scenic security". Furthermore, the results identify as tourism motivation becomes higher, the Chinese senior tourists evaluate the tour quality better. Similarly, as the tourism expectation becomes higher, Chinese senior tourists evaluate the tour quality better, which increases tourist satisfaction. Tourist satisfaction affects the future behavioural intention of Chinese elderly negatively. Meanwhile, the mean value of tourists' future behavioural intention shows that as the tourist satisfaction of the Chinese elderly becomes higher, they tend to recommend to their friends. The lower the tourist satisfaction of the Chinese elderly, the more they tend to complain to their friends. 
Originality and Value: This study has proved some existing theories about tourist motivation and satisfaction of senior tourists can also be applied to Chinese senior tourists on day trips. The academic contribution of this study is the model of tourist motivation and satisfaction for Chinese senior tourists on day trips that has been identified. This empirical model is a new theory for the Chinese day trips field, which fills the theoretical gap in it and it can be used for many other works. Meanwhile, this study can also help other researchers in other related research work. The study may be able to provide some related materials such as research data etc. The findings of this study will help Chinese tourism practitioners responsible for designing tourism products and providing services. This study can help tourism practitioners to understand more about the needs of senior people participating in tourism activities, thus can design suitable tourism products for the senior people.

Keywords: Senior tourist, Tourist motivation, Tourist satisfaction, China

Paper Category: Research paper 


\section{Acknowledgment}

Writing a master's thesis is a long journey. I could not complete this without the help and support of some people during this journey.

First of all, I would like to thank Associate Professor lan Yeoman, my supervisor, who gave me valuable advice and support. Thank you for your kindness and encouragement throughout the process. The problems and doubts encountered in the development process are broken down one by one under your guidance and inspiration, and the thesis can be successfully completed.

I sincerely thank Dr Ina Reichenberger, lecturer in Tourism Management at Victoria University of Wellington. In the midst of busy work, you are still patiently giving me help and guiding me to modify the method chapter.

I also want to thank Megan Key for all your help and support. Thank you for your patience in solving all my problems.

I would also like to thank all the lecturers at the University of Victoria's School of Management in Wellington for teaching me about the knowledge and skills of management. I will cherish them forever.

Finally, I would like to thank my family who gave me the greatest support and encouragement during this journey. Without them, I will not be able to complete it.

Thank you, everyone! 


\section{Table of Contents}

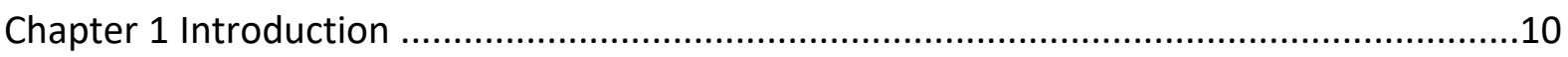

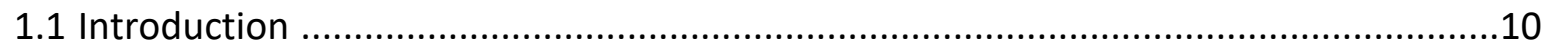

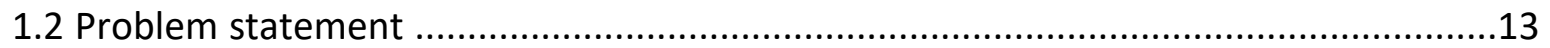

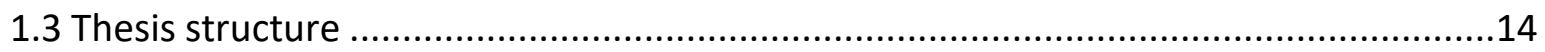

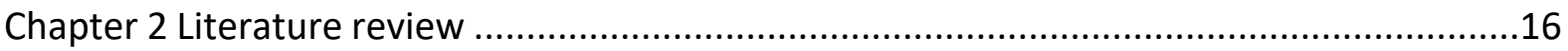

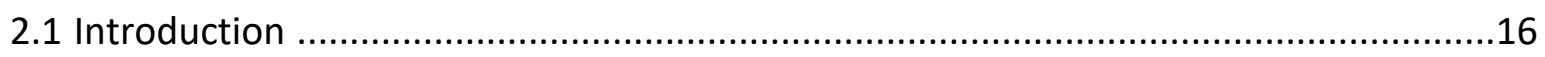

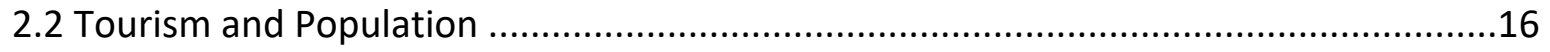

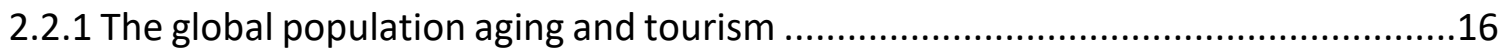

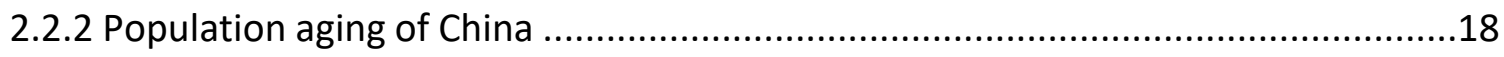

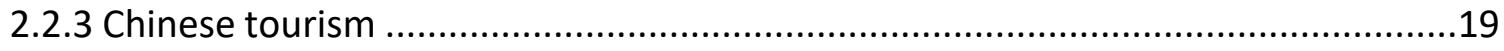

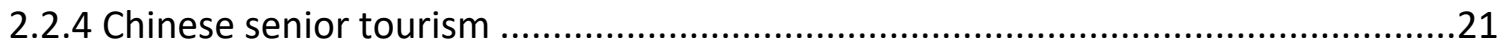

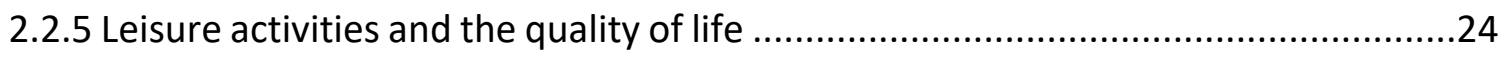

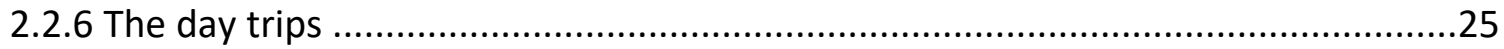

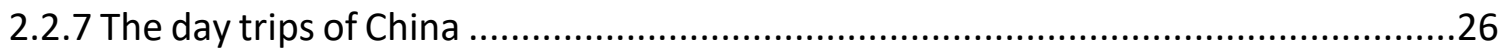

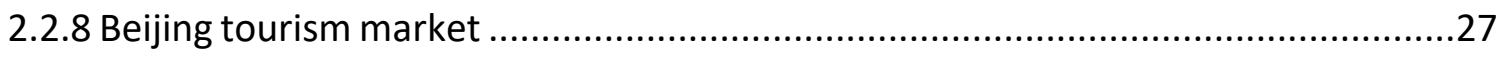

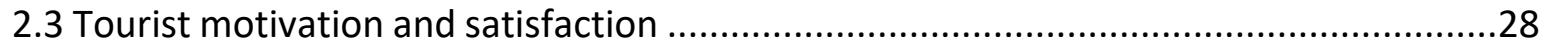

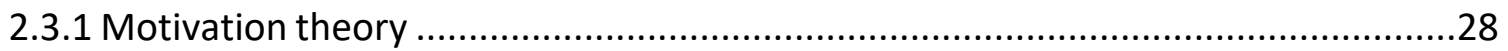

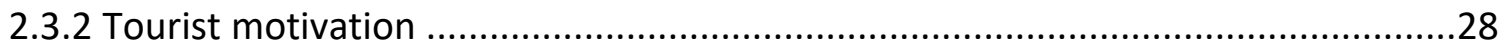

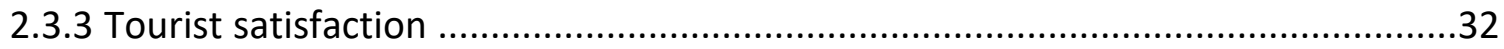

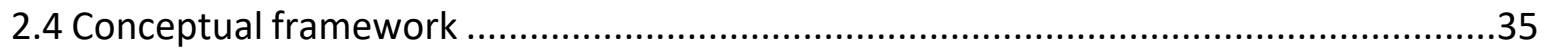

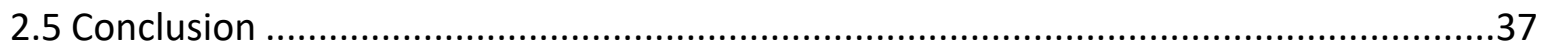

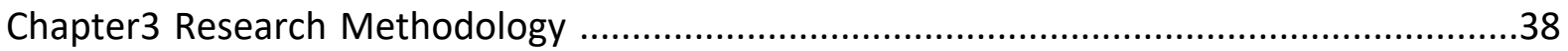

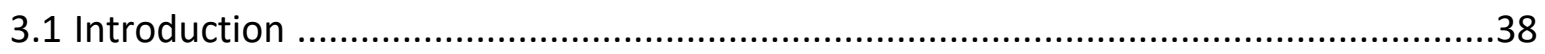

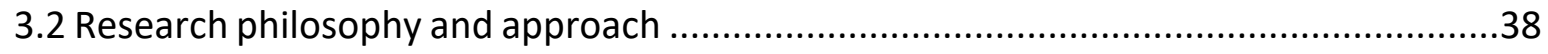

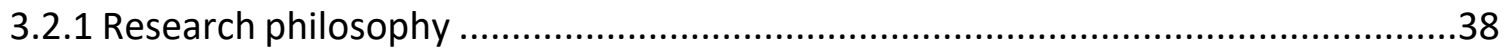

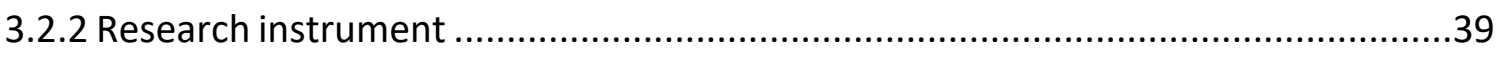

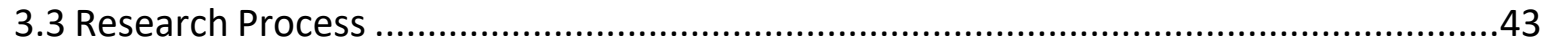

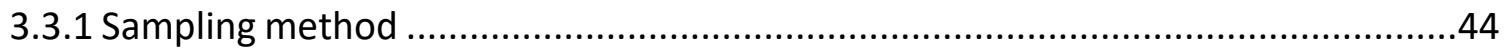




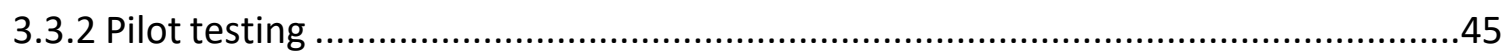

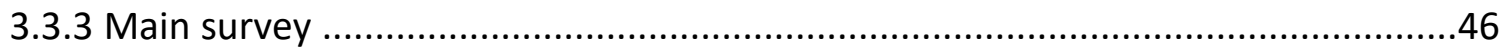

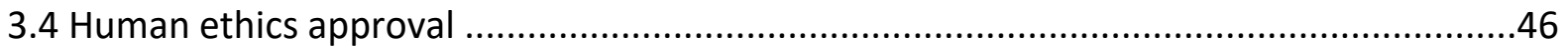

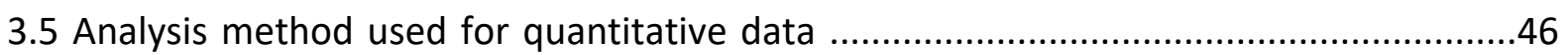

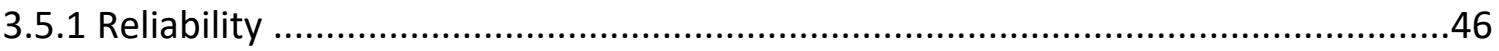

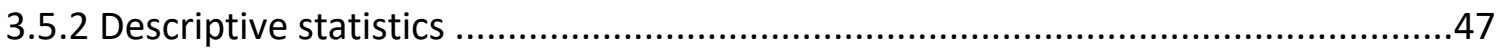

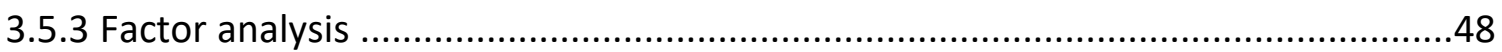

3.5.4 Correlation analysis and regression analysis .................................................48

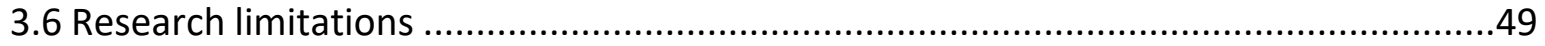

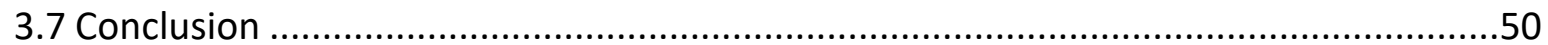

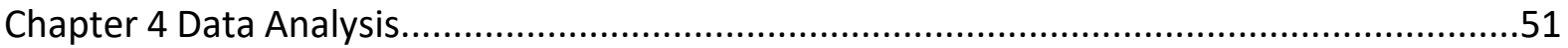

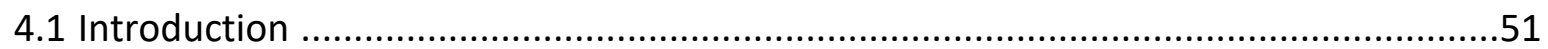

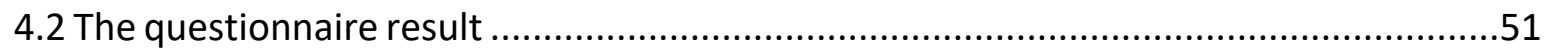

4.2.1 Participant demographic characteristics ...........................................................51

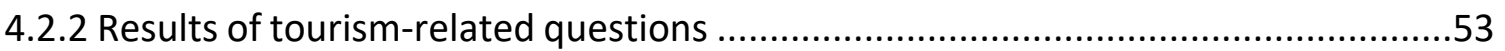

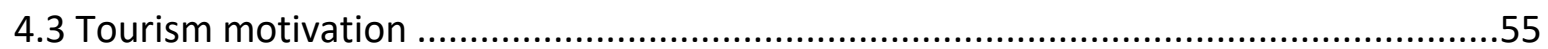

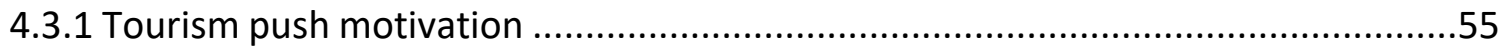

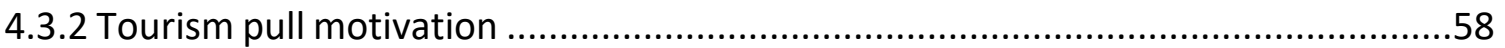

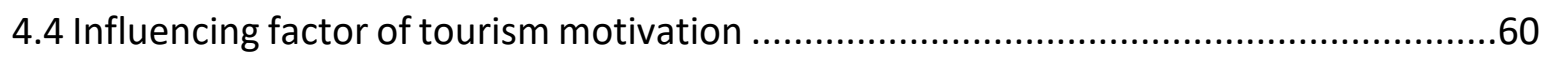

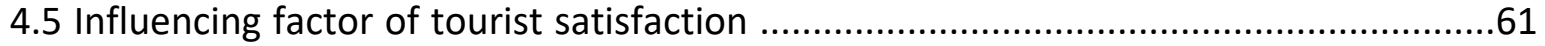

4.6 The influence of tourism motivation on tour quality ................................................63

4.7 The influence of tourism expectation on tourism quality .....................................64

4.8 The influence of tour quality on tourist satisfaction .............................................64

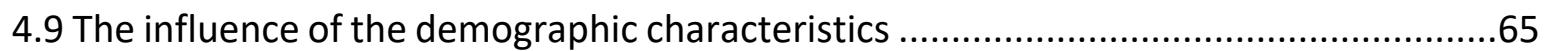

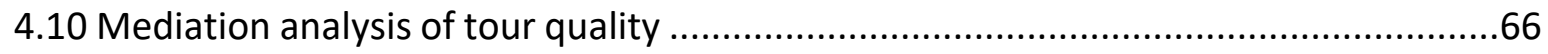

4.11 The influence of tourist satisfaction on tourists' future behavioural intention ..........68

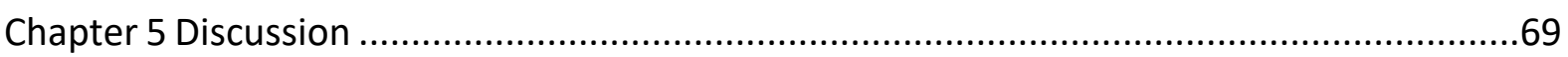

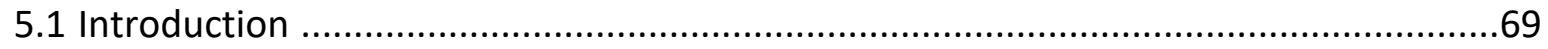

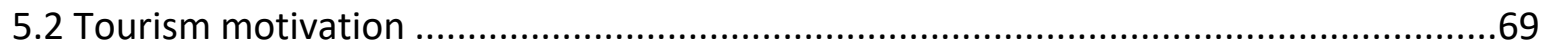

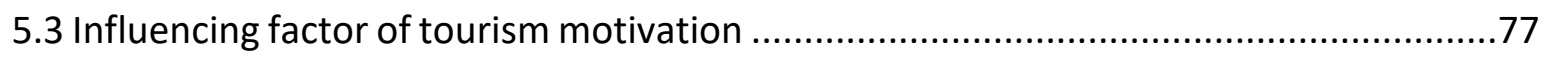


5.5 Relationships among tourism motivation, tourism expectation, tour quality, tourist

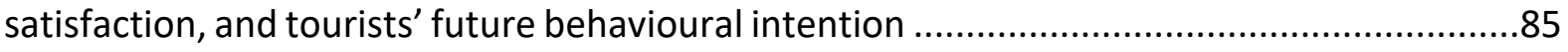

5.6 Model .86

Chapter 6 Conclusion .88

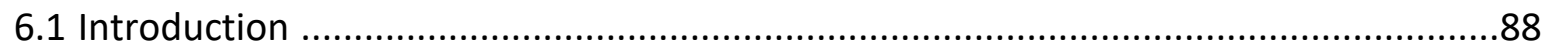

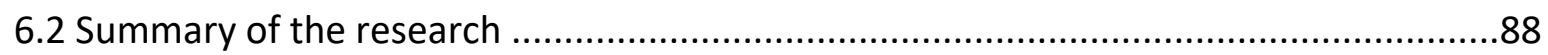

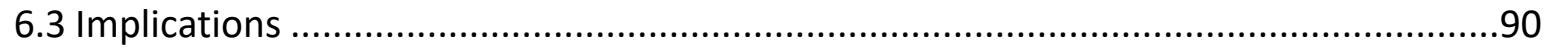

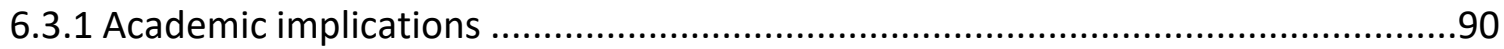

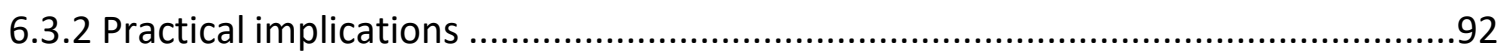

6.4 Limitations and recommendations for future research .......................................93

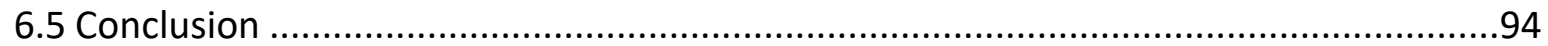

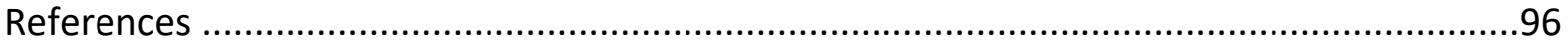

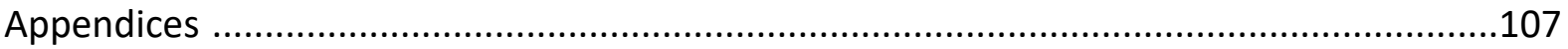




\section{List of Tables}

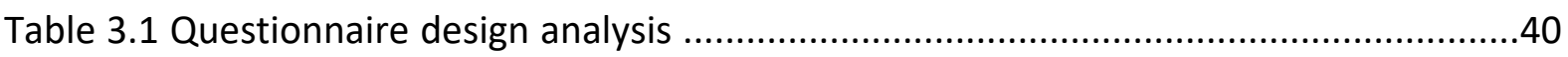

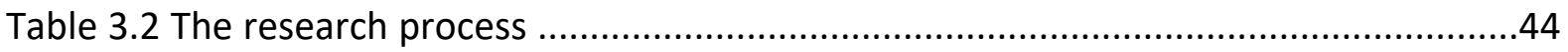

Table 4.1 The demographic characteristics of the participants ..........................................52

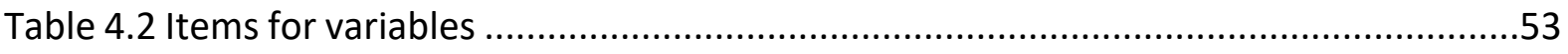

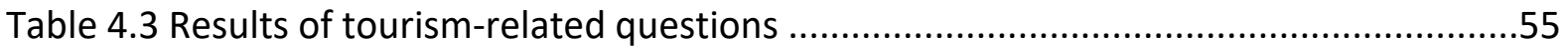

Table 4.4 The reliability of tourism push motivation ...........................................................56

Table 4.5 The KMO and Bartlett's test for tourism push motivation ......................................56

Table 4.6 The total variance explanation for tourism push motivation ...............................56

Table 4.7 The structure matrix for tourism push motivation .................................................57

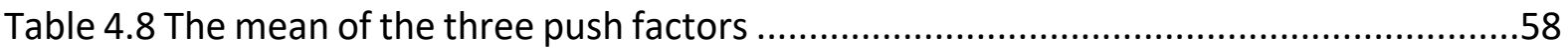

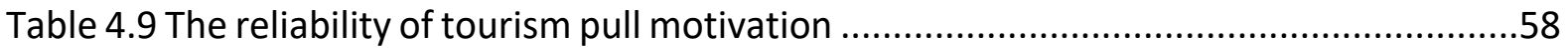

Table 4.10 The KMO and Bartlett's test for tourism pull motivation .....................................58

Table 4.11 The total variance explanation for tourism pull motivation ...............................59

Table 4.12 The structure matrix for tourism pull motivation .............................................60

Table 4.13 The mean of the three pull factors .................................................................60

Table 4.14 The reliability of the factors influencing tourism motivation ..............................60

Table 4.15 The KMO and Bartlett's test for the factors influencing tourism motivation .........61

Table 4.16 The total variance explanation for the factors influencing tourism motivation .....61

Table 4.17 The reliability of the factors influencing tourist satisfaction ..............................61

Table 4.18 The KMO and Bartlett's test for the factors influencing tourist satisfaction ..........61

Table 4.19 The total variance explanation for the factors influencing tourist satisfaction ....62

Table 4.20 The structure matrix for the factors influencing tourist satisfaction ....................63

Table 4.21 The mean of the factors influencing tourist satisfaction ..................................63

Table 4.22 The influence of tourism motivation on tour quality .......................................64

Table 4.23 The influence of tourism expectation on tour quality .......................................64

Table 4.24 The influence of tour quality on tourist satisfaction .....................................65

Table 4.25 The influence of the demographic characteristics ...........................................65

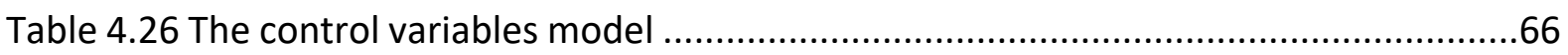

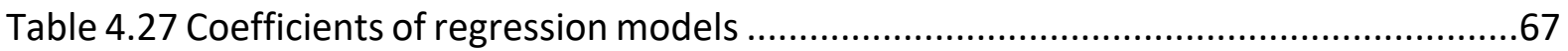

Table 4.28 The influence of tourist satisfaction on tourists' future behavioural intention .....68 
Table 5.1 Tourism motivation items and mean value .........................................................70

Table 5.2 Means of tourism motivation for different genders .........................................72

Table 5.3 Means of tourism motivation for different ages ................................................73

Table 5.4 Means of tourism motivation for different education level ...................................74

Table 5.5 Means of tourism motivation for different annual income ..................................75

Table 5.6 The mean of the push tourism motivation categories .........................................76

Table 5.7 The mean value of factors influencing tourism motivation ....................................77

Table 5.8 Factors influencing tourist satisfaction and mean value .....................................80

Table 5.9 Means of factors influencing tourist satisfaction for different genders ..................81

Table 5.10 Means of factors influencing tourist satisfaction for different ages .....................82

Table 5.11 Means of factors influencing tourist satisfaction for different annual income .......83

Table 5.12 The mean of the factor categories influencing tourist satisfaction .......................83 


\section{List of Figures}

Figure 2.1 A model of senior tourism motivations-Anecdotes from Beijing and Shanghai

Figure 2.2 The conceptual framework for tourism motivation and satisfaction of Chinese senior tourists on day trips

Figure 4.1 The scree plot for tourism push motivation .57

Figure 4.2 The scree plot for tourism pull motivation .......................................................59

Figure 4.3 The scree plot for the factors influencing tourist satisfaction .............................62

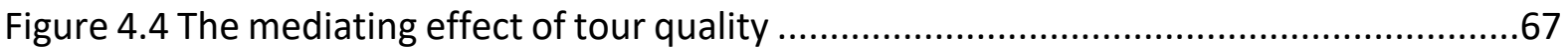

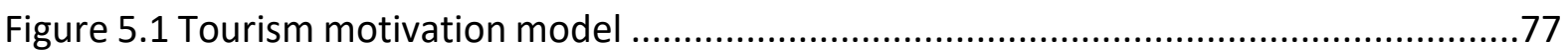

Figure 5.2 Factors influencing tourism motivation ........................................................79

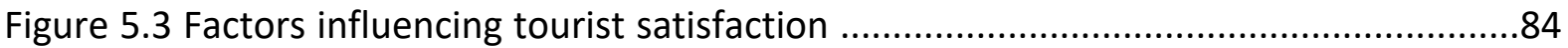

Figure 5.4 The model of tourist motivation and satisfaction for the Chinese senior tourists on day trips 


\section{Chapter 1 Introduction}

\subsection{Introduction}

Tourism is one of the world largest industries from an economic perspective. It does not only bring many employment opportunities to the world but also promotes the development and prosperity. In 2017, the tourism industry provided 313 million job opportunities, which are close to $10 \%$ of total employment, and contributed $\$ 8.3$ trillion, over 10\%, to global GDP (World Travel \& Tourism Council, 2018). In the past few decades, as of 2017, tourism has surpassed global economic indicators for seven consecutive years, with an increase of $4.6 \%$ in 2017 . The performance of Asia continues to remain strong, which is a continuing trend in recent years (World Travel \& Tourism Council, 2018).

At the same time, the issue of population aging has attracted more and more attention around the world. Older people are those who are over 60 years old (United Nations, 2017). In 2017, there were 962 million people aged 60 or above worldwide (United Nations, 2017). According to the prediction of the Department of Economic and Social Affairs of the United Nations (2017), the global elderly population will reach 3.1 billion in 2100, which means the global population will be aging more than three times by 2100 . This prediction indicates many people will enter the later years of their lives in the coming decades.

A country enters an aging society when people over 65 years old are more than $8 \%$ of the population ("Aging of Population.", 2019). Based on this criterion, China has already entered an aging society in 1999. China's population is aging at an unprecedented rate. Chinese elderly population is expected to increase to 418 million by 2035 and to reach the peak at 487 million by 2053, which accounts for over 33\% of the country's whole population (China statistics bureau, 2017). This means China will become a highly aging country in the near future. The impact of population aging on total market demand will inevitably lead to changes in market structure. Paying attention to the consumption of the elderly is not only conducive to improving the quality of life of the senior people but also contribute to the development of the social economy. 
In the past years, the Chinese tourism industry has gone through four stages of start-up, growth, expansion and overall development. At present, the tourism industry in China is rapidly developing. In 2017, the United States still ranked first in the direct and overall contribution of tourism to GDP. But by 2028 , China is expected to surpass the United States in these two areas. In the next decade, China's tourism market is expected to reach $\$ 1.3$ trillion, with an average annual growth rate of $6.6 \%$. China's tourism industry is predicted to directly create 34 million jobs, far more than the rest of the world (World Tourism Council, 2018). With the overall progress of Chinese society, the daily life of the Chinese people is increasingly inseparable from tourism activities (China Industry Information, 2018). According to a survey, one-fifth of the people participating in tourism activities are elderly (Hu, 2017).

Unlike young people, older people have more personal disposable time after retirement, which greatly increases their likelihood of participating in tourism activities. Therefore, the elderly constitutes an important tourism market (Moscardo \& Green 1999, Goggin 1999). As the global population ages, the senior market continues to expand. The impact of the senior market on tourism is also increasing (Horneman, Carter, Wei, \& Ruys, 2002).

However, as the labour force reduces, and the per capita wealth declines, leading to a pension crisis, and the health problems of the elderly will gradually increase. All of this will lead to a reduction in travel tendencies of elderly people (Yeoman, et al., 2010). The development of tourism depends on the awareness of tourism product developers and service providers on demographic changes influence consumer behaviour (Horneman, Carter, Wei, \& Ruys, 2002). Promoting the initiative of travel of people and increasing the availability of tourism products are the driving force for sustainable tourism development (Qian, 2012). Therefore, understanding the purpose, demand, and satisfaction of participating in the tourism activities of the senior people is critical for the tourism.

Lee, Jeon, and Kim (2010) argue that understanding the expectations and motivations of visitors will help improve the quality and satisfaction of travel. Studies in many Western countries have shown the common motivations of the elderly tourists are "rest and relaxation", "physical exercise", "social interaction", and "learning” (Fleischer, \& Pizam, 
2002, Horneman, Carter, Wei, \& Ruys, 2002). However, the motivations of senior tourists from developed and developing countries vary widely. A tourist motivation model based on the development of developed and Western cultures may not be suitable for analysing the motivations of senior tourists from developing and non-Western societies.

Tourist satisfaction is an assessment by comparing tourist expectations with their experience during the travel (Wang, Liu, \& Zhang, 2010). Lee, Jeon, and Kim (2010) analysed factors related to tourist satisfaction. They believe that the motivation of tourists has a positive influence on the tour quality, which has a positive influence on tourist satisfaction. Tourist expectations play a very important role in their satisfaction. When the travel experience exceeds their expectations, tourists will be satisfied with the assessment of tourist satisfaction. Conversely, when the travel experience does not meet previous expectations, the consequences are usually emotional dissatisfaction. However, this tourist satisfaction model is suitable for Chinese tourists visiting South Korea. For local tourists in China, the suitability of this model is yet to be verified.

A notable feature of large cities in terms of tourism is that there are many independent tourists and large demand for day trips (Zhang, 2000). A one-day tour means a tourist's visit to a certain place and returns on the same day (without staying overnight). This definition is often adopted in tourism statistics (Qin, \& Xu, 2012). Day trips are often the most important travel requirement for individual visitors during their stay in the city. In addition, older people are more suitable for short trips due to special reasons such as their health situation (Huber, Milne, \& Hyde, 2018). A survey in China also showed that older people prefer to take short trips (Gao, Z.F., 2018). Therefore, day trips with short time and low cost have become an important choice for the elderly. However, the literature on tourist motivation and satisfaction for senior people on day trips is rare in China. Many kinds of literature in this field is about the causes and solutions of the disorder of Chinese day trips market.

In summary, the development of population aging will lead to changes in the market structure, that is, the senior market is gradually expanding. The elderly has gradually become an important market for day trips. Enhancing the enthusiasm for traveling tourists and increasing the applicability of tourism products are important to the sustainable 
development of Chinese tourism (Qian, 2012). Therefore, the study of tourist motivation and satisfaction of senior tourists on day is very important to the Chinese tourism industry. However, the literature on tourist motivation and satisfaction of Chinese senior tourist on day trips is rare. This is a gap in this field. In order to fill this gap, the study attempts to explore the motivation and satisfaction of senior people participating in tourism activities from the perspective of Chinese day trips senior tourists. In order to achieve the purpose, this research will answer the question "what are the factors that determine the satisfaction and motivation of day trips?"

\subsection{Problem statement}

It is necessary for government and tourism practitioners to understand the various needs of the growing senior market to design new tourism products for senior tourists. In addition, it is also important to understand the satisfaction of senior tourists, which is very beneficial to increase the competitiveness of the tourism destination itself.

In order to solve the above issue, the following sub-questions need to be answered by the study:

1. What is the tourism motivation of Chinese senior tourists on day trips?

2. What factors will have impacts on the motivation of Chinese senior tourists on day trips?

3. What factors will have impacts on the satisfaction of Chinese senior tourists on day trips?

4. What are the relationships among tourism motivation, tourism expectation, tour quality, tourist satisfaction, and the future behavioural intention of tourist?

All of the above research questions are intended to identify the model of the tourist motivation and satisfaction of Chinese senior tourists on day trips. This empirical model is a new theory for the Chinese day trips field, which fills the theoretical gap. It is the academic contribution of this study. Meanwhile, this study can also provide recommendations for government and tourism practitioners based on the findings. 


\subsection{Thesis structure}

This study is divided into six chapters. The following is the structure of the thesis :

Chapter 1, "Introduction", introduces the issue of population aging and the development of tourism. This chapter presents the topic of the study, identifies the research question, and four research sub-questions.

Chapter 2, "Literature Review", provides readers with an overview of the findings of the literature related to this research, including the population aging, the development of the tourism industry in China, the current situation of day trips in China, and the tourism motivation and satisfaction of senior tourists. Finally, this chapter presents a conceptual framework according to the understanding of the literature in the field, the relationship between each variable and four hypotheses.

Chapter 3, "Research Methodology", identifies the research paradigm and method used in the study. This chapter also describes the entire research process and how to analyse the data. At the end of this chapter, the limitations of the study are presented.

Chapter 4, "Data Analysis", describes the results of the study and all study data were quantitatively analysed. This chapter identifies the tourism motivations of Chinese senior tourists on day trips, the factors that influence tourism motivation of Chinese senior tourists on day trips, the factors that influence tourist satisfaction of Chinese senior tourists on day trips, and identifies the relationship between variables, and verifies the four hypotheses proposed earlier.

Chapter 5, "Discussion", the research findings were discussed in this chapter. The impact of demographic characteristics on tourism motivation and satisfaction of Chinese elderly tourists is also discussed in this chapter. At the end of the chapter, the model of the tourism motivation and tourist satisfaction of Chinese senior tourists on day trips was identified. 
Chapter 6, "Conclusion", revisited the research purpose, research process, and research findings. Meanwhile, the academic implications, the practical implications are also included in this chapter. Recommendations for future research are provided at the end of the chapter. 


\section{Chapter 2 Literature Review}

\subsection{Introduction}

The focus of the study is on senior tourist motivation and satisfaction. Therefore, the understanding of the state of the elderly tourism market in the world and tourist motivation and satisfaction is necessary. Reviewing previous literature on tourist motivation and satisfaction for senior tourists is critical because it provides relevant information for this study to propose a conceptual framework. It also provides information about relevant statistical tests and analytical approaches.

\subsection{Tourism and Population}

\subsubsection{The global population aging and tourism}

Tourism is one of the world's largest economies. It not only provides a great number of job opportunities but also drives the development of world import and export trade. An analysis (World Tourism and Tourism Council, 2018) shows that in 2017 the industry provided 313 million job opportunities, which accounts for $9.9 \%$ of total employment and contributed $\$ 8.3$ trillion, which accounts for $10.4 \%$ of global GDP.

2017 is the year with the largest increase in GDP in decades, and global consumer spending remaining robust. The tourism industry is no exception, which directly increased by $4.6 \%$ and beat global economic indicators for seven consecutive years. Asia, in particular, performance still strong, which continues the trend of last several years. In the meantime, there has been a strong recovery in the industry in countries such as Egypt, Turkey, and Tunisia that had previously been heavily affected by terrorism, demonstrating the resilience of tourism (World Travel \& Tourism Council, 2018). In 2017, Tourism of China, Japan, UK, Turkey, Spain, Saudi Arabia, and UAE performed extraordinarily better than the overall economy. 
The population aging issue attracts increasing attention globally. With the growth of the global elder population and the elders' wish to stay healthy, medical tourism gradually becomes a mainstream tourism product. However, as the population ages, the number of people working decreases relative to the number of people who do not work, the per capita wealth declines, leading to a pension crisis, and the health problems of the elderly will gradually increase. All of these will cause the reduction of the propensity to travel (Yeoman, et al., 2010).

The elderly is defined as people aged 60 and over (United Nations, 2017). According to the international standard, a country enters the aging society when $8 \%$ of the whole population is over 65 years old ("Aging of Population", 2019). Some developed countries have become aging countries in the middle of the last century. For example, France, the world's first aging country, the "old kingdom" Sweden, the "longevity kingdom" Japan, Spain, and Germany (Wang, Liu, \& Lin, 2013). David predicts that either developed or developing countries are facing serious aging population pressure by 2050 , and population aging will be a serious problem worldwide (David, E. B., David, C., \& Günter, 2011). According to the data of the Department of Economic and Social Affairs of the United Nations (2017), in 2017, the number of people aged over 60 reached 962 million in the global. It is predicted that by 2050, this number will more than double to 2.1 billion, and will reach 3.1 billion in 2100 , which means by 2100 , the global aging population will be more than three times than the current number. This suggests a great number of people will enter the old age of their life in the coming decades.

For elderly people, they are not like young people who have to work or study every day. They have free time and income after they retired (Euromonitor, 2013). Their time and financial situation will greatly increase their travel opportunities. Therefore, elderly people constitute an important tourism market segment (Moscardo \& Green 1999, Goggin 1999). As the development of the global population aging, the senior market expands continually, and its growth potential is huge. The impact of the senior market on global tourism is growing (Horneman, Carter, Wei, \& Ruys, 2002). 
Tourism practitioners often divide all older people into a homogeneous market segment. However, this classification does not provide insight into the diverse travel preferences of older people. According to the demographic segmentation of the elderly market, it is possible to study the diversity of tourism needs, tourism motivation and tourism behaviour of the elderly in a more detailed manner. This will enable tourism practitioners to design and provide tourism products and services that are specifically targeted for senior tourists. Therefore, the growth of tourism depends on the awareness of tourism product designers and service providers about the demographic changes that influence consumer behaviour (Horneman, Carter, Wei, \& Ruys, 2002). It is expected that baby boomers (born between 1945 and 1960) will have different lifestyles and attitudes compared with the current older generation (Moisey and Bichis 1999). Therefore, as the "baby boomers" enter the senior tourism market, it becomes more significant for the industry to understand the upcoming travel trends.

\subsubsection{Population aging of China}

As mentioned above, a country enters an aging society when people over 65 years old are more than $8 \%$ of the country's population ("Aging of Population.", 2019). Based on this criterion, China entered the aging society very early, which in 1999. As China's senior population exceeded 100 million in 2015, China became the country that has the largest senior population in the world (China National Committee on Ageing, 2015). Statistics data of China statistics bureau (2017) shows that in 2016, there were 150 million people aged 65 or above in China, which means the senior people are about $10.8 \%$ of the whole population, 0.7 percentage points higher than in 2014. According to October 2016 data from the China National Committee on Ageing, 15.76\% of China's population, which is about 215 million, were people over 60 years old. Furthermore, China's population is aging at an unprecedented rate. China's elderly population is expected to increase to 418 million by 2035 and to reach the peak at 487 million by 2053, which accounts for more than $33 \%$ of the country's total population (China statistics bureau, 2017). This means China will become a highly aging country in next few years. 
Based on the data from the China statistics bureau, the average life expectancy of the population is 76.34 years (China statistics bureau, 2017). The Chinese people are retired at around 55 years old (The National People's Congress of the People's Republic of China, 1978a, 1978b). This means that in China, retired seniors have at least 15 to 20 years of leisure life that do not need to work. In the next 25 to 30 years, the life expectancy of the age of the Chinese population will increase to about 81.1 years old, five years more than now. It is expected to rise to 87.4 years old by 2100 (United Nations, the Department of Economic and Social Affairs, Population Division, 2017). This means that the average life expectancy of China's population will be extended by 11 years in the near future. Moreover, their leisure life will extend to 25 to 30 years. The increase in life expectancy means that the number of senior tourists will continue to increase. However, older tourists also have their own unique needs, such as the need for medical care. The increase of elderly tourists will also complicate the structure of tourist families such as the three generations of family travel together. The future tourism industry will have to face the diversity brought by the increase of elderly tourists (World Tourism Organization, 2012).

Judging from the history and current situation of China's aging population, the impacts on the total market demand will inevitably lead to changes in the market structure. Therefore, it has become an important way to maintain the stability and prosperity of the market to adjust the product structure timely according to the change of market demand, develop the aged industry and expand the aged market. Paying attention to the consumption of the elderly is not only conducive to improving the elderly' quality of life of the senior people, but also a new economic growth point driving domestic demand (Rong, \& Zhang, 2006).

\subsubsection{Chinese tourism}

Since the implementation of China's "reform and opening" policy in 1970s, the tourism industry in China has experienced four stages: arising, development, outspread and comprehensive development. China has accomplished a historic leaping development from a short-circuited tourism country to a major tourism country and established a market pattern in which the national mass tourism consumption is the mainstay and domestic and international tourism are coordinated developing (China Industry Information, 2018). 
Statistics (World Travel \& Tourism Council, 2018) on the tourism direct contribution to GDP in 2017 showed that the United States ranked first with $\$ 509.4$ billion, followed by China with $\$ 402.3$ billion. Statistics (World Travel \& Tourism Council, 2018) on the tourism direct contribution to employment in 2017 showed China ranked first with 28,250 positions offered.

A study that predicts changes in consumer spending shows the demand for different products at different income levels. The demand for domestic tourism starts at an income level slightly above $\$ 35,000$, while international travel starts with a higher income of $\$ 50,000$. By 2027, China is expected to have more than 64 million new households with incomes above $\$ 35,000$. India is in second place, with about 9 million new families, but there is a big gap compared with China (World Travel \& Tourism Council, 2018).

The USA remained number one in the 2017 data on direct and overall contributions to GDP made by the travel and tourism industry. But by 2028 , China is expected to overtake America on both counts. The Chinese tourism market is predicted to create $\$ 1.3$ trillion over the next decade (compared with $\$ 404.8$ billion in the U.S.), with an average annual increase of 6.6 percent. In addition, the Chinese tourism industry is predicted to directly provided 34 million occupations in the near future, far more than the rest of the world (World Travel \& Tourism Council, 2018).

According to the Chinese "13th five-year plan" for tourism development, China's national strategic system has covered all aspects of the tourism industry, and tourism has become one of the strategic pillar industries during the "12th five-year plan" period, and it contributed $10.8 \%$ to China's national economy in 2015 . As a tourism resource-rich country with the world's biggest domestic tourism market, China has become the world's fourth most popular destination and the largest international tourism consumption country. In late 2017, the quantity of 5a-level tourist attractions was 249 in China. In terms of visitor reception and tourism revenue in 2017 , compared with 2016 , the number of domestic tourists increased by $12.8 \%$, which was over 50 billion person-times, and domestic tourism revenue reached 4,570 billion CNY, increased by $15.9 \%$. There were 139.48 million inbound 
visitors, increased by $0.8 \%$. With a $2.9 \%$ growth rate, International tourism revenue reached to 123.4 billion CNY. Over 130.51 million Chinese tourists travelled overseas, and the number has increased by $7.0 \%$. An Overall 54,000 billion CNY revenue, increased by $15.1 \%$, was made from tourism. As the development of Chinese society, tourism activities have become increasingly popular to Chinese people (China Industry Information, 2018).

At present, the tourism industry in China is in a rapidly developing period still. First of all, there are many strategic opportunities, faced by the Chinese tourism industry currently. With the steady growth of residents' income, the consumption structure has been accelerated and upgraded, the paid vacation system has been gradually implemented, the holiday system has been constantly improved. All of these are resulting in tourism consumption release fast and laying a good basis for the tourism industry development. Second, tourism has been confirmed as a happiness industry. Governments at all levels attach more importance to tourism developing, and will further optimize the development environment of the tourism industry. Third, with the acceleration of the developing of highway, high-speed railway, railway station, airport, and other transportation infrastructure of the tourism, the continuous improvement of the modern integrated transportation system, acceleration of the construction of facilities for tourist reception such as hotels, restaurants and scenic spots, and constant increase of tourism supply, will stimulate the growth of tourism consumption rapidly. In the meanwhile, the scale of middle-income people continues to expand, tourism consumption capacity and tourism consumption will increase continuously. Tourism activities have become critical to Chinese people's leisure lives. The number of tourists has expanded rapidly. Finally, as a country with an ancient civilization and with an emerging economy, the attraction of Chinese international tourism is still strong, there is still a lot of space to expand its main tourist market, and the inbound tourism's growth potential is huge (China Industry Information, 2018).

\subsubsection{Chinese senior tourism}

An increase in life expectancy per capita will slow the mortality rate in the elderly population, which will increase the size of the elderly population year by year. A survey on 
the tourism needs of the elderly people found that more than half of the elderly are willing to participate in travel activities (Gao, Z. F., 2018). In other words, in the future, there will be more and more elderly people in China who have decades of leisure and entertainment after retirement, if they have enough wealth.

As mentioned above, it is expected that the population of elderly people would increase to 418 million by 2035 and to 487 million by 2053, which is over 33\% of China's population (China bureau of statistics, 2017). Based on a survey by the China National Committee on Ageing, one-fifth of the number of people who travel are elderly (Hu, 2017). However, in the face of such a large tourism target market, China's high-level planning for the elderly tourism population has not yet started, the existing tourism products do not fit the elderly population well, and cannot satisfy the growing requirements of the elderly tourism market, and the tourism industry is in the stage of actively responding to the aging of the tourist population.

A survey on the tourism needs of the elderly people found that $39 \%$ of the elderly aged 55 to $59,29 \%$ of those aged 60 to $64,17 \%$ of those aged 65 to 69 , and only $15 \%$ of those over age 70 have travel needs. Among the elderly, the younger ones are in the relatively good physical condition and have a high spirit of tourism. As a major portion of the elderly, they occupy the majority of the tourism market (Gao, Z. F., 2018). In another survey of tourism intention of the elderly, more than half of the elderly are willing to participate in travel activities, more than half of the elderly tend to travel by themselves, and $45 \%$ of the senior people want to travel within groups. According to the number of trips, $41 \%$ of the elderly choose "once a year", 38\% choose "twice a year", 12\% choose "three times a year", and 79\% choose "more than four times a year". $40 \%$ of the elderly choose to travel in the province, $16.8 \%$ choose to travel nationwide, while nearly $9 \%$ choose to travel overseas, and more than $5 \%$ choose "uncertainty". Based on the results of the survey, most of senior people like to travel and they like to join local and provincial tourist groups on short trips (Gao, Z. F., 2018).

The consumption habits, ways, and special needs of the elderly people stimulate the emergence of special goods and services and the development of elderly industries such as 
tourism (Rong, \& Zhang, 2006). Therefore, the advent of an aging society will give birth to a large and important senior market. As the size of the elderly market continues to increase and the number of tourism activities increases, the tourism industry becomes more and more interested in the elderly population (Huber, d., Milne, s., \& Hyde, k. f. 2018).

Kim, Woo, and Uysal (2015) have verified that travel can improve the mental and physical health of the elderly and can increase their life satisfaction. Tourism plays an important role in the leisure and overall quality of life of senior people. Therefore, the development of China's senior tourism market is a great significance of China's implementation of a healthy aging strategy, and China's social and economic development.

Due to the special reasons such as the physical health of elderly people, day trips are very popular in the senior tourism market. Due to the family responsibilities and health of the elderly people, most of the time they choose the day trips. The day trips are a type of tour that people can visit attractions and go home on the same day. Day trips are not only can take a short time and a short distance, and also cost less. This gives those elderly people who have time but not wealthy a different choice. In recent years, some tourism service organizations in China have made efforts to develop multi-level and diversified tourism products for senior tourists and achieved initial results (Hu, X. M., 2017). In recent years, forest tourism has begun to attract more and more attention from Chinese consumers. According to preliminary estimates, in 2018, the national forest park received more than 1 billion tourists, and the tourism revenue was nearly 100 billion CNY (Jiang, 2019). According to information released by the State Forestry and Forestry Bureau, 25 provinces and cities such as Beijing, Fujian, and Shanxi have successively established forest tourism companies or forest travel agencies, and have entered the market to seize this potential huge tourist group (Jiang, 2019). At present, China's forest tourism products are mainly divided into forest-based recreational tourism mainly based on elderly recuperation, and forest-themed tourism products such as outdoor fitness, self-driving tour, and parent-child tours. The former is a new category introduced in Beijing in 2012, and it is still in its infancy and has not yet formed an industrial chain and scale. 
However, there are still a great number of issues in the elderly tourism market development in China. First, there is a lack of professional tourism products for senior tourists in the current market. Some low-priced senior tourism groups hide some traps such as compulsory shopping and hidden consumption. The poor quality of the products has seriously affected the travel enthusiasm of the senior tourists. Second, the service of the tour guides is not all good. Some tour guides are not careful and patient enough, and the service consciousness is low. It may lead to serious consequences which are the increase in the accident probability of the senior tourists (Hu, X. M., 2017). According to media reports, the "Legal Daily" reporter conducted incomplete statistics and found that since 2017, the media has at least publicly reported 95 incidents of personal injuries in tourist attractions, including 66 in 2017 and 29 in 2018 (Chen, \& Zhao, 2018). At present, the security situation of the entire tourism industry is very serious, and there are many risks and hidden dangers. In recent years, aerial swings, bungee jumping, glass plank roads, and glass viewing platforms, etc., as the new tourist attraction projects, have attracted numerous visitors. However, there are some security risks for these tourist attraction projects. If the safety factor is ignored in the scenic spot, it will not only cause great economic losses but also cause the personal safety of tourists to be threatened.

\subsubsection{Leisure activities and the quality of life}

The quality of life generally includes two dimensions: objective and subjective. In the subjective dimension, it refers to perception of the quality of life, life satisfaction, subjective well-being, etc. (Uysal, Sirgy, Woo, \& Kim, 2016). Two studies by Neal, Uysal, and Sirgy in 1999 and 2007 demonstrated that people's satisfaction with tourism activities has an impact on their leisure life satisfaction. The holiday experience helps to improve leisure life satisfaction and thus improve people's overall life satisfaction. Gilbert and Abdullah (2004) also found that vacations can help people experience a higher overall quality of life.

The experience in trips can improve the satisfaction of the life of the elderly. Kim, Woo, and Uysal (2015) have proved that satisfaction with the experience of tourism activities affects the leisure life satisfaction of older people positively, and thus influence their overall quality of life positively. In other words, the more satisfied the elderly are with the travel 
experience, the more they feel satisfied with their leisure life, and thus will improve their assessment of the quality of overall life. Therefore, for the senior market, leisure activities and travel are very important.

\subsubsection{The day trips}

The character of day trips is traveling to a destination that is nearby in a short time, generally not lasting more than 24 hours and usually does not include overnight service. It differs from other forms of tourism mainly in their duration, not in radius. In the form and essence, it is a comprehensive type of tourism movement (Stetic, Simicevic, \& Stanic, 2011).

Due to the negative impact of the rapid development of human civilization and technology, people need to stay and relax in the natural environment. Except for rest and relax in nature, more and more tourists also want to familiar with the cultural history and involving other tourism activities. Therefore, in addition to special natural conditions, the city has gradually become a choice for tourists (Stetic, Simicevic, \& Stanic, 2011).

As mentioned above, day trips include a maximum of 24 hours of travel, meaning that it does not have an overnight stay, which means that the total cost is lower than other types of travel because it does not include accommodation costs. Therefore, day trips are suitable for very wide people, and their clients are not only tourists who have high purchasing power, but they also open up the possibility of including more participants. This type of tourism is becoming an increasingly critical opportunity for the development of urban destinations today (Stetic, Simicevic, \& Stanic, 2011).

In addition, in the living conditions of technology like the Internet, mobile phones, computers, and others that are beneficial to the development of our civilization, our life has generally accelerated. People are busy with all kinds of things that they only have a small amount of time to entertain and relax. As a result, there is a slight increase in the demand for day trips and short-term relaxation for potential visitors. Potential short-distance travellers prefer to choose destinations nearby because they won't waste too much time (Stetic, Simicevic, \& Stanic, 2011). 
Due to world trends indicate the excursions have further development and growth, excursions are considered to have great potential for development in the future (Stetic, Simicevic, \& Stanic, 2011).

\subsubsection{The day trips of China}

Day trips mean a tourist's visit to a certain place and returns on the same day (without staying overnight). This definition is often adopted in tourism statistics (Qin, \& Xu, 2012).

Day trips are divided into three forms according to the travel mode, that is, self-service individual tour without relying on travel agencies, individual within group tour relying on random travel agencies selected after arriving at the destination, and conventional group tourism from the departure area (Qin, \& Xu, 2012). Self-service individual tour and individual within group tour are called "Individual Tourism" by the industry. Conventional tourism, which is provided directly by travel agencies as a package service, has relatively little demand for public services at the destination. However, individual tourism often needs to resort to convenient and reliable public service system of destination tourism and standard tourism management agencies to complete its tourism activities. The day trips are often the most important travel demand for individual tourists during their stay in a city. However, many well-known domestic tourism cities have the problem of chaotic operation of "day trips" market, which is also the biggest problem China has faced in decades in terms of tourism market management (Xu, 2008).

First of all, a group of random and temporary individual tourists in the destination is usually composed of strangers. It is difficult to form a community of interests and it is difficult to protect rights after the "day trips" activity completed. Secondly, companies that operate individual tour business can only take the initiative to pick up passengers at stations, hotels and other places where tourists gather and even hire unemployed people to take customers. The business path is different from that of general travel agencies. Moreover, it is faced with flow consumers, with low operating costs and difficult to guarantee service quality. Third, the individual tourists within the group, especially those who came to local 
for the business and temporarily decide to visit, did not know the information on the attractions in advance. Their stay time was short, and the status of the destination was completely unknown to them. The phenomenon of information asymmetry is more prominent than that of conventional tourists (Qin, \& Xu, 2012).

The difficulty of self-service individual tourists is more obvious than the individual tour group. The cost of rights protection is higher, and even the complaint channel is narrower. At the same time, it is more dependent on the public service system (Qin, \& Xu, 2012).

\subsubsection{Beijing tourism market}

As China's capital, Beijing is one of the world famous historical and cultural cities. It is not only the first choice of destination for Chinese tourists but also the must-visit destination for overseas tourists. In 2017, Beijing received 28,532 million international and domestic tourists. Beijing has already become a very large tourism city (Beijing statistics bureau, 2017). A notable feature of large cities in terms of tourism is that there are many independent tourists and large demand for day trips (Zhang, 2000). Statistics data show that the number of Beijing residents traveling in Beijing is increasing continuously, reaching 109.93 million in 2016, increased by 80\% from 2010 (Beijing statistics bureau, 2017).

According to the results of a survey (Xu, et al. 2008) on the satisfaction of the "Great Wall Ming Tombs" day trip in Beijing, 67.5\% of local tourists were found to be dissatisfied with this day trip. For local tourists, among the unsatisfactory factors, "not enough time for the tour" has become the main factor, "price deception" is the second place, and "no commentator introduces the attractions" is the third reason. Qin, Xu (2012) believes that Beijing's tourism services and some public services for day trips haven't been able to satisfy the huge tourist requires of individual tourists for a long time, and have formed huge problems. This making the tourist on day trips in Beijing not satisfied.

As an aging society developing, the local senior resident market has become more and more critical in the day trip to Beijing. Studying the motivation and satisfaction of senior tourists on day trips is important for the development of tourism in Beijing. 


\subsection{Tourist motivation and satisfaction}

\subsubsection{Motivation theory}

Motivation is believed as the tendency, drive, emotion, and energy associated with learning, effective work, and achievement, and participation can be seen as the action that reflects this tendency, drive, emotion, and energy (Martin, 2007, Martin, 2009). Symbolic motivation and utilitarian motivation are categorised as the two mainly human behaviour drive motivation. The utilitarian motivation is mainly functional or instrumental. It is best addressed through clear and tangible benefits. Symbolic motivation is related to self-esteem and socially recognized needs and to intangible interests (Kreis, \& Mafael, 2014). Martin, Ginns, and Papworth (2017) believe that previous motivation is the drive for subsequent participation.

\subsubsection{Tourist motivation}

Shao Qiwei, director of the China National Tourism Administration, said at the China Tourism day event in Zhangjiajie that tourism is not only important industry in the national economy but also a livelihood industry closely related to citizen's lives. The state council of China decides to establish the "China tourism day" because the key to the tourism development is to constantly improve, rather than curb, citizens' awareness of tourism, and to continuously stimulate, rather than discourage, citizens' enthusiasm for tourism. Promoting the initiative of tourism of the citizen and increasing the availability of tourism products are the ultimate power of sustainable development of tourism (Qian, 2012). This indicates that tourist motivation and especially tourist satisfaction are the keys to tourism development.

Motivation is a psychological state, which is a person attempts to obtain some kind of satisfaction (Bromley, 1990). Moutinho (2000) believes that motivation can be seen as a type of requirement or condition. It can drive individuals to take certain activities that are seen as potentially satisfying. In Mook's opinion (1996), motivation is the reason for human 
behaviour. Mill and Morrison (1985) believe that as long as individuals want to meet their needs, their motivation will arise. To meet the growing needs, customers will definitely buy the product or service after they understand them. This suggests that consumers will be driven by their emotional needs to use tour services (Lee, Jeon, \& Kim, 2010). In the tourism field, motivation is a significant research area (Fodness, 1994). Lee, Jeon, and Kim (2010) believe that aware of the expectation and motivation of tourist will help increase the tour quality and tourist satisfaction.

In recent years, there are many papers on senior tourists' behaviour and tourist motivation all over the world (Guinn, 1980; Huang, \& Tsai, 2003; Jang, \& Wu, 2006; Hsu, Cai, \& Wong, 2007; Kim, Woo, \& Uysal, 2015; Gao, 2018; Huber, Milne, \& Hyde, 2018). Fleischer and Pizam (2002) founded that common motivations of senior tourists were "rest and relaxation", "physical exercises", "social interaction", "nostalgia”, "learning”, and "excitement". In the study of Horneman, Carter, Wei, and Ruys (2002), motivations frequently appeared were "rest and relaxation", "visiting friends and relatives", "physical exercise and fitness", "education and learning". In their research results (Horneman et al., 2002), the motivation of the elderly people to travel has a clear tendency to pay attention to health, which indicates that the reason for senior tourists to travel gradually changes in a positive way. The findings of Muller and Strickland (1995) show the elderly have a desire to be aware of the changes in the surrounding world. Travel is an opportunity for older people to meet the desire to learn and discover. As a reason to attract tourists, food has become a new field in the tourism market (Horng and Tsai, 2010). Many destinations use local unique food to attract the attention of visitors (Lin et al., 2011). Senior tourists are growth to a significant market because they have both purchasing power and time, so they will look for delicious food at destinations (Balderas-Cejudo, Patterson, \& Leeson, 2019). Therefore, food has also become a tourist motive for elderly tourists. Shopping is also an important tourist motivation for tourists. Visitors can purchase local souvenirs during the tour to commemorate or give friends as a gift (Bowen \& Clarke, 2009). Shopping may be one of the considerations for tourists to choose their destination (Moscardo, 2004), or all of the reasons (Lehto, Chen, \& Silkes, 2014). 
Huang and Tsai (2003) analysed Taiwan senior tourists' motivations when studying the behaviour of them. Among the 12 motivational choices, the travel motivation of Taiwanese elderly tourists is concentrated on five options: "Get rest and relaxation" (35.6\%), "Meet people and socialization" (20.1\%), "Spend time with immediate family" (11.6\%), "Visit new places" (8.8\%), and "Seek intellectual enrichment" (6.3\%). But this discovery has limitations. Since the travel motivation option on the questionnaire only provided 12 choices and was a single choice, the results of this study excluded other possible tourism motives and multiple motivations.

Jang and Wu (2006) studied the motivation of elderly tourists in Taiwan by using the pushpull dynamic factor model. According to existing research on senior tourists' motivations in developed societies, they designed questionnaires that required respondents to evaluate the importance of tourist motivation, which includes 23 push items and 12 pull items. 3 pull factors and 5 push factors are produced by the analysis of the 35 items. "Knowledge seeking" and "ego-enhancement" have become the two most important factors in stimulating Taiwan senior tourists among the five potential push factors. "cleanliness \& safety" was the most important factor among the three pull factors for attracting Taiwan senior tourists to travel destinations. However, because the participants in this study are all elderly people who attended the continuing education courses, their uniqueness may lead to bias and the results of the study cannot be applied to all senior tourists in Taiwan.

According to the grounded theory method, Hsu, Cai, \& Wong (2007) discussed the eight propositions proposed by reference to the existing tourism motivation literature and summarized the tourism motivation model of Chinese senior tourists. This model is divided into two components, external conditions, and internal desires. The external conditions consist of four conditions: social progress, health, time, and personal finance. The internal desires are divided into eight categories. They are improving well-being, seeking knowledge, escaping daily life, pride and patriotism, socializing, nostalgia and personal rewards. With the progress of Chinese society, the quality of citizen's life has been greatly improved, which has greatly increased the motivation for people to travel. The time and finances of elderly people also have a great impact on the motivation for travel. For elderly people, they have age specificity. Health is a prerequisite for their ability to travel. Improving physical and 
mental health, discovering changes in the country, learning, rewarding for their hard work in the past, and nostalgia are the motivations of Chinese elderly tourists.

The motivations of elderly tourists who come from developed countries and developing countries are very different. As the tourism motivation model is based on developed society and the development of western culture, the existing tourism motivation model may not be applicable when analysing the motivations of the senior tourists in developing countries and non-western societies. Therefore, when studying the tourism motivation of the senior tourists in China, the role played by the elderly in Chinese society, their social status, and the non-western cultural background of the senior tourists in China should be fully considered, so as to apply the new tourism motivation model to make the conclusion more accurate. For example, when using the western tourist motivation model, Guinn (1980) observed the motivations of Texas senior tourists include "rest and relaxation, social interaction, physical exercise, learning experience, self-fulfilment, accomplishment". However, many studies have found that older people in China have different motivations for traveling and are growing with the progress of society. The age of 55-70 groups directly involved in China's economic reform and opening up period. They had experienced the times when people's living standards were not high, education resources were scarce. At the current time, people's living standards have improved significantly, most of the people in the society had been lifted out of poverty, so they were more likely to accept social and cultural changes, and their ideas were easier to change. In addition, the family relations and economic relations between the elderly and their children are unique in Chinese culture, which makes the difference between the tourism motivation model of the elderly in China and the existing tourism motivation model based on developed countries and western cultures (Hsu, et al. 2007). According to the proposed Chinese senior tourism motivation model, the motivation of the Chinese elderly tourists including "rest and relax", "view the historic sites or beautiful scenery", "social contact", "improving the physical and mental health", "learning", "reward", and "nostalgia" (Huang, et al. 2003, Hsu, et al. 2007). 
This content is unavailable.

Please consult the

print version for access.

Figure2.1 A model of senior tourism motivations-Anecdotes from Beijing and Shanghai. Sources: Hsu, C. H. C., Cai, L. A., \& Wong, K. K. F. (2007).

\subsubsection{Tourist satisfaction}

Since there is no uniform definition of consumer satisfaction, Giese (1989) reviewed the previous studies by summarizing three previous aspects of consumer satisfaction definitions. "(1) consumer satisfaction is a response, an emotional or cognitive judgment (the emotional response predominating); (2) the response refers to a specific focus (the object of the consumer satisfaction); (3) The response is linked to a particular moment (prior to purchase, after purchase, after consumption, etc.)." Giese believed that considering the above aspects, consumer satisfaction has different definitions in different situations. 
For consumer satisfaction, the majority of people accept the expectations model has disconfirmation (Moutinho, 1987, Tse \& Wilton, 1988, Spreng, ManKenzie, \& Olshavsky, 1996). This model considers satisfaction as the differentiation between performance perceptions and expectations, and consumers will satisfy as long as performance surpasses expectations. Wang, Liu, \& Zhang (2010) cites Beard and Ragheb who states also emphasizes that visitor satisfaction is according to comparing visitors' actual experiences with previous expectations. Furthermore, Tribe, \& Snaith (1998) explained that tourist satisfaction also means how well could the travel experience meet people's travel needs and expectations in the journey. Kozak and Rimmington (2000) have studied a few conceptual and empirical literature on tourist satisfaction. They covered different areas such as tour guides, specific tours, travel agencies, restaurants, entertainment facilities, hotels and destinations. In addition, they also mentioned some research conducted at specific destinations, which measures tourist satisfaction by using different methods.

Because of the special nature of tourism, in most cases, visitors prefer to experience diversity such as going to a new destination. Although the satisfaction of visitors to the destination doesn't ensure their return (Bigne, Sanchez and Sanchez, 2001), the satisfaction of visitors to the destination will have impacts on their recommendations positively. Their findings indicate that as the satisfaction of visitors to the destination becomes higher, they are more tending to recommend it to friends. In other words, tourist satisfaction affects the motivation of other tourists positively.

Kim, Woo, and Uysal (2015) studied six important factors: "involvement, perceived value, satisfaction with the trip experience, leisure life satisfaction, the overall quality of life, and revisit intention". They found the six factors affect the behaviour and quality of life of elderly tourists significantly. With the measurement model, researchers confirmed that the travel experience will affect senior people's travel satisfaction, and the travel satisfaction will affect senior people's happiness and the quality of their life after retirement significantly, which also relates to senior people's health. Kim, Woo, and Uysal (2015) also found the participation of senior tourists in the process of travel will affect the perceived value of travel experience positively, which is the basic factor that determines the satisfaction of travel experience of the elderly. In terms of perception, gender and age have 
also been found to have an impact on human vulnerability (Boakye, 2012). For example, older people are more concerned about safety than young people. They will pay more attention to personal safety and avoid some potential dangers. Women are more vulnerable than men in terms of gender impact (Boakye, 2008).

Quality could be seen as the gap between expectations and perception of customer (Parasuraman, Zeithaml, \& Berry, 1990). The quality of tourism is affected by the expectations of tourists since the tour quality is the consequence of comparisons between tourist expectation and perception of tourism service (Lee, Jeon, \& Kim, 2010). Studies have shown that tourism expectations have a negative influence on tourism quality. As the expectation of tourists on tourism becomes higher, they tend to think that the quality of tourism is low. Quality is an antecedent to satisfaction. It can affect future behavioural intention through affecting satisfaction. Therefore, improvement of tourism quality is an important way for the increase in tourist satisfaction (Bigné, Sánchez, \& Sánchez, 2001).

Based on the Korean tourist satisfaction structure model, Lee, Jeon, \& Kim (2010) analyses the factors related to tourist satisfaction and obtains the following conclusions: Tourists' expectations affect tourism quality negatively. The motivation of tourists affects the tour quality positively. The expectation and motivation of tourist are interrelated. Tourism quality affect tourists' satisfaction positively. For tourist satisfaction, tourist expectation plays a very important role. On the one hand, when performance is more than expected, it usually gets emotional satisfaction. On the other hand, the consequence is usually emotional dissatisfaction when the expectation exceeds performance. Lee, Jeon, \& Kim (2010) demonstrate the applicability of this tourist satisfaction model to Chinese tourists who travel to South Korea. However, for local tourists in China, the application of this model is not certain. This study will refer to these conclusions when establishing the conceptual framework and verify its applicability.

When studied the behaviour of Taiwan's senior tourists, Huang and Tsai (2003) discovered that tourism-related services and hospitality services are the most important dimensions of senior tourist satisfaction. Among the tourism-related service dimensions, the five most important factors are "good shopping facilities, fascinating scenery, convenient 
transportation, and entertainment facilities, quality food and beverages, and quality accommodation". In the tourism personnel service dimension, "convenient customs, immigration and quarantine procedures, quality air services, quality tourism leaders and tour guide services, and quality travel agency services" account for a very important proportion. However, there is a geographical limitation. Since the participants of the research are all elderly people in Taiwan, the results of the study cannot determine whether it is applicable to all Chinese elderly people.

\subsection{Conceptual framework}

According to a review of articles, the conceptual framework for tourism motivation and satisfaction of Chinese senior tourists on day trips is built for this research. This model is designed for determinate the factors affect the tourist motivation and satisfaction, and confirm the causal relationship among tourist motivation, tourism expectation, tour quality, tourist satisfaction, and tourist future behavioural intention.

As mentioned before, motivation is a need that drives people to participate in some activities. As long as individuals want to meet their needs, their motivations will emerge. This indicates that people will be driven by tourist motivation to participate in trips. During the trips, when the tourist's tourism motivation is satisfied and the travel experience meets their tourism expectations, the tourist's assessment of the tour quality will be satisfied. Conversely, when travel does not satisfy the tourist's motivations, their perception of tour quality becomes unsatisfactory. Therefore, tourism motivation can be seen as a determinant of tour quality. Therefore, below is the proposed hypothesis:

H1: Tourism motivation has a positive effect on tourism quality.

The Expectation Disconfirmation Paradigm (EDP) believes that satisfaction or dissatisfaction of consumer is a function of the uncertainty caused by differences between actual performance and previous expectations. Higher performance than expected leads to satisfaction, but lower performance leads to dissatisfaction (Weber, 1997). The satisfaction will be higher than the perceived quality when the perceived value is more than 
expectations. Therefore, when tourists' tourism expectations are high, their perception of tour quality is more likely to be less satisfied. Therefore, below is the proposed hypothesis:

H2: Tourism expectations affect tour quality negatively.

Quality of service is elusive and abstract due to its characters, which are inseparability, intangibility, and heterogeneity (Parasuraman et al., 1985). However, the quality of corporate's services is recommended to measure consumer perceptions of quality. Therefore, perceived quality can be seen as the judgment of consumer of the overall quality of the tourism organization (Zeithaml, 1987). Better consumer satisfaction can be led by a higher perception of service quality. The service quality is a prerequisite for consumer satisfaction (Cronin and Taylor, 1992). Tourist satisfaction is the experience quality obtained after the travel experience (Baker and Crompton, 2000). Therefore, below is the proposed hypothesis:

H3: Tour quality affects tourist satisfaction positively.

Landon (1980) believes that consumer dissatisfaction is a determinant of complaint behaviours and also will be expressed by their behaviours. Therefore, in the consumer complaints behaviour study, it is usually believed that a portion of complaints must be the result of consumer dissatisfaction (Day \& Landon, 1977). Baker \& Crompton (2000) believe the satisfaction factor affects consumer complaints. Therefore, below is the proposed hypothesis:

H4: Tourist satisfaction has an impact on future behavioural intention.

In this model, push motivation and pull motivation are the two catalogues of tourist motivation. Objective factors and subjective are the two factors have an impact on tourist satisfaction. Subjective factors include tourism-related services and tourism employee services. Objective factors include weather conditions, traffic conditions, and destination conditions. 


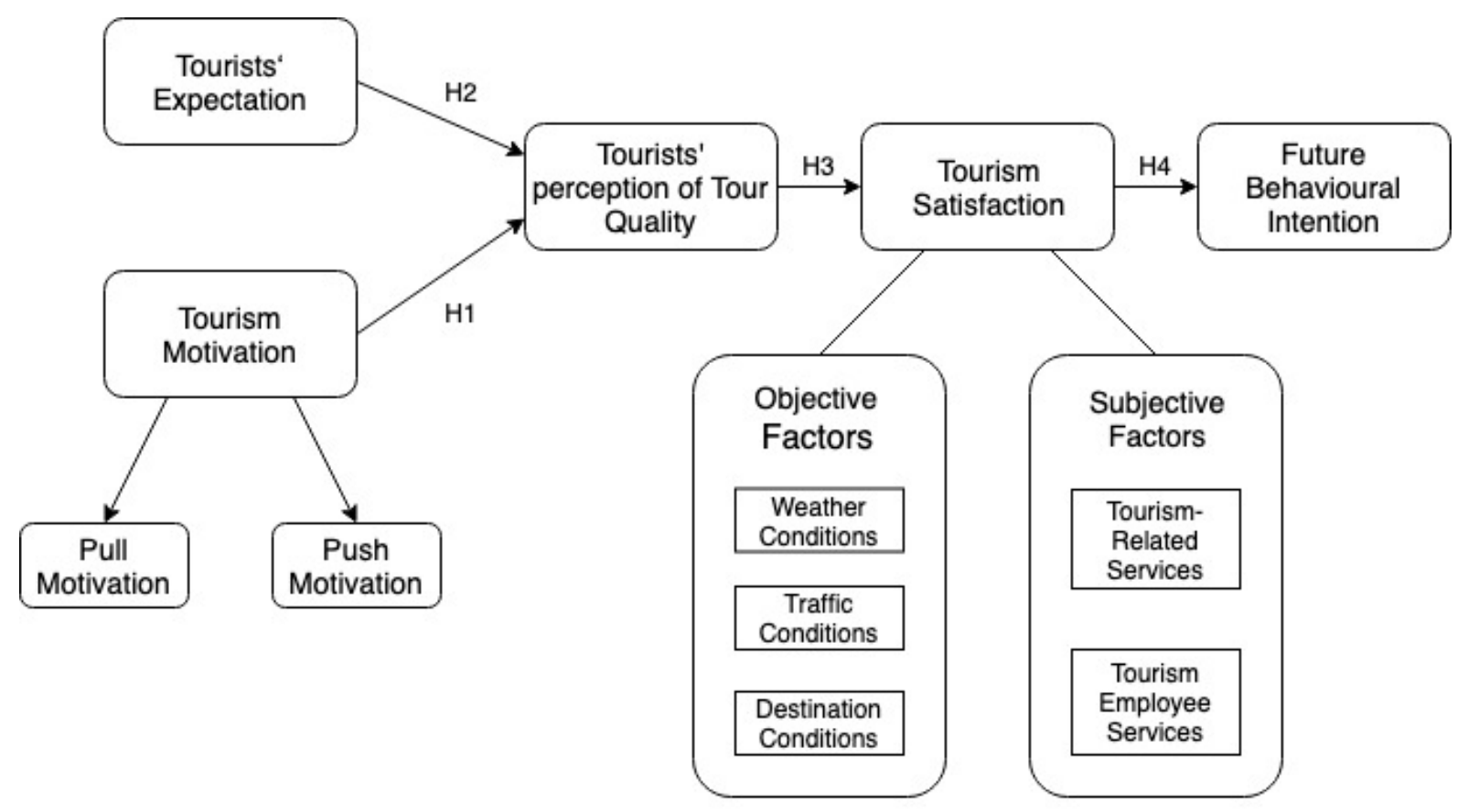

Figure2.2: The conceptual framework for tourist motivation and satisfaction of Chinese senior tourists on day trips

\subsection{Conclusion}

The senior tourism market is facing unprecedented opportunities. It is important to do research on the elderly tourist behaviours, considering the opportunities and challenges brought about by the expansion of this market. By improving the understanding of senior tourism, the tourism industry and government will better cope with the coming demographic challenges (Huber, d., Milne, s., \& Hyde, k. f., 2018). Exploring the senior tourism market cannot only better meet the increasing tourism consumption demands of the elderly population, but also could heighten senior people's life quality, make them live in a full and happy state of life, create job opportunities, improve the national economy, contribute to social stability, and fully reflect the country's civilization and social progress. 


\section{Chapter3 Research Methodology}

\subsection{Introduction}

The previous chapter presents an overview of the macro issues in the tourism market, such as the aging population, the senior tourism market status, and the global tourism market status, indicating senior tourism market importance and impacts on the tourism industry. However, as the previous chapter mentioned, the literature on the motivation and satisfaction of day trips of Chinese senior travellers is rare, even although there are many articles in this field. Therefore, determining senior tourist satisfaction and motivation through empirical research and creating a conceptual framework for senior tourist satisfaction and motivation on day trips become one of the most important objectives of this study.

The first purpose of this chapter is to introduce the research paradigm and methods adopted by the research to the readers and to justify the methods. The second purpose of this chapter is describing the execution of the fieldwork and to make the readers understand the process of empirical research, such as the research instruments adapted to collect data and data collection steps. The limitations of this study are discussed at the end of the chapter.

\subsection{Research philosophy and approach}

\subsubsection{Research philosophy}

Based on the success of the theory of natural sciences, social science developed a positivistic methodology, which is the foundation of social science empirical research. Positivists emphasize independence between the researched person and the researcher. Positivists will put forward hypotheses and require samplings selected randomly to collect data to show the falsity or truth of the hypotheses in the research process. (Easterby-Smith, 2008). Hypotheses should come from scientific theories, implement concepts through welldefined variables, and though confirming or falsifying assumptions to test them. The 
conclusion should link to the theory that forms the conceptual hypothesis framework. The argument points out that when the relationship among the empirical testing and theory is not clear, loyalty to scientific methodology will develop more comprehensive theories. Through the influence of this positivism, methodological education and empirical testing are still the core elements of social scientist training (Botterill, \& Platenkamp, 2012).

The characteristics of the study are consistent with the positivist paradigm. The researcher proposes four hypotheses according to the literature review and a conceptual framework, and then verify the proposed hypotheses and upgrades the proposed framework based on the data provided by anonymous questionnaires. Therefore, the paradigm chosen in this paper is positivism.

This paper chooses the quantitative research method from the positivist framework. Quantitative research usually converts into the application of statistical analysis to connect what is learned and what is known through the research. Collecting and analysing data through quantitative strategies needs descriptive statistics to understand the variable relationships. Application of descriptive statistics can infer numbers of population and estimate parameters for these populations (Trochim, 2006). Hypotheses, generalised from the selected sample to a population, and descriptive statistics are the foundation of Inferential statistics (Trochim, 2006). Quantitative analysis can obtain a visual representation of data by using charts, graphs, tables, and plots. The conclusions of the quantitative analysis come from logic, evidence, and argument (Trochim, 2006).

\subsubsection{Research instrument}

In this research, the questionnaire was used as the research instrument. Since the research proposes hypotheses that want to test, questionnaires are the most suitable instrument to collect the data. The researcher could be able to touch more population and get more data by with questionnaires. Generally, the answers obtained from questionnaires are standardized, which makes quantitative analysis easier and enables concreted results to be 
gained. In addition, using the questionnaire as the instrument can improve the research feasibility and reduce the cost since the field work of this research was conducted abroad.

The researcher designed the questionnaire used in this paper based on the understanding of the study of Huang and Tsai (2003), Hsu, Cai, and Wong (2007), Lee, Jeon, and Kim (2010) because their study has proved some tourism motivations and factors affecting tourist satisfaction. The questionnaire contained two sections. The first section was composed of questions about the participants' personal information (gender, age, education status, annual income, health status, etc.). This section presents a conspectus of the demographic characteristics of the participants. The second section is regarding tourist motivation of participants and their tourist satisfaction. These questions include the reasons for the participants' travel, the factors affecting the travel, the factors affecting the participants' travel satisfaction, etc. The objective of this section is to understand the participants' tourism motivation and factors affecting the participants' tourism satisfaction and motivation. More importantly, the relationship between participants' tourist satisfaction, tourism motivation, travel quality, and participants' future behaviour should be determined.

The following table indicates all the questions in the questionnaire, the reason for the question designing and the hypothesis related to.

Table 3.1 Questionnaire design analysis

\begin{tabular}{|c|c|c|c|}
\hline Number & Question & Literature & Hypothesis \\
\hline 1 & What is your gender? & \multirow{6}{*}{$\begin{array}{l}\text { These questions } \\
\text { present an overview } \\
\text { of the demographic } \\
\text { characteristics of the } \\
\text { participants (Huang, } \\
\text { \& Tsai, 2003). }\end{array}$} & \multirow{6}{*}{$\begin{array}{l}\text { To evaluate sample } \\
\text { characteristics. }\end{array}$} \\
\hline 2 & What is your age? & & \\
\hline 3 & What is your education? & & \\
\hline 4 & What is your marital status? & & \\
\hline 5 & What is your annual income? & & \\
\hline 6 & $\begin{array}{l}\text { Please rate your health based } \\
\text { on your personal } \\
\text { circumstances. }\end{array}$ & & \\
\hline 7 & $\begin{array}{l}\text { Based on your personal } \\
\text { experience, please indicate the } \\
\text { level of importance of these } \\
\text { reason for your travel. If you }\end{array}$ & $\begin{array}{l}\text { The researcher list as } \\
\text { many options as } \\
\text { possible for this } \\
\text { question. These }\end{array}$ & $\begin{array}{l}\text { To determinate the } \\
\text { senior tourist } \\
\text { motivation. }\end{array}$ \\
\hline
\end{tabular}




\begin{tabular}{|c|c|c|c|}
\hline & $\begin{array}{l}\text { have any other reasons not } \\
\text { include in the table, please } \\
\text { write in the last } 5 \text { rows of the } \\
\text { table and rate it. } \\
\text { Share travel experiences with } \\
\text { friends and relatives. } \\
\text { Attend the cultural events. } \\
\text { The availability of a good } \\
\text { restaurant and delicious food. } \\
\text { Have someplace can buy things } \\
\text { on the trip. } \\
\text { Get a new experience. } \\
\text { I want to see the things that I } \\
\text { don't normally see. } \\
\text { There are some places I have } \\
\text { always wanted to visit. } \\
\text { I want to get a rest and relax. } \\
\text { I just want to slow down. } \\
\text { Meet friends and socialization. } \\
\text { Visit relatives. } \\
\text { Satisfy curiosity. } \\
\text { A reward for your previous } \\
\text { hard work. } \\
\text { Nostalgic. } \\
\text { Fitness and physical exercise. } \\
\text { Special events and attractions } \\
\text { (such as visit the Buddha, } \\
\text { praying, etc.). } \\
\text { Outstanding scenery. } \\
\text { Historical sights. } \\
\text { Friends' recommendations. }\end{array}$ & $\begin{array}{l}\text { options are made } \\
\text { based on the } \\
\text { researcher's } \\
\text { understanding of } \\
\text { study of Huang and } \\
\text { Tsai (2003), Hsu, Cai, } \\
\text { and Wong (2007) and } \\
\text { Lee, Jeon, and Kim } \\
\text { (2010). } \\
\text { In order to make the } \\
\text { travel motivation } \\
\text { module more } \\
\text { detailed and specific, } \\
\text { the researcher asked } \\
\text { the participants to } \\
\text { write their own } \\
\text { reasons if those } \\
\text { reasons didn't show } \\
\text { in the table. }\end{array}$ & \\
\hline 8 & $\begin{array}{l}\text { Please indicate the level of } \\
\text { importance of the following } \\
\text { factors that affect your travel } \\
\text { plan based on your personal } \\
\text { circumstances. If you are } \\
\text { affected by any other factors } \\
\text { not include in the table, please } \\
\text { write in the last } 5 \text { rows of the } \\
\text { table and rate it. } \\
\text { Personal Financials } \\
\text { Discretionary time } \\
\text { Health status } \\
\text { Season and weather conditions } \\
\text { Traffic condition }\end{array}$ & $\begin{array}{l}\text { The researcher list as } \\
\text { many options as } \\
\text { possible for this } \\
\text { question. These } \\
\text { options are made } \\
\text { based on the } \\
\text { researcher's } \\
\text { understanding of } \\
\text { study of Huang and } \\
\text { Tsai (2003) and study } \\
\text { of Hsu, Cai, and } \\
\text { Wong (2007). } \\
\text { In order to get more } \\
\text { factors that affect }\end{array}$ & $\begin{array}{l}\text { To determinate the } \\
\text { factors that affect } \\
\text { senior tourists' } \\
\text { motivation. } \\
\text { To prove the } \\
\text { hypothesis } 1 . \\
\text { H1: Tourism } \\
\text { motivation has a } \\
\text { positive effect on } \\
\text { tourism quality. }\end{array}$ \\
\hline
\end{tabular}




\begin{tabular}{|c|c|c|c|}
\hline & $\begin{array}{l}\text { Overall cost of travel (including } \\
\text { transportation and meals) }\end{array}$ & $\begin{array}{l}\text { participants' travel } \\
\text { plan, the researcher } \\
\text { asked the } \\
\text { participants to write } \\
\text { their own factors if } \\
\text { those factors didn't } \\
\text { show in the table. }\end{array}$ & \\
\hline 9 & $\begin{array}{l}\text { Please indicate the level of } \\
\text { importance of the following } \\
\text { factors that affect your travel } \\
\text { satisfaction based on your } \\
\text { personal circumstances. If you } \\
\text { are affected by any other } \\
\text { factors not include in the table, } \\
\text { please write in the last } 5 \text { rows } \\
\text { of the table and rate it. } \\
\text { Good shopping facilities } \\
\text { Attractive scenery } \\
\text { Quality of food and beverage } \\
\text { The level of participation in } \\
\text { activities during the trip } \\
\text { Convenient transport } \\
\text { Weather conditions } \\
\text { Number of tourists in scenic } \\
\text { spots } \\
\text { Scenic reception capacity } \\
\text { Scenic security } \\
\text { Service quality of scenic } \\
\text { service personnel } \\
\text { Overall cost of travel (including } \\
\text { transportation and meals) }\end{array}$ & $\begin{array}{l}\text { The researcher list as } \\
\text { many options as } \\
\text { possible for this } \\
\text { question. These } \\
\text { options are made } \\
\text { based on the } \\
\text { researcher's } \\
\text { understanding of } \\
\text { study of Huang and } \\
\text { Tsai (2003). } \\
\text { In order to get more } \\
\text { factors that affect } \\
\text { participants' travel } \\
\text { satisfaction, the } \\
\text { researcher asked the } \\
\text { participants to write } \\
\text { their own factors if } \\
\text { those factors didn't } \\
\text { show in the table. }\end{array}$ & $\begin{array}{l}\text { To determinate the } \\
\text { factors that affect } \\
\text { senior tourists' } \\
\text { satisfaction. }\end{array}$ \\
\hline 10 & $\begin{array}{l}\text { What was the level of your } \\
\text { expectation of this tour? }\end{array}$ & $\begin{array}{l}\text { This question is made } \\
\text { based on the } \\
\text { researcher's } \\
\text { understanding of } \\
\text { study of Lee, Jeon, } \\
\text { and Kim (2010). } \\
\text { This question is } \\
\text { designed to get the } \\
\text { data of the } \\
\text { participant's tour } \\
\text { expectation level. }\end{array}$ & $\begin{array}{l}\text { To prove the } \\
\text { hypothesis } 2 \text {. } \\
\text { H2: Tourism } \\
\text { expectations affect } \\
\text { tour quality } \\
\text { negatively. }\end{array}$ \\
\hline 11 & $\begin{array}{l}\text { How was the quality of this } \\
\text { tour? }\end{array}$ & $\begin{array}{l}\text { This question is made } \\
\text { based on the } \\
\text { researcher's }\end{array}$ & $\begin{array}{l}\text { To prove the } \\
\text { hypothesis } 2 \text { and } \\
\text { hypothesis } 3 .\end{array}$ \\
\hline
\end{tabular}




\begin{tabular}{|c|c|c|c|}
\hline & & $\begin{array}{l}\text { understanding of } \\
\text { study of Lee, Jeon, } \\
\text { and Kim (2010). } \\
\text { This question is } \\
\text { designed to get the } \\
\text { data of the } \\
\text { participant's } \\
\text { perception of the } \\
\text { tour quality. }\end{array}$ & $\begin{array}{l}\text { H2: Tourism } \\
\text { expectations affect } \\
\text { tour quality } \\
\text { negatively. } \\
\text { H3: Tour quality } \\
\text { affects tourist } \\
\text { satisfaction } \\
\text { positively. }\end{array}$ \\
\hline 12 & $\begin{array}{l}\text { Were you satisfied with this } \\
\text { tour? }\end{array}$ & $\begin{array}{l}\text { This question is made } \\
\text { based on the } \\
\text { researcher's } \\
\text { understanding of } \\
\text { study of Huang and } \\
\text { Tsai (2003), Lee, } \\
\text { Jeon, and Kim (2010). } \\
\text { This question is } \\
\text { designed to get the } \\
\text { data of the } \\
\text { participant's } \\
\text { satisfaction level of } \\
\text { the tour. }\end{array}$ & $\begin{array}{l}\text { To prove the } \\
\text { hypothesis } 3 \text { and } \\
\text { hypothesis } 4 . \\
\text { H3: Tour quality } \\
\text { affects tourist } \\
\text { satisfaction } \\
\text { positively. } \\
\text { H4: Tourist } \\
\text { satisfaction has an } \\
\text { impact on future } \\
\text { behavioural } \\
\text { intention. }\end{array}$ \\
\hline 13 & $\begin{array}{l}\text { Would you recommend these } \\
\text { spots to others if you were } \\
\text { satisfied? }\end{array}$ & \multirow{2}{*}{$\begin{array}{l}\text { This question is made } \\
\text { based on the } \\
\text { researcher's } \\
\text { understanding of } \\
\text { study of Huang and } \\
\text { Tsai (2003), Lee, } \\
\text { Jeon, and Kim (2010). } \\
\text { This question is } \\
\text { designed to get the } \\
\text { data of the } \\
\text { participant's future } \\
\text { behavioural } \\
\text { intention. }\end{array}$} & \multirow[b]{2}{*}{$\begin{array}{l}\text { To prove the } \\
\text { hypothesis } 4 \text {. } \\
\text { H4: Tourist } \\
\text { satisfaction has an } \\
\text { impact on future } \\
\text { behavioural } \\
\text { intention. }\end{array}$} \\
\hline 14 & $\begin{array}{l}\text { Whether you would tell your } \\
\text { friends and relatives about the } \\
\text { unpleasant experience of this } \\
\text { trip if you were not satisfied? }\end{array}$ & & \\
\hline
\end{tabular}

\subsection{Research Process}

The research process is shown in the following table: 
Table 3.2 The research process

\begin{tabular}{|l|l|l|}
\hline $\begin{array}{l}\text { Part 1 } \\
\text { Developing } \\
\text { Research } \\
\text { Question }\end{array}$ & Literature review & $\begin{array}{l}\text { Identifying the research gap and the research } \\
\text { objectives }\end{array}$ \\
\cline { 2 - 3 } & $\begin{array}{l}\text { Getting the ethical } \\
\text { approval }\end{array}$ & To get permission to implement field work \\
\hline \multirow{2}{*}{$\begin{array}{l}\text { Part 2 } \\
\text { Data }\end{array}$} & $\begin{array}{l}\text { Phase 1 } \\
\text { Collection }\end{array}$ & $\begin{array}{l}\text { Phase } 2 \\
\text { Survey } \\
\text { To test sampling method and the questionnaire } \\
\text { To determine approximate completion time }\end{array}$ \\
\cline { 2 - 3 } & $\begin{array}{l}\text { Implementation } \\
\text { Part 3 }\end{array}$ & $\begin{array}{l}\text { To collect data } \\
\text { To investigate the senior tourists' motivation and } \\
\text { satisfaction in day trips }\end{array}$ \\
\hline Data Analysis & $\begin{array}{l}\text { analysis with data } \\
\text { from } \\
\text { questionnaires }\end{array}$ & $\begin{array}{l}\text { To get answer for the research question } \\
\text { To achieve the research objectives }\end{array}$ \\
\hline
\end{tabular}

\subsubsection{Sampling method}

Volunteer sampling of non-random sampling is used in this study. Non-random samples are simply samples which are not extracted in a random pattern. Applicable to researchers to select samples for defined purposes in the study (O'Leary, 2017).

This study requires participants with specific demographic characteristics because of the research concept. First, participants must be over 50 years old. According to China's previous retirement policy, the retirement age of Chinese female is 50-55 and the retirement age of Chinese male is 60 (The National People's Congress of the People's Republic of China, 1978a, 1978b). Therefore, this study is aimed at older people over the age of 50. Second, participants must be Beijing residents. Third, participants must have had day trips experience within two years. Random sampling will take a lot of time and couldn't accurately target eligible participants, while non-random samples allow researchers to accurately find samples that meet the criteria. Therefore, in order to obtain more accurate research data, non-random sampling is selected for use, although it has the limitations which will discuss later. 
To locate the participants in a limited time, this research received cooperation and assistance of a senior association of local university in Beijing, whose members are composed of retirees of the university and basically organize day trips in and around Beijing every year for their members. According to China's previous retirement policy (The National People's Congress of the People's Republic of China, 1978a, 1978b), the members of this association met the criteria for the target population of this study. In order to involve more kinds of occupations, the study sample also included some randomly selected local residents.

\subsubsection{Pilot testing}

The objective of the pilot test is to identify participants' comprehension of the questionnaire and the weaknesses of the questionnaire. It tests various parts of the questionnaire, such as approximate completion time, clarity of questions and wording. The pilot test was conducted after receiving Human Ethics approval from Victoria University of Wellington.

The pilot test was conducted on $29^{\text {th }}$ November 2018. Participants are six volunteers who meet the criteria. Participation information handouts and questionnaires were all distributed to volunteers. After finished the questionnaire, the participants would be asked if they have any issues during the questionnaire filling process and if it is understandable and easy to complete.

According to the pilot testing feedback, the researcher modified the questionnaire. First, it is emphasized that the questions are the single choice and each question needs to be answered. Second, change the question description more understandable. Third, because of the old policy in China, the senior people who have received undergraduate education do not get a bachelor's degree. Therefore, in the options of the question about educational level, the bachelor's degree is changed to the undergraduate. 
The second test conducted after the questionnaire has changed, and the feedback was good. Therefore, the final questionnaires were printed and distributed to the participants on $10^{\text {th }}$ December, 2018, and $25^{\text {th }}$ December, 2018.

\subsubsection{Main survey}

The questionnaires were distributed to the neighbourhood on $10^{\text {th }}$ December, 2018 , and members of the senior association of a university in Beijing on $25^{\text {th }}$ December, 2018. 80 questionnaires had distributed on $10^{\text {th }}$ December 2018 , and 43 had collected, the response rate is $53.75 \% .130$ questionnaires had distributed on $25^{\text {th }}$ December 2018 , and 122 had collected, the response rate is $93.85 \%$. Therefore, 210 questionnaires had distributed and 165 had collected, with a total response rate of $78.57 \%$.

\subsection{Human ethics approval}

Victoria University of Wellington requires that all University human research have to obtain human ethics approval. The purpose of Human Ethics Policy is to ensure all University human research comply with high ethical standards (Victoria University of Wellington, 2018, Human Ethics Policy).

This research obtained Human Ethics approval on $26^{\text {th }}$ November, 2018, before fieldwork began. The HEC reference number of this research is 0000026937.

\subsection{Analysis method used for quantitative data}

\subsubsection{Reliability}

The consistency among multiple measurements of the variable is evaluated by Reliability. Reliability usually measures with internal consistency. It can be applied for the consistency between variables in a summary scale. The various indicators should measure the same structure, which is the basic rationale of internal consistency. Therefore, they are highly intercorrelated (Hair, Black, Babin, \& Anderson, 2013). 
Generally, the reliability coefficient is used as a measurement of internal coefficient, and the most widely used is Cronbach's alpha (Cortina \& Schmitt, 1993). Having a value of 0.7 or higher of Cronbach's alpha is generally considered acceptable (Hair, Black, Babin, \& Anderson, 2013).

The three variables (the tourism motivation of senior visitors, the factors influence tourism motivation, and the factors influence their tourist satisfaction) are all have multiple measurements in this study. Therefore, a reliability analysis of these three variables is required to measure their internal consistency.

\subsubsection{Descriptive statistics}

The descriptive statistic is a process of analysing statistical data, which is used to describe or summarize the characteristics of a set of information quantitatively (Mann, 2010). Descriptive statistical analysis includes multivariate analysis, bivariate analysis, and univariate analysis (Babbie, 2013).

In quantitative analysis, univariate analysis is simpler than others. It describes a case by analysing values such as frequency distribution, mean and discrete measures. Bivariate analysis analyses two variables simultaneously to identify the two variables relationship. (Babbie, 2013).

Therefore, the univariate analysis concentrates on describing the items of analysis in the research, while the bivariate analysis attaches more importance to analyse variables and empirical relationships between them (Babbie, 2013).

In this research, participants' gender, age, education, annual income, and health status were descriptive analysis to make the reader aware the characteristics of the research samples. 


\subsubsection{Factor analysis}

Defining the basic structure between variables in the analysis is the factor analysis main objective. According to the correlation between variables, the variables are classified and combined to form new variable groups though factor analysis (Babbie, 2013).

In factor analysis, researchers typically do not perform factor analysis on samples with less than 50 observations. A sample size of more than 100 observations is preferred. The general rule is that the minimum sample size is at least five times the number of variables that need to be analysed. (Babbie, 2013). The sample size of this research adheres to the criteria recommended for factor analysis.

The three variables (the tourism motivation of senior visitors, the factors influence tourism motivation, and the factors influence their tourist satisfaction) need to use the factor analysis in this study. Factor analysis can classify multiple motivations and indicate some motives that play an important role. Similarly, factor analysis will be used for factors influence tourism motivation and factors influence tourist satisfaction. This can raise awareness of these variables and enrich the conceptual framework previously proposed.

\subsubsection{Correlation analysis and regression analysis}

The Pearson correlation coefficient is a statistical analysis indicator representing the degree and the relevant direction of correlation between the two variables. Technically, it is called Pearson's product moment correlation coefficient (Blaikie, 2003).

The standardizing the covariance produces the Pearson correlation coefficient. The Pearson correlation coefficient value can be any value between -1 and $+1 .-1$ indicates the significant negative correlation, 0 indicates no relationship between the two variables, and +1 indicates the significant positive relationship between the two variables (Hair, Black, Babin, \& Anderson, 2013). Cohen (1988) proposed a Pearson's $r$ rule in which a coefficient of 0.5 or greater can be considered "large", 0.3 can be considered "medium", 0.1 can be considered "small" (Blaikie, 2003). 
Regression analysis is a data analysis method that represents the relationship between variables in the form of regression equations. Linear regression analysis is a statistical analysis form for finding the linear equation which can best describe the relationship between two variables (Babbie, 2013).

In linear regression analysis, the regression model can clearly indicate the existence or approximate perfect linear correlation between two variables. Linear regression models have significant descriptive and inferential value. The regression line provides a graphical representation of the association between two variables, and the regression equation summaries the effective forms of the association. If the equation correctly describes the general correlation between two variables, other sets of values can also use it to predict (Babbie, 2013).

In order to verify the research hypothesis, the research can also use standard multiple regression, because each independent variable can use its prediction of the dependent variable to evaluate its own value in the standard model (Tabachnick and Fidell, 2013).

This research can examine the relationship among tourist motivation, tourism expectation, tour quality, tourist satisfaction, and tourists' future behavioural intention by the correlation and regression analysis, and verify the correctness of the four hypotheses proposed previously, which are:

H1: Tourism motivation has a positive effect on tourism quality.

$\mathrm{H} 2$ : Tourism expectations affect tour quality negatively.

H3: Tour quality affects tourist satisfaction positively.

H4: Tourist satisfaction has an impact on future behavioural intention.

\subsection{Research limitations}

The questionnaire for this study is carefully designed and the pre-tests are conducted. Most participants in this research have a good education level, and all participants have day trips experience within two years, which met the criteria. The response rate is good. 
However, there are still some limitations. First, volunteer sampling survey is adopted in this study. Most participants are university retirees who are high-qualified people and can represent educated, informed citizens, which means they can represent a part of the society but not the society of all. The probability sampling method can be used in future research. Second, due to limited resources, the number of research samples is small. In future studies, the sample size should be increased in order to strengthen credibility of the research findings. Third, the survey was conducted in China, all were undertaken in Chinese. Problems may arise when translating the research question from English to Chinese. Conducting research in multiple languages may express or achieve different realities, and translation from one language to another can lead to slight differences in meaning (Kapborg, \& Bertero, 2001).

\subsection{Conclusion}

This chapter introduces the research methods of this study. The questionnaire survey method was carefully selected by the researcher after reviewing relevant literature and determining research objectives. The researcher grew up in Beijing, China, so Beijing is the most suitable place for this questionnaire survey, which will make the survey easier to conduct. For the questionnaire survey can bring more samples, it is an appropriate method for this research. More data could be collected from more samples, which may lead to more precise results for the research question. The questionnaire contains all the variables required by the research objectives, such as seniors' tourism motivation, factors affecting seniors' tourism motivation and satisfaction, and future behavioural intention of senior tourists. Despite the limitations, the researcher was able to achieve the research objectives by analysing the data and modifying the proposed conceptual framework.

The following chapters will present the analysis and discussion of data, as well as some suggestions put forward by the researcher. 


\section{Chapter 4 Data Analysis}

\subsection{Introduction}

This chapter presents the results of the data analysis. The purpose of this chapter is to achieve the research goals of the paper through data analysis results. First, trying to determine the tourism motivation of day trips for Chinese senior tourists, the factors that influence their tourism motivation and the factors that influence their tourist satisfaction. Second, trying to prove the four hypotheses that were proposed in the previous chapters.

\subsection{The questionnaire result}

210 questionnaires had distributed and 165 had collected, with a total response rate of 78.57\%. Six of the questionnaires are unclear or have not filled questions, which are classified as invalid questionnaires. Therefore, there are 159 valid questionnaires.

\subsubsection{Participant demographic characteristics}

In terms of genders, the number of participants was not very balanced, with $69.81 \%$ of men and $30.19 \%$ of women (Table 4.1 ), and the quantity of male participants was greater than that of female participants. This is a difference between this study and other studies. Regarding the age, the larger group was participants over 70 years old $(36.48 \%)$, followed by participants aged 66-70 (23.90\%), 61-65 participants (20.13\%). The number of participants aged $50-55$ is the lowest, at only $7.54 \%$ (Table 4.1 ). In terms of education level, the less than undergraduate group accounted for $39.62 \%$, and most of the participants were undergraduate and above (Table 4.1). This may be because the university retirees in the sample occupy a larger proportion. Most of the participants are married (93.08\%). Regarding the annual income, the majority of the participants' annual income is 50,001 200,000 CNY (79.25\%), which is about 10,870-43,478 NZD. Among them, Participants with an annual income of 50,001-100,000 CNY (10,870-21,739NZD) account for $37.11 \%$, and Participants with an annual income of $1000,001-200,000$ CNY $(21,740-43,478 N Z D)$ account for $42.14 \%$ (Table 4.1). NZD to CNY is based on exchange rate 4.6 in this research. Regarding 
the health of the participants, only $1.88 \%$ of participants thought they were unhealthy. Most participants considered their health to be normal (38.37\%), or healthy $(50.32 \%)$, or even very healthy $(9.43 \%)$ (Table 4.1$)$.

Table 4.1 The demographic characteristics of the participants

\begin{tabular}{|c|c|c|c|}
\hline \multicolumn{2}{|c|}{ Demographic characteristics } & Number of participants & Percentage (\%) \\
\hline \multirow{3}{*}{ Gender } & Male & 111 & 69.81 \\
\hline & Female & 48 & 30.19 \\
\hline & Total & 159 & 100 \\
\hline \multirow{6}{*}{ Age } & $50-55$ years old & 12 & 7.54 \\
\hline & $56-60$ years old & 19 & 11.95 \\
\hline & $61-65$ years old & 32 & 20.13 \\
\hline & $66-70$ years old & 38 & 23.90 \\
\hline & over 70 years old & 58 & 36.48 \\
\hline & Total & 159 & 100 \\
\hline \multirow{5}{*}{ Education } & Less than undergraduate & 63 & 39.62 \\
\hline & Undergraduate & 85 & 53.46 \\
\hline & Master's Degree & 9 & 5.66 \\
\hline & Doctorate, PhD., DSc & 2 & 1.26 \\
\hline & Total & 159 & 100 \\
\hline \multirow{5}{*}{ Marital status } & Single & 1 & 0.63 \\
\hline & Married & 148 & 93.08 \\
\hline & Widowed & 9 & 5.66 \\
\hline & Divorce & 1 & 0.63 \\
\hline & Total & 159 & 100 \\
\hline \multirow{6}{*}{ Annual income } & Less than $50,000 \mathrm{CNY}$ & 30 & 18.87 \\
\hline & $50,001-100,000 \mathrm{CNY}$ & 59 & 37.11 \\
\hline & $1000,001-200,000 \mathrm{CNY}$ & 67 & 42.14 \\
\hline & $200,001-300,000$ CNY & 3 & 1.88 \\
\hline & Over than $300,001 \mathrm{CNY}$ & 0 & 0 \\
\hline & Total & 159 & 100 \\
\hline \multirow{2}{*}{ Health status } & Unhealthy at all & 0 & 0 \\
\hline & Unhealthy & 3 & 1.88 \\
\hline
\end{tabular}




\begin{tabular}{|c|c|c|c|}
\hline & Normal & 61 & 38.37 \\
\cline { 2 - 4 } & Healthy & 80 & 50.32 \\
\cline { 2 - 4 } & Very healthy & 15 & 9.43 \\
\cline { 2 - 4 } & Total & 159 & 100 \\
\hline
\end{tabular}

\subsubsection{Results of tourism-related questions}

The measurement results include the following 41 items (Table 4.2): tourism motivation (19 items), factors affecting tourism motivation (6 items), factors affecting tourist satisfaction (11 items), tourism expectation ( 1 item), tour quality (1 item), tourist satisfaction (1 item) and tourist future behavioural intention ( 2 items). These items were scored on a five-level Likert scale, depending on whether the respondent agreed or disagreed with each statement. Table 4.3 shows the number of the participants $(N)$, and the mean value of each item (Mean).

Table 4.2 Items for variables

\begin{tabular}{|l|l|}
\hline Variables & \\
\hline \multirow{5}{*}{ Tourism } & Share travel experiences with friends and relatives. (TM1) \\
\cline { 2 - 3 } motivation & Attend the cultural events. (TM2) \\
\cline { 2 - 3 } & The availability of a good restaurant and delicious food. (TM3) \\
\cline { 2 - 3 } & Have someplace can buy things on the trip. (TM4) \\
\cline { 2 - 3 } & I I wet a new experience. (TM5) \\
\cline { 2 - 3 } & I want to see the things that I don't normally see. (TM6) \\
\cline { 2 - 3 } & I just want to slow down. (TM9) \\
\cline { 2 - 3 } & Meet friends and socialization. (TM10) \\
\cline { 2 - 3 } & Visit relatives. (TM11) \\
\cline { 2 - 3 } & Satisfy curiosity. (TM12) \\
\cline { 2 - 3 } & A reward for your previous hard work. (TM13) \\
\cline { 2 - 3 } & Nostalgic. (TM14) \\
\cline { 2 - 3 } & Fitness and physical exercise. (TM15) \\
\hline
\end{tabular}




\begin{tabular}{|c|c|}
\hline & $\begin{array}{l}\text { Special events and attractions (such as visit the Buddha, praying, etc.). } \\
\text { (TM16) }\end{array}$ \\
\hline & Outstanding scenery. (TM17) \\
\hline & Historical sights. (TM18) \\
\hline & Friends' recommendations. (TM19) \\
\hline \multirow{6}{*}{$\begin{array}{l}\text { Influencing } \\
\text { factor of } \\
\text { tourism } \\
\text { motivation }\end{array}$} & Personal Financials [IF(TM)1] \\
\hline & Discretionary time [IF(TM)2] \\
\hline & Health status [IF(TM)3] \\
\hline & Season and weather conditions [IF(TM)4] \\
\hline & Traffic condition [IF(TM)5] \\
\hline & Overall cost of travel (including transportation and meals) [IF(TM)6] \\
\hline \multirow{11}{*}{$\begin{array}{l}\text { Influencing } \\
\text { factor of } \\
\text { tourist } \\
\text { satisfaction }\end{array}$} & Good shopping facilities [IF(TS)1] \\
\hline & Attractive scenery [IF(TS)2] \\
\hline & Quality of food and beverage [IF(TS)3] \\
\hline & The level of participation in activities during the trip [IF(TS)4] \\
\hline & Convenient transport [IF(TS)5] \\
\hline & Weather conditions [IF(TS)6] \\
\hline & Number of tourists in scenic spots [IF(TS)7] \\
\hline & Scenic reception capacity [IF(TS)8] \\
\hline & Scenic security [IF(TS)9] \\
\hline & Service quality of scenic service personnel [IF(TS)10] \\
\hline & Overall cost of travel (including transportation and meals) [IF(TS)11] \\
\hline $\begin{array}{l}\text { Tourism } \\
\text { expectation }\end{array}$ & The level of the participant' expectation of the trip (TE) \\
\hline $\begin{array}{l}\text { Tour } \\
\text { quality }\end{array}$ & The quality of the tour (TQ) \\
\hline $\begin{array}{c}\text { Tourist } \\
\text { satisfaction }\end{array}$ & The level of the participant' satisfaction of the trip (TS) \\
\hline \multirow{2}{*}{$\begin{array}{c}\text { Future } \\
\text { behavioural } \\
\text { intention }\end{array}$} & $\begin{array}{l}\text { If the participant is satisfied with the trip, will they recommend it to others? } \\
\text { (FB1) }\end{array}$ \\
\hline & $\begin{array}{l}\text { If the participant is not satisfied with the trip, will they complain to others? } \\
\text { (FB2) }\end{array}$ \\
\hline
\end{tabular}


Table 4.3 Results of tourism-related questions

\begin{tabular}{|c|c|c|c|c|c|c|}
\hline & Items & $\mathrm{N}$ & Mean & Items & $\mathrm{N}$ & Mean \\
\hline \multirow{12}{*}{$\begin{array}{c}\text { Tourism } \\
\text { motivation } \\
\text { (Push) }\end{array}$} & TM7 & 159 & 4.19 & IF(TM)3 & 159 & 4.28 \\
\hline & TM6 & 159 & 4.08 & IF(TM)5 & 159 & 4.12 \\
\hline & TM1 & 159 & 3.68 & IF(TM)4 & 159 & 4.06 \\
\hline & TM5 & 159 & 3.52 & IF(TM)6 & 159 & 4.04 \\
\hline & TM12 & 159 & 3.52 & IF(TM)1 & 159 & 3.92 \\
\hline & TM8 & 159 & 3.43 & IF(TM)2 & 159 & 3.48 \\
\hline & TM2 & 159 & 3.42 & IF(TS)9 & 159 & 4.48 \\
\hline & TM10 & 159 & 3.16 & IF(TS)2 & 159 & 4.44 \\
\hline & TM9 & 159 & 3.09 & IF(TS)10 & 159 & 4.40 \\
\hline & TM14 & 159 & 3.07 & IF(TS)6 & 159 & 4.31 \\
\hline & TM11 & 159 & 3.03 & IF(TS)5 & 159 & 4.28 \\
\hline & TM16 & 159 & 2.68 & IF(TS)3 & 159 & 4.27 \\
\hline \multirow{10}{*}{$\begin{array}{c}\text { Tourism } \\
\text { motivation } \\
\text { (Pull) }\end{array}$} & TM17 & 159 & 4.37 & IF(TS)11 & 159 & 4.13 \\
\hline & TM18 & 159 & 4.23 & IF(TS)8 & 159 & 4.12 \\
\hline & TM3 & 159 & 3.91 & IF(TS)7 & 159 & 3.65 \\
\hline & TM15 & 159 & 3.75 & IF(TS)4 & 159 & 3.48 \\
\hline & TM19 & 159 & 3.55 & IF(TS)1 & 159 & 3.33 \\
\hline & TM4 & 159 & 2.97 & FB2 & 159 & 1.21 \\
\hline & TM13 & 159 & 2.91 & FB1 & 159 & 1.04 \\
\hline & $\mathrm{TE}$ & 159 & 4.03 & & & \\
\hline & TQ & 159 & 3.74 & & & \\
\hline & TS & 159 & 3.81 & & & \\
\hline
\end{tabular}

\subsection{Tourism motivation}

Reliability analysis and confirmatory factor analysis was conducted for tourism motivation.

\subsubsection{Tourism push motivation}

The reliability of tourism push motivation was good (Cronbach's Alpha $=0.875>0.7$ ) (Table 4.4). This shows that the internal consistency between the 12 items of tourism push 
motivation is high. Meanwhile, the scale passes the KMO and Bartlett's Test $(\mathrm{KMO}=0.881>0.5, \mathrm{Sig}=0.000<0.05)($ Table 4.5$)$. Therefore, tourism push motivation suitable to conduct factor analysis.

Table 4.4 The reliability of tourism push motivation

Cronbach's Alpha $\quad$ N of Items

875

12

Table 4.5 The KMO and Bartlett's test for tourism push motivation

\begin{tabular}{lll}
\hline Kaiser-Meyer-Olkin Measure of Sampling Adequacy. & .881 \\
Bartlett's Test of Sphericity & Approx. Chi-Square & 924.298 \\
& df & 66 \\
& Sig. & .000 \\
\hline
\end{tabular}

Table 4.6 shows that the first three factors extracted can explain $67.058 \%$. The scree plot shows that starting from the fourth factor, the subsequent factors have little difference in eigenvalues (Figure 4.1). Therefore, the first three factors are extracted.

Table 4.6 The total variance explanation for tourism push motivation

\begin{tabular}{|c|c|c|c|c|c|c|c|}
\hline \multirow[b]{2}{*}{ Component } & \multicolumn{3}{|c|}{ Initial Eigenvalues } & \multicolumn{3}{|c|}{$\begin{array}{c}\text { Extraction Sums of Squared } \\
\text { Loadings }\end{array}$} & \multirow{2}{*}{$\begin{array}{c}\text { Rotation } \\
\text { Sums of } \\
\text { Squared } \\
\text { Loadings }^{\text {a }} \\
\text { Total }\end{array}$} \\
\hline & Total & $\begin{array}{c}\% \text { of } \\
\text { Variance }\end{array}$ & Cumulative \% & Total & $\begin{array}{c}\% \text { of } \\
\text { Variance }\end{array}$ & Cumulative \% & \\
\hline 1 & 5.277 & 43.974 & 43.974 & 5.277 & 43.974 & 43.974 & 4.935 \\
\hline 2 & 1.975 & 16.457 & 60.431 & 1.975 & 16.457 & 60.431 & 2.605 \\
\hline 3 & .795 & 6.627 & 67.058 & .795 & 6.627 & 67.058 & 3.242 \\
\hline 4 & .690 & 5.746 & 72.804 & & & & \\
\hline 5 & .662 & 5.520 & 78.323 & & & & \\
\hline 6 & .544 & 4.532 & 82.855 & & & & \\
\hline 7 & .522 & 4.353 & 87.208 & & & & \\
\hline 8 & .432 & 3.601 & 90.809 & & & & \\
\hline 9 & .354 & 2.949 & 93.758 & & & & \\
\hline 10 & .314 & 2.616 & 96.374 & & & & \\
\hline 11 & .248 & 2.068 & 98.442 & & & & \\
\hline 12 & .187 & 1.558 & 100.000 & & & & \\
\hline
\end{tabular}




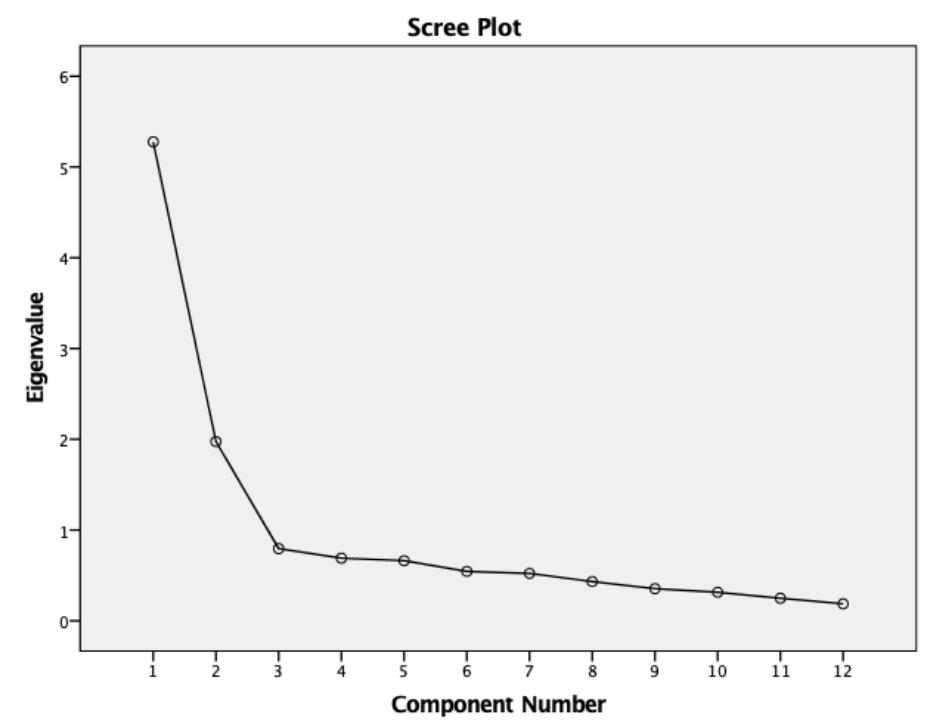

Figure 4.1 The scree plot for tourism push motivation

The structure matrix (Table 4.7) indicates that the factor loadings of TM1, TM8, TM9, TM10, TM11, TM14 are higher on factor1, the factor loadings of TM5, TM6, TM7, TM12 are higher on factor2, while the factor loadings of TM2, TM6 are higher on factor3. Therefore, factor 1 is named as "relaxation and sociality", factor 2 is named as "knowledge-seeking", and factor 3 is named as "intangible cultural need". Table 4.8 shows the mean of the three push factors.

Table 4.7 The structure matrix for tourism push motivation

\begin{tabular}{|l|l|l|l|}
\hline \multirow{2}{*}{} & \multicolumn{3}{|c|}{ Component } \\
\cline { 2 - 4 } & 1 & 2 & \multicolumn{1}{l|}{3} \\
\hline TM1 & .687 & .464 & .576 \\
\hline TM2 & .646 & .287 & .762 \\
\hline TM5 & .453 & .677 & .635 \\
\hline TM6 & .085 & .734 & .279 \\
\hline TM7 & -.064 & .753 & .163 \\
\hline TM8 & .774 & .115 & .535 \\
\hline TM9 & .823 & .154 & .521 \\
\hline TM10 & .878 & .225 & .523 \\
\hline TM11 & .883 & .189 & .398 \\
\hline TM12 & .347 & .741 & .111 \\
\hline TM14 & .833 & .124 & .351 \\
\hline TM16 & .432 & .232 & .836 \\
\hline
\end{tabular}


Table 4.8 The mean of the three push factors

\begin{tabular}{|c|c|c|c|c|}
\hline & Push1 & Push2 & Push3 \\
\hline \multirow[t]{2}{*}{$\mathrm{N}$} & Valid & 159 & 159 & 159 \\
\hline & Missing & 0 & 0 & 0 \\
\hline \multicolumn{2}{|c|}{ Mean } & 3.2432 & 3.8302 & 3.0472 \\
\hline
\end{tabular}

\subsubsection{Tourism pull motivation}

The reliability of tourism pull motivation was good (Cronbach's Alpha $=0.720>0.7$ ) (Table 4.9). This shows that the internal consistency between the 7 items of tourism pull motivation is high. Meanwhile, the scale passes the KMO and Bartlett's Test $(\mathrm{KMO}=0.667>0.5$, Sig=0.000<0.05) (Table 4.10). Therefore, tourism pull motivation suitable to conduct factor analysis.

Table 4.9 The reliability of tourism pull motivation

\begin{tabular}{cc}
\hline Cronbach's Alpha & N of Items \\
.720 & 7 \\
\hline
\end{tabular}

Table 4.10 The KMO and Bartlett's test for tourism pull motivation Kaiser-Meyer-Olkin Measure of Sampling Adequacy.

df

Sig. .000

The total variance explanation table shows that the first three factors extracted can explain 71.197\% (Table 4.11). The scree plot shows that starting from the fourth factor, the subsequent factors have little difference in eigenvalues (Figure 4.2). Therefore, the first three factors are extracted. 
Table 4.11 The total variance explanation for tourism pull motivation

\begin{tabular}{|c|c|c|c|c|c|c|c|}
\hline \multirow[b]{2}{*}{ Component } & \multicolumn{3}{|c|}{ Initial Eigenvalues } & \multicolumn{3}{|c|}{$\begin{array}{c}\text { Extraction Sums of Squared } \\
\text { Loadings }\end{array}$} & \multirow{2}{*}{$\begin{array}{c}\text { Rotation } \\
\text { Sums of } \\
\text { Squared } \\
\text { Loadings }\end{array}$} \\
\hline & Total & $\begin{array}{c}\% \text { of } \\
\text { Variance }\end{array}$ & Cumulative \% & Total & $\begin{array}{c}\% \text { of } \\
\text { Variance }\end{array}$ & Cumulative \% & \\
\hline 1 & 2.681 & 38.294 & 38.294 & 2.681 & 38.294 & 38.294 & 2.169 \\
\hline 2 & 1.427 & 20.393 & 58.686 & 1.427 & 20.393 & 58.686 & 2.127 \\
\hline 3 & .876 & 12.511 & 71.197 & .876 & 12.511 & 71.197 & 1.204 \\
\hline 4 & .812 & 11.593 & 82.790 & & & & \\
\hline 5 & .477 & 6.811 & 89.602 & & & & \\
\hline 6 & .393 & 5.619 & 95.220 & & & & \\
\hline 7 & .335 & 4.780 & 100.000 & & & & \\
\hline
\end{tabular}

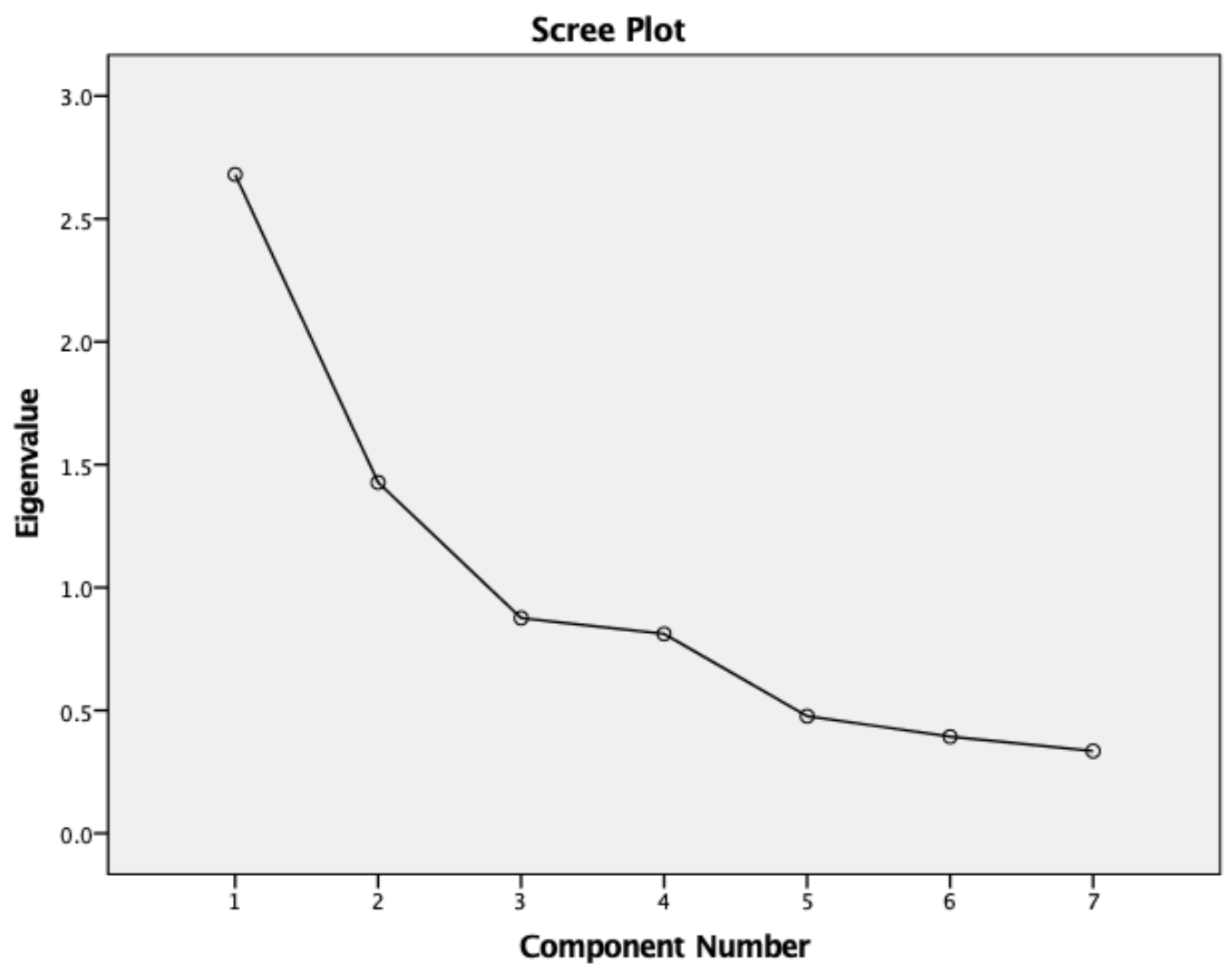

Figure 4.2 The scree plot for tourism pull motivation

The structure matrix (Table 4.12) indicates that the factor loadings of TM4, TM13, TM19 are higher on factor1, the factor loadings of TM3, TM17, TM18 are higher on factor2, while the 
factor loadings of TM15 are higher on factor3. Therefore, factor 1 is named as "self-reward", factor 2 is named as "advantages of the scenic spot", and factor 3 is named as "health need". Table 4.13 shows the mean of the three pull factors.

Table 4.12 The structure matrix for tourism pull motivation

\begin{tabular}{|l|l|r|r|}
\hline \multirow{2}{*}{} & \multicolumn{3}{|c|}{ Component } \\
\cline { 2 - 4 } & \multicolumn{1}{|l|}{1} & \multicolumn{1}{c|}{2} & \multicolumn{1}{l|}{3} \\
\hline TM3 & .497 & .700 & -.174 \\
\hline TM4 & .875 & .216 & .076 \\
\hline TM13 & .773 & .034 & .435 \\
\hline TM15 & .317 & .232 & .899 \\
\hline TM17 & .170 & .869 & .103 \\
\hline TM18 & .157 & .824 & .335 \\
\hline TM19 & .636 & .320 & .216 \\
\hline
\end{tabular}

Table 4.13 The mean of the three pull factors

\begin{tabular}{|c|c|c|c|c|}
\hline & Pull1 & Pull2 & Pull3 \\
\hline \multirow[t]{2}{*}{$N$} & Valid & 159 & 159 & 159 \\
\hline & Missing & 0 & 0 & 0 \\
\hline \multicolumn{2}{|c|}{ Mean } & 3.1405 & 4.1719 & 3.75 \\
\hline
\end{tabular}

\subsection{Factors influencing tourism motivation}

Reliability analysis and factor analysis was conducted for the factors influencing tourism motivation. First, the reliability was good (Cronbach's Alpha $=0.770>0.7)$ (Table 4.14). This shows that the internal consistency between the 6 items of the factors influencing tourism motivation is high. Second, in the factor analysis, the scale passes the KMO and Bartlett's Test $(\mathrm{KMO}=0.705>0.5, \mathrm{Sig}=0.000<0.05)$ (Table 4.15). Therefore, the factors influencing tourism motivation suitable to conduct factor analysis. Just one factor was extracted, which explained $48.792 \%$ of the total variance (Table 4.16 ).

Table 4.14 The reliability of the factors influencing tourism motivation

\begin{tabular}{cc}
\hline Cronbach's Alpha & N of Items \\
.770 & 6 \\
\hline
\end{tabular}


Table 4.15 The KMO and Bartlett's test for the factors influencing tourism motivation Kaiser-Meyer-Olkin Measure of Sampling Adequacy. .705 Bartlett's Test of Sphericity 288.694 273.792 15 .000 .000

Table 4.16 The total variance explanation for the factors influencing tourism motivation

\begin{tabular}{|l|r|r|r|r|r|r|}
\hline \multirow{2}{*}{ Component } & \multicolumn{3}{|c|}{ Initial Eigenvalues } & \multicolumn{3}{c|}{ Extraction Sums of Squared Loadings } \\
\cline { 2 - 7 } & \multicolumn{1}{|c|}{ Total } & \% of Variance & Cumulative \% & Total & \% of Variance & Cumulative \% \\
\hline 1 & 2.927 & 48.792 & 48.792 & 2.927 & 48.792 & 48.792 \\
\hline 2 & .946 & 15.766 & 64.557 & & & \\
\hline 3 & .862 & 14.367 & 78.924 & & & \\
\hline 4 & .570 & 9.505 & 88.429 & & & \\
\hline 5 & .426 & 7.099 & 95.528 & & & \\
\hline 6 & .268 & 4.472 & 100.000 & & & \\
\hline
\end{tabular}

\subsection{Factors influencing tourist satisfaction}

Reliability analysis and factor analysis was conducted for the tourist satisfaction affecting factors. The factors influencing tourist satisfaction was very reliable. (Cronbach's Alpha $=0.821>0.7$ ) (Table 4.17). This shows that the internal consistency between the 11 items of the factors influencing tourist satisfaction is high. Meanwhile, the scale passes the KMO and Bartlett's Test $(K M O=0.814>0.5$, Sig $=0.000<0.05)$ (Table 4.18). Therefore, the factors influencing tourist satisfaction suitable to conduct factor analysis.

Table 4.17 The reliability of the factors influencing tourist satisfaction

Cronbach's Alpha N of Items

.821

11

Table 4.18 The KMO and Bartlett's test for the factors influencing tourist satisfaction

\begin{tabular}{llr}
\hline Kaiser-Meyer-Olkin Measure of Sampling Adequacy. & .814 \\
Bartlett's Test of Sphericity & Approx. Chi- & 635.678 \\
& Square & 55 \\
df & .000 \\
\hline
\end{tabular}


The total variance explanation table shows that the first three factors extracted can explain 64.764\% (Table 4.19). The scree plot shows that starting from the fourth factor, the subsequent factors have little difference in eigenvalues (Figure 4.3). Therefore, the first three factors are extracted.

Table 4.19 The total variance explanation for the factors influencing tourist satisfaction

\begin{tabular}{|c|c|c|c|c|c|c|c|}
\hline \multirow[b]{2}{*}{ Component } & \multicolumn{3}{|c|}{ Initial Eigenvalues } & \multicolumn{3}{|c|}{$\begin{array}{l}\text { Extraction Sums of Squared } \\
\text { Loadings }\end{array}$} & \multirow{2}{*}{$\begin{array}{c}\text { Rotation } \\
\text { Sums of } \\
\text { Squared } \\
\text { Loadings }^{\text {a }} \\
\text { Total }\end{array}$} \\
\hline & Total & $\begin{array}{c}\% \text { of } \\
\text { Variance }\end{array}$ & Cumulative \% & Total & $\begin{array}{c}\% \text { of } \\
\text { Variance }\end{array}$ & Cumulative \% & \\
\hline 1 & 4.393 & 39.935 & 39.935 & 4.393 & 39.935 & 39.935 & 3.762 \\
\hline 2 & 1.392 & 12.655 & 52.591 & 1.392 & 12.655 & 52.591 & 2.845 \\
\hline 3 & 1.339 & 12.173 & 64.764 & 1.339 & 12.173 & 64.764 & 2.747 \\
\hline 4 & .744 & 6.764 & 71.528 & & & & \\
\hline 5 & .658 & 5.982 & 77.510 & & & & \\
\hline 6 & .602 & 5.469 & 82.978 & & & & \\
\hline 7 & .500 & 4.550 & 87.528 & & & & \\
\hline 8 & .409 & 3.715 & 91.244 & & & & \\
\hline 9 & .368 & 3.349 & 94.593 & & & & \\
\hline 10 & .328 & 2.982 & 97.574 & & & & \\
\hline 11 & .267 & 2.426 & 100.000 & & & & \\
\hline
\end{tabular}

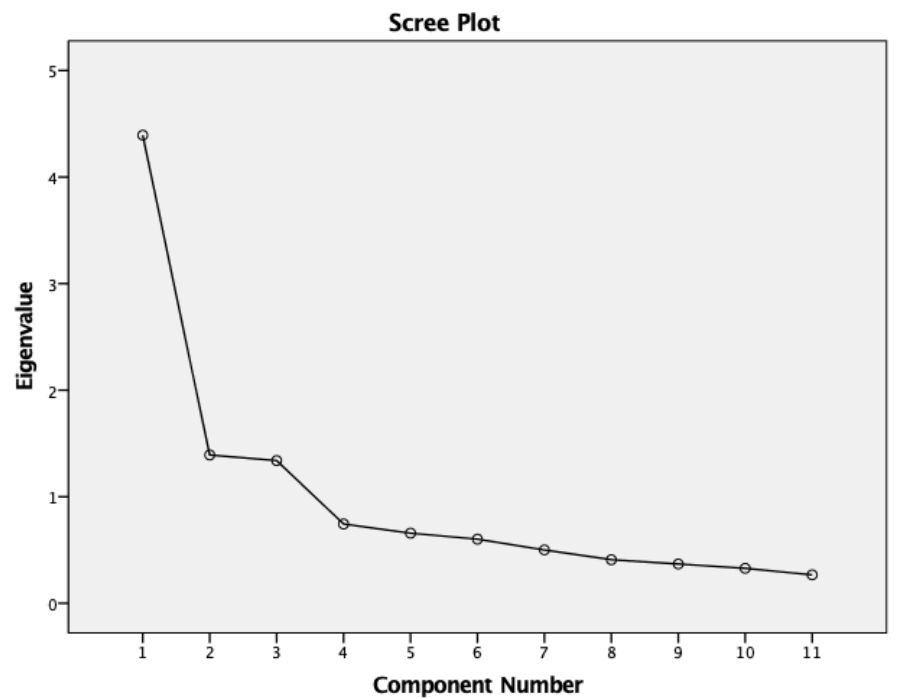

Figure 4.3 The scree plot for the factors influencing tourist satisfaction 
The structure matrix (Table 4.20) indicates that the factor loadings of IF(TS)2, IF(TS)9, IF(TS)10, IF(TS)11 are higher on factor1, the factor loadings of IF(TS)5, IF(TS)6, IF(TS)7, IF(TS) 8 are higher on factor2, while the factor loadings of IF(TS)1, IF(TS)3, IF(TS)4 are higher on factor3. Therefore, factor 1 is named as "tour related dimensions", factor 2 is named as "the environmental factor", and factor 3 is named as "experience and perception of tourist". Table 4.21 represents the mean of the three factors that affect tourist satisfaction.

Table 4.20 The structure matrix for the factors influencing tourist satisfaction

\begin{tabular}{|l|l|r|r|}
\hline \multirow{2}{*}{} & \multicolumn{3}{|c|}{ Component } \\
\cline { 2 - 4 } & 1 & \multicolumn{1}{|c|}{2} & \multicolumn{1}{l|}{3} \\
\hline IF(TS)1 & .279 & .204 & .892 \\
\hline IF(TS)2 & .752 & .295 & .375 \\
\hline IF(TS)3 & .677 & .302 & .699 \\
\hline IF(TS)4 & .295 & .312 & .804 \\
\hline IF(TS)6 & .621 & .709 & .409 \\
\hline IF(TS)7 & .596 & .755 & .292 \\
\hline IF(TS)8 & .058 & .794 & .112 \\
\hline IF(TS)9 & .425 & .749 & .339 \\
\hline IF(TS)10 & .692 & .387 & .082 \\
\hline IF(TS)11 & .808 & .265 & .220 \\
\hline
\end{tabular}

Table 4.21 The mean of the factors influencing tourist satisfaction

\begin{tabular}{|l|l|r|r|r|}
\hline \multicolumn{2}{|l|}{} & factor1 & factor2 & factor3 \\
\hline \multirow{2}{*}{$\mathrm{N}$} & Valid & 159 & 159 & 159 \\
\cline { 2 - 5 } & Missing & 0 & 0 & 0 \\
\hline \multicolumn{2}{|l|}{ Mean } & 4.3648 & 4.0896 & 3.6960 \\
\hline
\end{tabular}

\subsection{The influence of tourism motivation on tour quality}

A standard regression analysis was conducted in order to verify the research hypothesis, proposed in the previous chapter.

In order to conduct the regression analysis, 19 items of the tourism motivation were computed to one variable named as tourism motivation by SPSS. Table 4.22 shows tourism 
motivation has a significantly positive regression weight on tour quality $(b=0.294$, sig $=$ $0.000<0.05)$, which indicates that as the tourism motivation becomes higher, the tour quality increases. Therefore, Hypothesis 1 is proved.

Table 4.22 The influence of tourism motivation on tour quality

\begin{tabular}{|c|c|c|c|c|c|c|}
\hline \multirow{3}{*}{$\begin{array}{l}\text { Dependent } \\
\text { Variable }\end{array}$} & \multirow{3}{*}{$\begin{array}{l}\text { Independent } \\
\text { Variable }\end{array}$} & \multicolumn{5}{|c|}{ Standardized } \\
\hline & & \multicolumn{5}{|c|}{ Unstandardized Coefficients Coefficients } \\
\hline & & $\mathrm{B}$ & Std. Error & Beta & $\mathrm{t}$ & Sig. \\
\hline \multirow[t]{3}{*}{ Tour Quality } & (Constant) & 2.443 & .342 & & 7.149 & .000 \\
\hline & Tourism & & & & & \\
\hline & Motivation & .369 & .096 & .294 & 3.857 & .000 \\
\hline
\end{tabular}

\subsection{The influence of tourism expectation on tourism quality}

As shown in Table 4.23, the tourism expectation has a significantly positive regression weight on tour quality $(b=0.384$, sig $=0.000<0.05)$, which indicates that as the tourism expectation becomes higher, the tour quality increases. Therefore, the result does not support hypothesis 2 .

Table 4.23 The influence of tourism expectation on tour quality

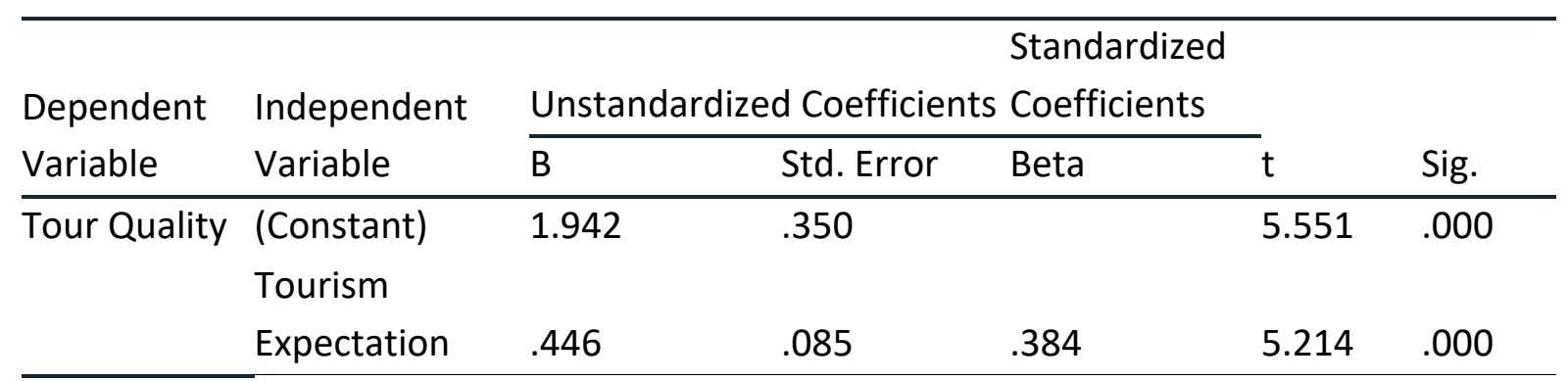

\subsection{The influence of tour quality on tourist satisfaction}

Table 4.24 shows tour quality has a significantly positive effect on tourist satisfaction $(b=$ 0.613 , sig $=0.000<0.05)$, which indicates that as the tour quality becomes higher, the tourist satisfaction increases. Therefore, Hypothesis 3 is proved. 
Table 4.24 The influence of tour quality on tourist satisfaction

\begin{tabular}{|c|c|c|c|c|c|c|}
\hline \multirow{3}{*}{$\begin{array}{l}\text { Dependent } \\
\text { Variable }\end{array}$} & \multirow{3}{*}{$\begin{array}{l}\text { Independent } \\
\text { Variable }\end{array}$} & \multicolumn{5}{|c|}{ Standardized } \\
\hline & & \multicolumn{5}{|c|}{ Unstandardized Coefficients Coefficients } \\
\hline & & B & Std. Error & Beta & $\mathrm{t}$ & Sig. \\
\hline Tourist & (Constant) & 1.584 & .235 & & 6.735 & .000 \\
\hline satisfaction & Tour Quality & .596 & .061 & .613 & 9.722 & .000 \\
\hline
\end{tabular}

\subsection{The influence of the demographic characteristics}

The demographic characteristics of the participants were added to the regression model as six control variables and the results as shown in Table 4.25 show that all six control variables, including health status, marital status, education, age, gender, and annual income, have no significant effect on satisfaction. In addition, in model 1 , the original $R$ Square is 0.471 , and R Square in model 2 is 0.482 (Table 4.26). The little variance of R Square indicated the control variables explained the scarce variance of satisfaction.

Table 4.25 The influence of the demographic characteristics

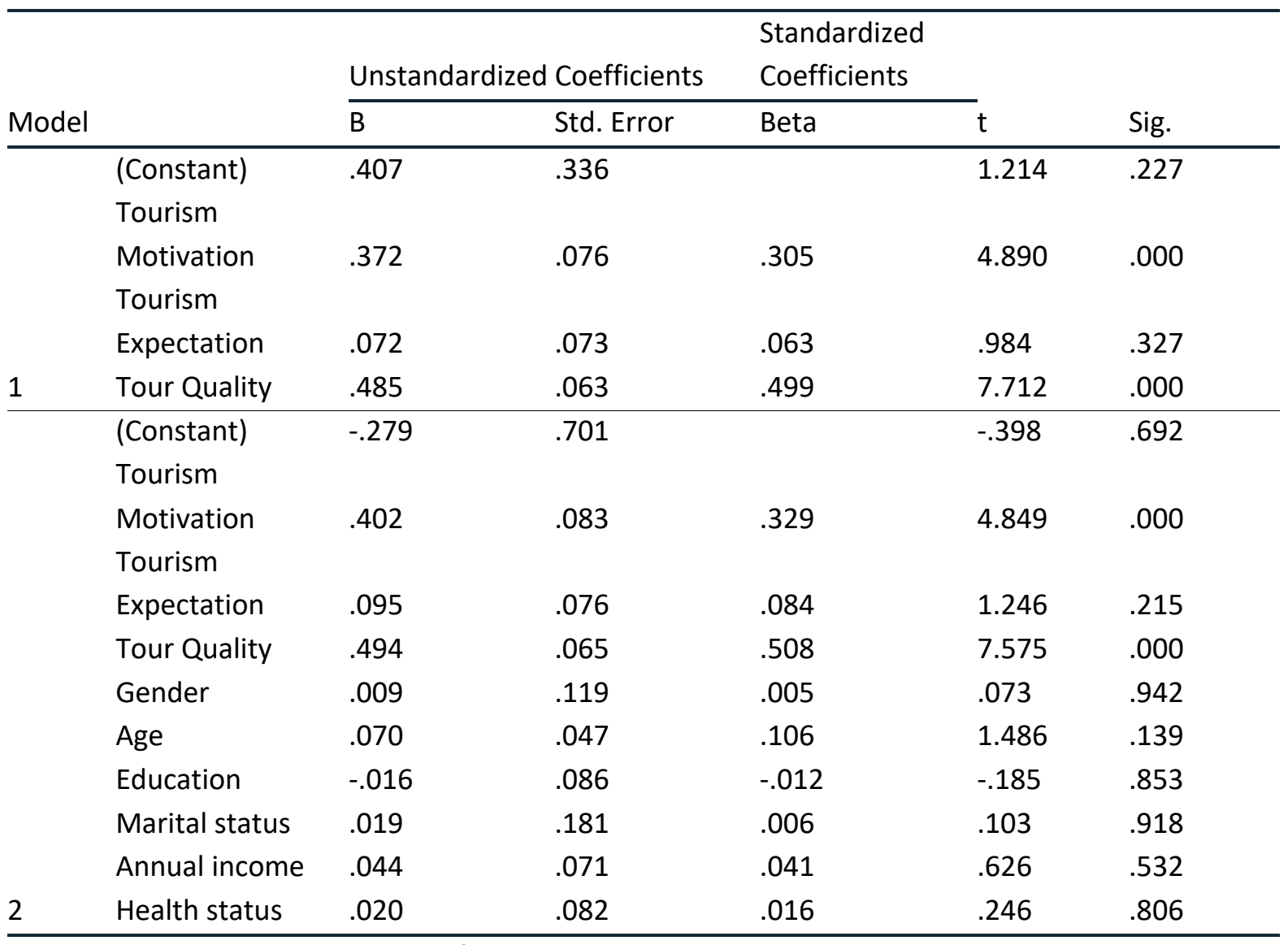

a. Dependent Variable: Tourist satisfaction 
Table 4.26 The control variables model

\begin{tabular}{|c|c|c|c|c|}
\hline Model & $\mathrm{R}$ & R Square & $\begin{array}{l}\text { Adjusted R } \\
\text { Square }\end{array}$ & $\begin{array}{l}\text { Std. Error of } \\
\text { the Estimate }\end{array}$ \\
\hline 1 & $.686 a$ & .471 & .461 & .625 \\
\hline 2 & $.694 b$ & .482 & .451 & .631 \\
\hline
\end{tabular}

\subsection{Mediation analysis of tour quality}

The mediating effect of perception was tested step by step according to casual step regression (Baron \& Kenny, 1986). As the Model 2 in Table 4.27 shew, tourism motivation influences tourist satisfaction very positively $(b=.405$, sig $=.000<0.05)$. In Model 1 , tourism motivation has a significantly positive effect on tour quality $(b=.200$, sig $=.009<0.05)$. In Model 3, tourism motivation still has a significantly positive effect on tourist satisfaction $(b=.305$, sig $=.000<0.05)$, indicating there is a partial mediation between tourist satisfaction and tourism motivation.

In the same way, as in Model 2 displayed, tourism expectation does have a significantly positive impact on tourist satisfaction $(b=.226$, sig $=.002<0.05)$. In Model 1 , tourism expectation has a significantly positive impact on tour quality $(b=.327$, sig $=.000<0.05)$. In Model 3, tourism expectation doesn't have a big impact on tourist satisfaction $(b=.984$, sig $=.327$ ), indicating that a complete mediation is between tourist satisfaction and tourism expectation.

In short, results demonstrate the relationship between tourist satisfaction and tourism motivation can be partially mediated by tour quality, which is able to mediate the relationship between tourist satisfaction and tourism expectation completely. According to the results, the mediation effect model of tourism quality is made (Figure 4.4). 
Table 4.27 Coefficients of regression models

\begin{tabular}{|c|c|c|c|c|c|c|c|}
\hline \multirow[b]{3}{*}{ Model } & \multirow{3}{*}{$\begin{array}{l}\text { Dependent } \\
\text { Variable }\end{array}$} & \multirow{3}{*}{$\begin{array}{l}\text { Independent } \\
\text { Variable }\end{array}$} & \multirow{2}{*}{\multicolumn{2}{|c|}{$\begin{array}{l}\text { Unstandardized } \\
\text { Coefficients }\end{array}$}} & \multirow{2}{*}{\multicolumn{2}{|c|}{$\begin{array}{l}\text { Standardized } \\
\text { Coefficients }\end{array}$}} & \multirow[b]{3}{*}{ Sig. } \\
\hline & & & & & & & \\
\hline & & & $\mathrm{B}$ & Std. Error & Beta & $\mathrm{t}$ & \\
\hline & & (Constant) & 1.331 & .414 & & 3.218 & .002 \\
\hline & & Tourism & & & & & \\
\hline & & Motivation & .251 & .095 & .200 & 2.654 & .009 \\
\hline & & Tourism & & & & & \\
\hline \multirow[t]{5}{*}{1} & Tour Quality & Expectation & .379 & .088 & .327 & 4.327 & .000 \\
\hline & & (Constant) & 1.053 & .381 & & 2.764 & .006 \\
\hline & & Tourism & & & & & \\
\hline & & Motivation & .494 & .087 & .405 & 5.661 & .000 \\
\hline & Tourist & Tourism & & & & & \\
\hline \multirow[t]{6}{*}{2} & satisfaction & Expectation & .255 & .081 & .226 & 3.166 & .002 \\
\hline & & (Constant) & .407 & .336 & & 1.214 & .227 \\
\hline & & Tourism & & & & & \\
\hline & & Motivation & .372 & .076 & .305 & 4.890 & .000 \\
\hline & & Tourism & & & & & \\
\hline & Tourist & Expectation & .072 & .073 & .063 & .984 & .327 \\
\hline \multirow[t]{2}{*}{3} & satisfaction & Tour Quality & .485 & .063 & .499 & 7.712 & .000 \\
\hline & Tourist & (Constant) & 1.584 & .235 & & 6.735 & .000 \\
\hline \multirow[t]{3}{*}{4} & satisfaction & Tour Quality & .596 & .061 & .613 & 9.722 & .000 \\
\hline & & (Constant) & 1.317 & .088 & & 15.009 & .000 \\
\hline & Future & Tourist & & & & & \\
\hline 5 & Behavior & satisfaction & -.051 & .022 & -.178 & -2.266 & .025 \\
\hline
\end{tabular}

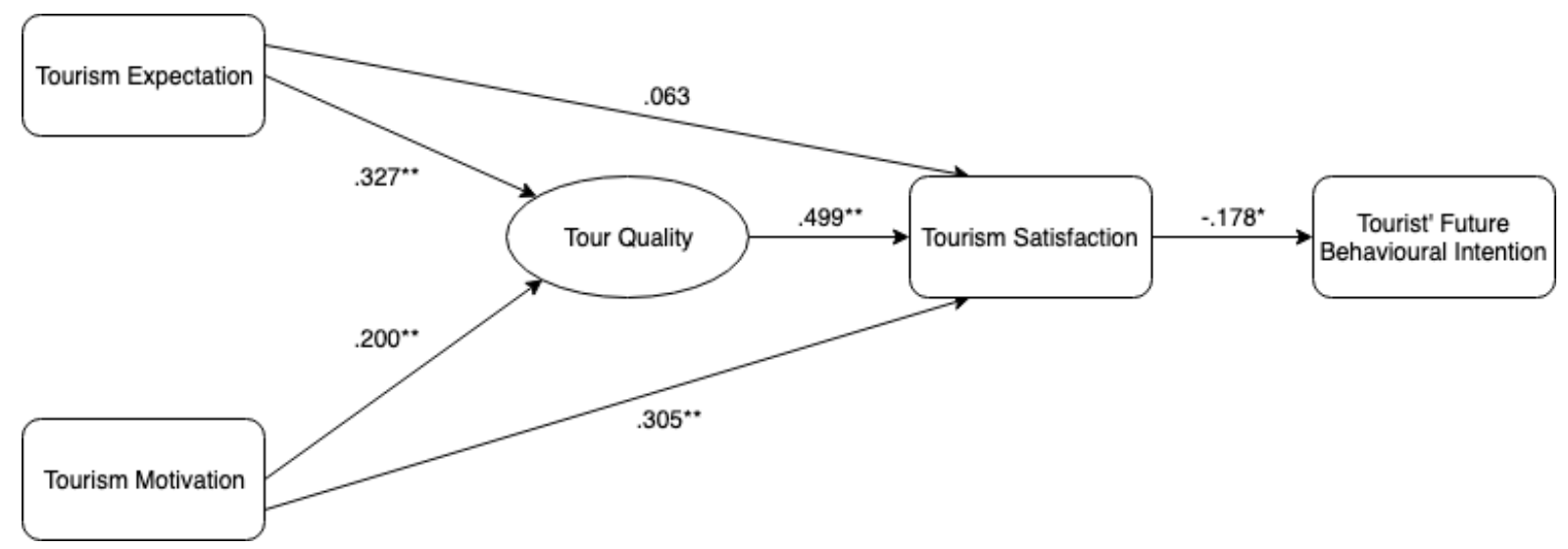

Figure 4.4 The mediating effect of tour quality. ${ }^{*} p<0.05,{ }^{* *} p<0.01$. 


\subsection{The influence of tourist satisfaction on tourists' future behavioural intention}

In order to conduct the regression analysis, 2 items of the tourists' future behavioural intention were computed to one variable named as future behaviour by SPSS. Table 4.28 shows the standard regression analysis results, which shows that tourist satisfaction has a significantly negative regression weight on tourists' future behavioural intention $(b=-0.178$, sig $=0.000<0.05)$, indicating as tourist satisfaction becomes higher, the tourists' future behavioural intention decreases. Therefore, Hypothesis 4 is proved.

Table 4.28 The influence of tourist satisfaction on tourists' future behavioural intention

\begin{tabular}{|c|c|c|c|c|c|c|}
\hline \multirow{3}{*}{$\begin{array}{l}\text { Dependent } \\
\text { Variable }\end{array}$} & \multirow{3}{*}{$\begin{array}{l}\text { Independent } \\
\text { Variable }\end{array}$} & \multicolumn{5}{|c|}{ Standardized } \\
\hline & & \multicolumn{3}{|c|}{ Unstandardized Coefficients Coefficients } & \multirow[b]{2}{*}{$\mathrm{t}$} & \multirow[b]{2}{*}{ Sig. } \\
\hline & & $\mathrm{B}$ & Std. Error & Beta & & \\
\hline Future & (Constant) & 1.317 & .088 & & 15.009 & .000 \\
\hline \multirow[t]{2}{*}{ behaviour } & Tourist & & & & & \\
\hline & satisfaction & -.051 & .022 & -.178 & -2.266 & .025 \\
\hline
\end{tabular}




\section{Chapter 5 Discussion}

\subsection{Introduction}

The previous chapter presents data analysis results and validated the previously proposed hypotheses. This chapter will analyse all the research results and determine the motivation and satisfaction model of Chinese senior tourists on day trips.

\subsection{Tourism motivation}

The researchers presented 19 tourism motivations in the questionnaire and asked participants to propose new motivations if they had. The results showed that only one of the 159 people proposed two new motives, shopping and introduce local attractions to friends from other provinces, which were not universal. Therefore, the researcher determines that the tourism motivation of Chinese senior tourists for day trips are 19 items (Table 5.1). It is divided into 12 push motivations and 7 pull motivations.

The mean value of the tourism motivation score indicates that for Chinese senior day trips tourists, the three most important push motivations are: "there are some places I have always wanted to visit" (4.19), "I want to see the things that I don't normally see" (4.08), and "share travel experiences with friends and relatives" (3.68). The top three important pull motivations are "outstanding scenery" (4.37), "historical sights" (4.23), and "the availability of a good restaurant and delicious food" (3.91) (Table 5.1).

In this research, the tourism motivation of Chinese senior tourists on day trips is similar to the findings of other research (Zhang \& Lam, 1999, Horneman et al., 2002, Jang, \& Wu, 2006). All the findings put "knowledge-seeking" as a critical tourism motivation. This means, though the Chinese senior tourists have old age, they still have the enthusiasm for pursuing knowledge. However, the result is inconsistent with the conclusions of Huang and Tsai (2003), who find the most driven tourism motivation for seniors in Taiwan is "rest and relaxation". The study results show that delicious food is also a critical tourist motivation for Chinese elderly tourists. This also validates the findings of Balderas-Cejudo et al. (2019) and 
the findings of Horn and Tsai (2010). Delicious food has become a major reason for the elderly to participate in tourism activities.

Table 5.1 Tourism motivation items and mean value

\begin{tabular}{|c|c|c|}
\hline & Items & Mean \\
\hline \multirow{12}{*}{$\begin{array}{c}\text { Tourism } \\
\text { motivation } \\
\text { (Push) }\end{array}$} & There are some places I have always wanted to visit. & 4.19 \\
\hline & I want to see the things that I don't normally see. & 4.08 \\
\hline & Share travel experiences with friends and relatives. & 3.68 \\
\hline & Get a new experience. & 3.52 \\
\hline & Satisfy curiosity. & 3.52 \\
\hline & I want to get a rest and relax. & 3.43 \\
\hline & Attend the cultural events. & 3.42 \\
\hline & Meet friends and socialization. & 3.16 \\
\hline & I just want to slow down. & 3.09 \\
\hline & Nostalgic. & 3.07 \\
\hline & Visit relatives. & 3.03 \\
\hline & Special events and attractions (such as visit the Buddha, praying, etc.). & 2.68 \\
\hline \multirow{7}{*}{$\begin{array}{c}\text { Tourism } \\
\text { motivation } \\
\text { (Pull) }\end{array}$} & Outstanding scenery. & 4.37 \\
\hline & Historical sights. & 4.23 \\
\hline & The availability of a good restaurant and delicious food. & 3.91 \\
\hline & Fitness and physical exercise. & 3.75 \\
\hline & Friends' recommendations. & 3.55 \\
\hline & Have someplace can buy things on the trip. & 2.97 \\
\hline & A reward for your previous hard work. & 2.91 \\
\hline
\end{tabular}

For different characteristics of senior people, the importance of tourism motivation is also different. Table 5.2 shows the impact of gender differences on the significance of tourism motivation. For male seniors, the most important push motivation is "There are some places I have always wanted to visit" (4.22), followed by "I want to see the things that I don't normally see" (4.12), and "Share travel experiences with friends and relatives" (3.78). The most important pull motivation is "Outstanding scenery" (4.35), followed by "Historical sights" (4.24). However, the most important push motivation for female seniors is "There are some places I have always wanted to visit" (4.15), followed by "I want to see the things 
that I don't normally see" (4.00), and "Satisfy curiosity." (3.46). The most important pull motivation for female seniors is "The availability of a good restaurant and delicious food" (4.02), followed by "Have someplace can buy things on the trip." (3.06).

The results show that regardless of gender, the most important motivation for Chinese senior tourist on day trips is to go where they have always wanted to visit and to see things what they usually cannot see. However, sharing travel experiences with family members and friends is also important to male seniors in tourism activities. For older women, it is more important to participate in tourism activity to satisfy curiosity. In addition, beautiful scenery and historical attractions can drive older men to travel, while older women are attracted to delicious food and shopping. This result also validates the findings in the previous literature (Moscardo, 2004, Bowen \& Clarke, 2009, Horng \& Tsai, 2010, Lehto et al., 2014, Balderas-Cejudo et al., 2019). Food has become a new field of tourism. Many older people will participate in tourism activities in pursuit of delicious food. Similarly, like food, shopping is an important part of tourism activities. Chinese senior tourists also consider shopping as an important motivation for travel. 
Table 5.2 Means of tourism motivation for different genders

\begin{tabular}{|c|c|c|c|}
\hline \multicolumn{2}{|r|}{ Tourism motivation } & Male & Female \\
\hline \multirow{12}{*}{$\begin{array}{c}\text { Tourism } \\
\text { motivation } \\
\text { (Push) }\end{array}$} & Share travel experiences with friends and relatives. & 3.78 & 3.44 \\
\hline & Attend the cultural events. & 3.86 & 4.02 \\
\hline & Get a new experience. & 4.12 & 4.00 \\
\hline & I want to see the things that I don't normally see. & 4.22 & 4.15 \\
\hline & There are some places I have always wanted to visit. & 3.50 & 3.23 \\
\hline & I want to get a rest and relax. & 3.53 & 3.19 \\
\hline & I just want to slow down. & 3.20 & 2.85 \\
\hline & Meet friends and socialization. & 3.28 & 2.90 \\
\hline & Visit relatives. & 3.23 & 2.56 \\
\hline & Satisfy curiosity. & 3.55 & 3.46 \\
\hline & Nostalgic. & 3.21 & 2.75 \\
\hline & $\begin{array}{l}\text { Special events and attractions (such as visit the } \\
\text { Buddha, praying, etc.). }\end{array}$ & 2.73 & 2.56 \\
\hline \multirow{7}{*}{$\begin{array}{c}\text { Tourism } \\
\text { motivation } \\
\text { (Pull) }\end{array}$} & $\begin{array}{l}\text { The availability of a good restaurant and delicious } \\
\text { food. }\end{array}$ & 2.93 & 3.06 \\
\hline & Have someplace can buy things on the trip. & 3.58 & 3.40 \\
\hline & A reward for your previous hard work. & 3.07 & 2.52 \\
\hline & Fitness and physical exercise. & 3.82 & 3.60 \\
\hline & Outstanding scenery. & 4.35 & 4.42 \\
\hline & Historical sights. & 4.24 & 4.21 \\
\hline & Friends' recommendations. & 3.64 & 3.33 \\
\hline
\end{tabular}

For people over the age of 56 , the importance of travel motivation remains consistent ((Table 5.3). The most important push motivations are "There are some places I have always wanted to visit" and "I want to see the things that I don't normally see." The most important pull motivations are "Outstanding scenery" and "Historical sights". Unlike people over the age of 56 , sharing a travel experience with family and friends and delicious food are very important for people aged 50-55. Fitness is also an important reason for travel for people aged 50-55 (mean > 4.0), but not important for people over 55 years old. This may be because the physical strength of the elderly will decline year by year, and the demand for fitness will become smaller, so as the age increases, the travel activity is more likely to visit the scenery instead of fitness. 
Table 5.3 Means of tourism motivation for different ages

\begin{tabular}{|c|c|c|c|c|c|c|}
\hline & Tourism motivation & $\begin{array}{l}50-55 \\
\text { years } \\
\text { old }\end{array}$ & $\begin{array}{l}56-60 \\
\text { years } \\
\text { old }\end{array}$ & $\begin{array}{l}61-65 \\
\text { years } \\
\text { old }\end{array}$ & $\begin{array}{l}66-70 \\
\text { years } \\
\text { old }\end{array}$ & $\begin{array}{l}\text { Over } \\
70 \\
\text { years } \\
\text { old }\end{array}$ \\
\hline \multirow{12}{*}{$\begin{array}{l}\text { Tourism } \\
\text { motivation } \\
\text { (Push) }\end{array}$} & $\begin{array}{l}\text { Share travel experiences with } \\
\text { friends and relatives. }\end{array}$ & 4.42 & 3.89 & 3.91 & 3.47 & 3.47 \\
\hline & Attend the cultural events. & 4.33 & 3.74 & 3.44 & 3.18 & 3.26 \\
\hline & Get a new experience. & 4.17 & 4.11 & 3.59 & 3.39 & 3.24 \\
\hline & $\begin{array}{l}\text { I want to see the things that I } \\
\text { don't normally see. }\end{array}$ & 4.17 & 4.47 & 3.97 & 4.03 & 4.03 \\
\hline & $\begin{array}{l}\text { There are some places I have } \\
\text { always wanted to visit. }\end{array}$ & 4.58 & 4.11 & 4.31 & 4.34 & 3.98 \\
\hline & I want to get a rest and relax. & 4.00 & 3.84 & 3.69 & 3.32 & 3.10 \\
\hline & I just want to slow down. & 4.08 & 3.84 & 3.63 & 2.89 & 2.48 \\
\hline & Meet friends and socialization. & 4.25 & 3.63 & 3.38 & 2.84 & 2.88 \\
\hline & Visit relatives. & 3.58 & 3.42 & 3.47 & 2.71 & 2.74 \\
\hline & Satisfy curiosity. & 3.92 & 3.63 & 3.78 & 3.58 & 3.22 \\
\hline & Nostalgic. & 3.58 & 3.63 & 3.25 & 3.05 & 2.69 \\
\hline & $\begin{array}{l}\text { Special events and attractions } \\
\text { (such as visit the Buddha, praying, } \\
\text { etc.). }\end{array}$ & 2.75 & 3.37 & 2.91 & 2.42 & 2.48 \\
\hline \multirow{7}{*}{$\begin{array}{l}\text { Tourism } \\
\text { motivation } \\
\text { (Pull) }\end{array}$} & $\begin{array}{l}\text { The availability of a good } \\
\text { restaurant and delicious food. }\end{array}$ & 4.58 & 4.16 & 4.00 & 3.97 & 3.60 \\
\hline & $\begin{array}{l}\text { Have someplace can buy things on } \\
\text { the trip. }\end{array}$ & 3.67 & 3.84 & 3.31 & 2.71 & 2.52 \\
\hline & $\begin{array}{l}\text { A reward for your previous hard } \\
\text { work. }\end{array}$ & 4.00 & 3.11 & 3.44 & 2.61 & 2.52 \\
\hline & Fitness and physical exercise. & 4.08 & 3.79 & 3.75 & 3.68 & 3.72 \\
\hline & Outstanding scenery. & 4.42 & 4.37 & 4.38 & 4.42 & 4.33 \\
\hline & Historical sights. & 4.08 & 4.26 & 4.31 & 4.29 & 4.17 \\
\hline & Friends' recommendations. & 3.67 & 3.89 & 3.81 & 3.32 & 3.41 \\
\hline
\end{tabular}

There are also differences in the importance of travel motivation for older people with different degrees of education (Table 5.4). For the elderly below the master's degree, places that have not been visited and beautiful scenery are important attractions. However, for older people with a doctoral degree or above, sharing travel experiences with family and friends, participating in cultural activities, rest, and getting a new experience are important factors in attracting them to travel. This shows that older people with more knowledge will pay more attention to the needs of intangible culture. 
Table 5.4 Means of tourism motivation for different education level

\begin{tabular}{|c|c|c|c|c|c|}
\hline & Tourism motivation & $\begin{array}{l}\text { Less than } \\
\text { undergrad } \\
\text { uate }\end{array}$ & $\begin{array}{l}\text { Undergr } \\
\text { aduate }\end{array}$ & $\begin{array}{l}\text { Master } \\
\text { degree }\end{array}$ & $\begin{array}{l}\text { Doctorate } \\
\text {, phd., dsc }\end{array}$ \\
\hline \multirow{12}{*}{$\begin{array}{c}\text { Tourism } \\
\text { motivation } \\
\text { (Push) }\end{array}$} & $\begin{array}{l}\text { Share travel experiences with } \\
\text { friends and relatives. }\end{array}$ & 3.81 & 3.52 & 4.11 & 4.50 \\
\hline & Attend the cultural events. & 3.59 & 3.24 & 3.67 & 4.50 \\
\hline & Get a new experience. & 3.46 & 3.53 & 3.78 & 4.00 \\
\hline & $\begin{array}{l}\text { I want to see the things that I } \\
\text { don't normally see. }\end{array}$ & 3.95 & 4.18 & 4.11 & 4.00 \\
\hline & $\begin{array}{l}\text { There are some places I have } \\
\text { always wanted to visit. }\end{array}$ & 4.13 & 4.25 & 4.22 & 4.00 \\
\hline & I want to get a rest and relax. & 3.56 & 3.29 & 3.56 & 4.50 \\
\hline & I just want to slow down. & 3.32 & 2.95 & 2.89 & 3.00 \\
\hline & Meet friends and socialization. & 3.41 & 2.98 & 3.22 & 3.00 \\
\hline & Visit relatives. & 3.19 & 2.92 & 2.78 & 3.50 \\
\hline & Satisfy curiosity. & 3.49 & 3.55 & 3.44 & 3.50 \\
\hline & Nostalgic. & 3.27 & 2.91 & 3.11 & 3.50 \\
\hline & $\begin{array}{l}\text { Special events and attractions } \\
\text { (such as visit the Buddha, praying, } \\
\text { etc.). }\end{array}$ & 2.63 & 2.67 & 2.89 & 3.50 \\
\hline \multirow{7}{*}{$\begin{array}{c}\text { Tourism } \\
\text { motivation } \\
\text { (Pull) }\end{array}$} & $\begin{array}{l}\text { The availability of a good } \\
\text { restaurant and delicious food. }\end{array}$ & 3.95 & 3.91 & 3.89 & 3.00 \\
\hline & $\begin{array}{l}\text { Have someplace can buy things } \\
\text { on the trip. }\end{array}$ & 3.10 & 2.87 & 3.00 & 3.00 \\
\hline & $\begin{array}{l}\text { A reward for your previous hard } \\
\text { work. }\end{array}$ & 2.95 & 2.86 & 2.89 & 3.50 \\
\hline & Fitness and physical exercise. & 3.62 & 3.84 & 4.00 & 3.50 \\
\hline & Outstanding scenery. & 4.30 & 4.42 & 4.44 & 4.00 \\
\hline & Historical sights. & 4.14 & 4.29 & 4.33 & 4.00 \\
\hline & Friends' recommendations. & 3.57 & 3.56 & 3.22 & 3.50 \\
\hline
\end{tabular}

The difference in personal annual income also affect the travel motivation of the elderly (Table 5.5). The factors that tend to attract older people with an annual income of less than 200,000 CNY to participate in tourism activities are places that have not been visited, things that are not normally seen, beautiful scenery or historical sights. However, older people with an annual income of more than 200,000 CNY will be attracted to delicious food, special events or attractions, and they will attach more importance to communicate with family and friends the experience of their journey. 
Table 5.5 Means of tourism motivation for different annual income

\begin{tabular}{|c|c|c|c|c|c|}
\hline \multicolumn{2}{|r|}{ Tourism motivation } & $\begin{array}{l}\text { Less } \\
\text { than } \\
50,000 \\
\text { CNY }\end{array}$ & $\begin{array}{l}50,001- \\
100,000 \\
\text { CNY }\end{array}$ & $\begin{array}{l}1000,001- \\
200,000 \\
\text { CNY }\end{array}$ & $\begin{array}{l}200,001- \\
300,000 \\
\text { CNY }\end{array}$ \\
\hline \multirow{12}{*}{$\begin{array}{l}\text { Tourism } \\
\text { motivation } \\
\text { (Push) }\end{array}$} & $\begin{array}{l}\text { Share travel experiences } \\
\text { with friends and relatives. }\end{array}$ & 5.00 & 3.73 & 2.78 & 3.00 \\
\hline & Attend the cultural events. & 3.00 & 3.45 & 3.00 & 3.00 \\
\hline & Get a new experience. & 4.00 & 3.54 & 3.22 & 3.00 \\
\hline & $\begin{array}{l}\text { I want to see the things that } \\
\text { I don't normally see. }\end{array}$ & 5.00 & 4.06 & 4.33 & 4.00 \\
\hline & $\begin{array}{l}\text { There are some places I have } \\
\text { always wanted to visit. }\end{array}$ & 5.00 & 4.19 & 4.22 & 4.00 \\
\hline & $\begin{array}{l}\text { I want to get a rest and } \\
\text { relax. }\end{array}$ & 1.00 & 3.49 & 2.89 & 2.00 \\
\hline & I just want to slow down. & 1.00 & 3.20 & 1.89 & 1.00 \\
\hline & $\begin{array}{l}\text { Meet friends and } \\
\text { socialization. }\end{array}$ & 3.00 & 3.25 & 1.89 & 2.00 \\
\hline & Visit relatives. & 2.00 & 3.07 & 2.33 & 3.00 \\
\hline & Satisfy curiosity. & 4.00 & 3.58 & 2.56 & 3.00 \\
\hline & Nostalgic. & 1.00 & 3.16 & 1.89 & 2.00 \\
\hline & $\begin{array}{l}\text { Special events and } \\
\text { attractions (such as visit the } \\
\text { Buddha, praying, etc.). }\end{array}$ & 1.00 & 2.74 & 1.78 & 3.00 \\
\hline \multirow{7}{*}{$\begin{array}{l}\text { Tourism } \\
\text { motivation } \\
\text { (Pull) }\end{array}$} & $\begin{array}{l}\text { The availability of a good } \\
\text { restaurant and delicious } \\
\text { food. }\end{array}$ & 5.00 & 3.93 & 3.56 & 3.00 \\
\hline & $\begin{array}{l}\text { Have someplace can buy } \\
\text { things on the trip. }\end{array}$ & 3.00 & 3.01 & 2.33 & 2.00 \\
\hline & $\begin{array}{l}\text { A reward for your previous } \\
\text { hard work. }\end{array}$ & 2.00 & 2.96 & 2.33 & 1.00 \\
\hline & $\begin{array}{l}\text { Fitness and physical } \\
\text { exercise. }\end{array}$ & 4.00 & 3.75 & 3.78 & 4.00 \\
\hline & Outstanding scenery. & 5.00 & 4.34 & 4.78 & 4.00 \\
\hline & Historical sights. & 5.00 & 4.21 & 4.67 & 3.00 \\
\hline & Friends' recommendations. & 4.00 & 3.59 & 2.78 & 3.00 \\
\hline
\end{tabular}

The 12 push tourism motivations are divided into three categories by factor analysis, which are "relaxation and sociality", "knowledge-seeking", and "intangible cultural need".

"Relaxation and sociality" category include "share travel experiences with friends and relatives", "I want to get a rest and relax", "I just want to slow down", "meet friends and socialization", "visit relatives", and "nostalgic". "Knowledge-seeking" category includes "get a new experience", "I want to see the things that I don't normally see", "there are some 
places I have always wanted to visit", "satisfy curiosity". "Intangible cultural need" category includes "attend the cultural events", and "I want to see the things that I don't normally see". For Chinese senior day trips tourists, the most important push motivation category is "knowledge-seeking" (mean=3.83) (Table 5.6).

Table 5.6 The mean of the tourism motivation categories

\begin{tabular}{|c|c|c|c|c|c|c|}
\hline & \multicolumn{3}{|c|}{ Push motivation } & \multicolumn{3}{c|}{ Pull motivation } \\
\hline Categories & $\begin{array}{c}\text { Relaxation } \\
\text { and } \\
\text { sociality }\end{array}$ & $\begin{array}{c}\text { Knowledge- } \\
\text { seeking }\end{array}$ & $\begin{array}{c}\text { Intangible } \\
\text { cultural } \\
\text { need }\end{array}$ & Self-reward & $\begin{array}{c}\text { Advantages } \\
\text { of the } \\
\text { scenic spot }\end{array}$ & $\begin{array}{c}\text { Health } \\
\text { need }\end{array}$ \\
\hline Mean & 3.2432 & 3.8302 & 3.0472 & 3.1405 & 4.1719 & 3.75 \\
\hline
\end{tabular}

The 7 pull tourism motivations are divided into three categories by factor analysis, which are "self-reward", "advantages of the scenic spot", and "health need". "Self-reward" category includes "have someplace can buy things on the trip", "a reward for your previous hard work", and "friends' recommendations". "Advantages of the scenic spot" category includes "the availability of a good restaurant and delicious food", "outstanding scenery", and "historical sights". "Health need" category includes "fitness and physical exercise". For Chinese senior day trips tourists, the most important pull motivation category is "advantages of the scenic spot" (mean=4.17) (Table 5.6).

This result is the same as the findings of Huang and Tsai (2003). Because Huang and Tsai (2003) found that a great number of senior people in Taiwan are attracted with historical sights and beautiful scenery, and in this research, "historical sights" and "outstanding scenery" are also the most important pull motivations for Chinese senior tourists on day trips. However, this is not similar to the results of Jang and Wu (2006), who found that the most important pull motivation for senior in Taiwan is "cleanliness \& safety".

Therefore, the model of tourist motivation of Chinese senior tourist on day trips is determined (Figure 5.1). 


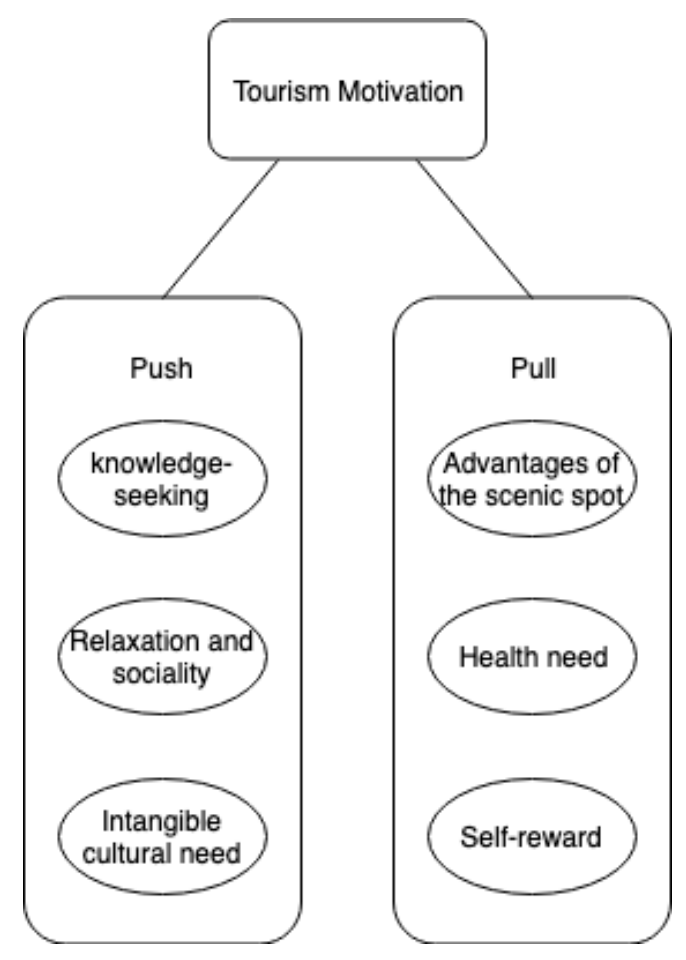

Figure 5.1 Tourism motivation model

\subsection{Factors influencing tourism motivation}

The researcher presented 6 factors influencing tourism motivation in the questionnaire and asked participants to propose new factors if they had. The results showed that no one proposed new factors. Therefore, the researcher determines that the influencing factor of tourism motivation of Chinese senior tourists for day trips are 6 items (Table 5.7).

Table 5.7 The mean value of factors influencing tourism motivation

\begin{tabular}{|l|c|}
\hline \multicolumn{1}{|c|}{ Factors } & Mean \\
\hline Health status & 4.28 \\
\hline Traffic condition & 4.12 \\
\hline Season and weather conditions & 4.06 \\
\hline Overall cost of travel (including transportation and meals) & 4.04 \\
\hline Personal Financials & 3.92 \\
\hline Discretionary time & 3.48 \\
\hline
\end{tabular}

From the results, in addition to the "discretionary time" rating of 3.48, the average score of other items is greater than 3.9 (Table 5.7). This shows that the six factors are all critical for 
the impact of tourist motivation. The most critical influencing factor is "health status" (4.28). This is different with other findings (Hsu, et al. 2007, Huber, et al. 2018) and they all believe that physical health is a very important factor affecting the motivation of the senior tourist. The gradual deterioration of health will cause a decrease in tourism activities for the senior tourist. As Huber, Milne, and Hyde (2018) mentioned, tourism activities that are related to physical stress or have potential health risks like hiking, are usually reduced or abandoned first by the senior tourists.

One unique result is that the researcher finds that the second most important factor affecting the motivation of Chinese senior tourist for day trips is "traffic condition". Most of the literature does not mention this. I think this may be due to the special circumstances of China. China's big cities such as Beijing, Shanghai, Guangzhou has numerous residents, while the quantity of vehicles is even more. This has made traffic congestion a common and irritating phenomenon in big cities in China. The participants in this research are all Beijing residents, so smooth traffic has become another important factor influence their travel.

In this research, "discretionary time" becomes the last of the six factors affecting tourism motivation. This result is inconsistent with the results of Hsu, Cai, and Wong (2007). This may be due to the advancement of the times, and Chinese society is constantly changing. Senior people in China have gradually changed their minds. They used to look after their grandchildren that often cause sacrificing their personal time. Nowadays, they are more willing to take care of both. While helping their children, they will also give themselves time to do some leisure activities.

Therefore, the influencing factors model for the motivation of Chinese senior tourist on day trips is determined (Figure 5.2). 


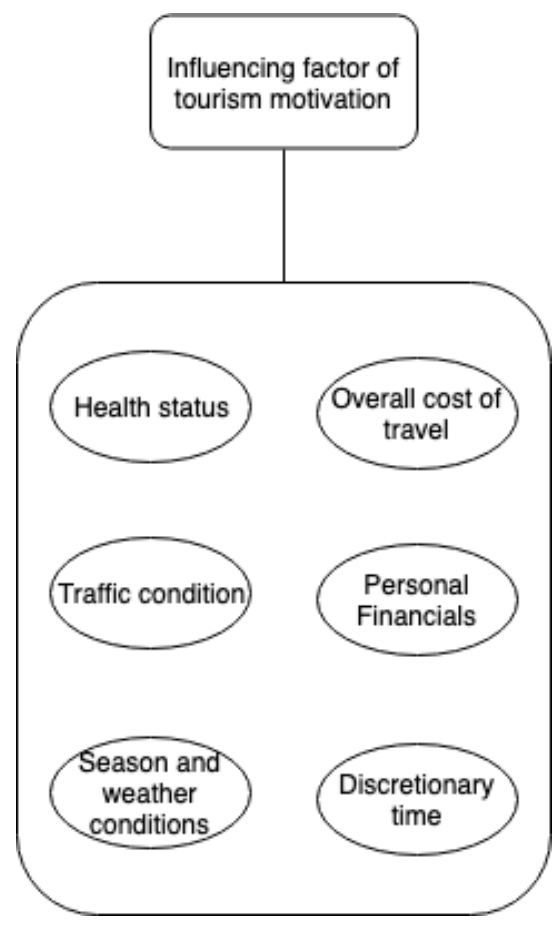

Figure 5.2 Factors influencing tourism motivation

\subsection{Factors influencing tourist satisfaction}

The researcher presented 11 factors have impacts on tourist satisfaction in the questionnaire, and asked participants to propose new influencing factors if they had. The results showed that only one of the 159 people proposed two new influencing factors, service of tourism agency and service of the tourist guide, which were not universal. Therefore, the researcher determines that the influencing factors of tourist satisfaction of Chinese senior tourists for day trips are 11 items (Table 5.8).

The mean value of the score of factors affect tourist satisfaction indicates that for Chinese senior day trips tourists, the three most important influencing factors are: "scenic security" (4.48), "attractive scenery" (4.44), and "service quality of scenic service personnel" (4.40) (Table 5.8). The results validated the findings of Boakye (2012). The results show that in terms of participating in tourism activities, scenic spot safety is the first critical factor affecting the Chinese elderly tourists' satisfaction. This shows that senior people really attach great importance to their personal safety. 
Table 5.8 Factors influencing tourist satisfaction and mean value

\begin{tabular}{|c|c|}
\hline Items & Mean \\
\hline Scenic security & 4.48 \\
\hline Attractive scenery & 4.44 \\
\hline Service quality of scenic service personnel & 4.40 \\
\hline Weather conditions & 4.31 \\
\hline Convenient transport & 4.28 \\
\hline Quality of food and beverage & 4.27 \\
\hline Overall cost of travel (including transportation and meals) & 4.13 \\
\hline Scenic reception capacity & 4.12 \\
\hline Number of tourists in scenic spots & 3.65 \\
\hline The level of participation in activities during the trip & 3.48 \\
\hline Good shopping facilities & 3.33 \\
\hline
\end{tabular}

Older people of different genders will pay different attention to the factors that affect tourist satisfaction (Table 5.9). For male seniors, the most important factor that affects their tourist satisfaction is "attractive scenery". But for the elderly women, the first important factor affecting their travel satisfaction is "scenic security". It can be seen that male elderly people will attach more importance to the attraction of scenic spots, while female elderly people will value the safety of scenic spots more. The results confirmed the results of Boakye (2008). The results show that in participating in tourism activities, older women pay more attention to scenic safety than older men. This may be because of gender impact. Women are more vulnerable than men, so they are more concerned about their own safety. 
Table 5.9 Means of factors influencing tourist satisfaction for different genders

\begin{tabular}{|l|c|c|}
\hline \multicolumn{1}{|c|}{ Factors influencing tourist satisfaction } & Male & Female \\
\hline Attractive scenery & 4.47 & 4.37 \\
\hline Scenic security & 4.45 & 4.56 \\
\hline Service quality of scenic service personnel & 4.38 & 4.46 \\
\hline Weather conditions & 4.27 & 4.40 \\
\hline Convenient transport & 4.23 & 4.40 \\
\hline Quality of food and beverage & 4.20 & 4.44 \\
\hline Scenic reception capacity & 4.11 & 4.15 \\
\hline Overall cost of travel (including transportation and meals) & 4.06 & 4.29 \\
\hline Number of tourists in scenic spots & 3.64 & 3.69 \\
\hline The level of participation in activities during the trip & 3.56 & 3.31 \\
\hline Good shopping facilities & 3.34 & 3.31 \\
\hline
\end{tabular}

Similarly, for senior people of different ages, the same factors have a different influence on their tourist satisfaction (Table 5.10). For the elderly aged 50-55, "Attractive scenery" is the most significant factor influencing tourist satisfaction. For the elderly aged 56-60, the most critical factor influencing tourist satisfaction is "Quality of food and beverage". However, "Scenic security" is the most major factor influence tourist satisfaction for older people over 60 years old. This may be due to the fact that as the age increases, the physical fitness of the elderly will decrease, and the flexibility of the body will become worse and worse. Small bumps may also cause serious damage to the body. Therefore, older people with older ages have higher requirements for the safety of scenic spots. 
Table 5.10 Means of factors influencing tourist satisfaction for different ages

\begin{tabular}{|l|c|c|c|c|c|}
\hline \multicolumn{1}{|c|}{ Factors influencing tourist satisfaction } & $\begin{array}{c}50-55 \\
\text { years } \\
\text { old }\end{array}$ & $\begin{array}{c}56-60 \\
\text { years } \\
\text { old }\end{array}$ & $\begin{array}{c}61-65 \\
\text { years } \\
\text { old }\end{array}$ & $\begin{array}{c}66-70 \\
\text { years } \\
\text { old }\end{array}$ & $\begin{array}{c}\text { Over 70 } \\
\text { years } \\
\text { old }\end{array}$ \\
\hline Attractive scenery & 4.58 & 4.47 & 4.44 & 4.47 & 4.38 \\
\hline Weather conditions & 4.58 & 4.16 & 4.34 & 4.29 & 4.29 \\
\hline Quality of food and beverage & 4.50 & 4.58 & 4.19 & 4.39 & 4.09 \\
\hline Scenic security & 4.42 & 4.21 & 4.56 & 4.63 & 4.45 \\
\hline Scenic reception capacity & 4.33 & 4.21 & 4.13 & 4.13 & 4.03 \\
\hline Number of tourists in scenic spots & 4.17 & 3.68 & 3.75 & 3.42 & 3.64 \\
\hline Convenient transport & 4.17 & 4.16 & 4.28 & 4.32 & 4.31 \\
\hline Service quality of scenic service personnel & 4.08 & 4.42 & 4.50 & 4.39 & 4.41 \\
\hline $\begin{array}{l}\text { The level of participation in activities during } \\
\text { the trip }\end{array}$ & 4.08 & 3.84 & 3.72 & 3.45 & 3.14 \\
\hline $\begin{array}{l}\text { Overall cost of travel (including } \\
\text { transportation and meals) }\end{array}$ & 4.00 & 3.95 & 4.16 & 4.29 & 4.10 \\
\hline Good shopping facilities & 3.92 & 3.58 & 3.69 & 3.61 & 2.76 \\
\hline
\end{tabular}

As for the annual income (Table 5.11), only the elderly with an annual income of more than 200,000 yuan think that the shopping facilities are the most significant factor influence their tourist satisfaction, while the older people with an annual income of less than 20,000 yuan think that the impact of shopping facilities on their tourist satisfaction is very low. This may be because of the fact that the elderly with higher annual incomes have more funds to use and participate in more shopping activities during the travel, so the comfort level of shopping facilities has an important impact on their tourist satisfaction. 
Table 5.11 Means of factors influencing tourist satisfaction for different annual income

\begin{tabular}{|l|c|c|c|c|}
\hline \multicolumn{1}{|c|}{ Factors influencing tourist satisfaction } & $\begin{array}{c}\text { Less than } \\
50,000 \\
\text { CNY }\end{array}$ & $\begin{array}{c}50,001- \\
100,000 \\
\text { CNY }\end{array}$ & $\begin{array}{c}1000,001- \\
200,000 \\
\text { CNY }\end{array}$ & $\begin{array}{c}\text { Over } \\
200,001 C \\
\text { NY }\end{array}$ \\
\hline Attractive scenery & 4.50 & 4.44 & 4.46 & 3.33 \\
\hline Quality of food and beverage & 4.43 & 4.25 & 4.21 & 4.33 \\
\hline Scenic security & 4.40 & 4.47 & 4.61 & 2.67 \\
\hline Weather conditions & 4.37 & 4.25 & 4.36 & 3.67 \\
\hline Service quality of scenic service personnel & 4.30 & 4.42 & 4.45 & 4.00 \\
\hline $\begin{array}{l}\text { Overall cost of travel (including transportation } \\
\text { and meals) }\end{array}$ & 4.27 & 4.17 & 4.04 & 4.00 \\
\hline Convenient transport & 4.23 & 4.29 & 4.33 & 3.33 \\
\hline Scenic reception capacity & 4.23 & 4.10 & 4.09 & 4.00 \\
\hline Number of tourists in scenic spots & 4.00 & 3.54 & 3.61 & 3.33 \\
\hline Good shopping facilities & 3.53 & 3.10 & 3.40 & 4.33 \\
\hline $\begin{array}{l}\text { The level of participation in activities during the } \\
\text { trip }\end{array}$ & 3.47 & 3.31 & 3.64 & 3.67 \\
\hline
\end{tabular}

The 11 influencing factors of tourist satisfaction are divided into three categories by factor analysis, which are "tour related dimensions", "the environmental factor", and "experience and perception of tourist". "Tour related dimensions" category includes "attractive scenery", "scenic security", "service quality of scenic service personnel", and "overall cost of travel (including transportation and meals)". "The environmental factor" category includes "convenient transport", "weather conditions", "number of tourists in scenic spots", and "scenic reception capacity". "Experience and perception of tourist" category includes "good shopping facilities", "quality of food and beverage", and "the level of participation in activities during the trip". For Chinese senior day trips tourists, the most important influencing factors of tourist satisfaction category is "tour related dimensions" (mean=4.36) (Table 5.12).

Table 5.12 The mean of the factor categories influencing tourist satisfaction

\begin{tabular}{|c|c|c|c|}
\hline Categories & Tour related dimensions & $\begin{array}{c}\text { The environmental } \\
\text { factor }\end{array}$ & $\begin{array}{c}\text { Experience and } \\
\text { perception of tourist }\end{array}$ \\
\hline Mean & 4.3648 & 4.0896 & 3.6960 \\
\hline
\end{tabular}


The results are consistent with Huang and Hsai (2003), that is the important factor affecting tourist satisfaction are tourism-related dimensions, such as visit beautiful scenery, quality of food and beverage. Consistent with the results of Kim, Woo, and Uysal (2015), the results of this study show that visitors' experiences and perceptions have an impact on the tourist satisfaction of day trips senior tourists in China. This shows that in addition to the scenery that attracts tourists, the activities during the tour and the facilities used by the tourists are also very important.

The results show that the most critical factor affecting the tourist satisfaction of day trips senior tourists in China is "the security of scenic spots". Compared with young people, the physical ability of the elderly is generally inevitable. The same bump or fall can have more serious consequences for the elderly than younger people. This means that the risk in the travel process increases. Because of aging, the physical recovery ability of the elderly is also much less than that of young people, so for the senior tourists, the safety of the scenic spot is the most important.

Therefore, the influencing factors model for the satisfaction of Chinese senior tourist on day trips is determined (Figure 5.3).

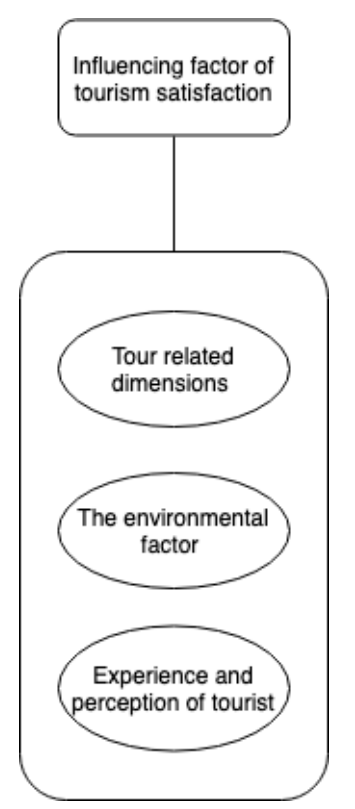

Figure 5.3 Factors influencing tourist satisfaction 


\subsection{Relationships among tourism motivation, tourism expectation, tour quality, tourist satisfaction, and tourists' future behavioural intention}

The results of this research show the tourist motivation affect the tour quality positively. The result is the same as the finding of Lee, Jeon, and Kim (2010). As tourist motivation becomes higher, tourists evaluate their tour quality better. Therefore, local governments and tourism agencies should strive to find the interest and demand of the elderly for tourism and stimulate their enthusiasm for tourism, which may allow more potential tourists to participate more actively in tourism activities.

Tourists can compare the tourism expectation before the tour with their experience after the tour to determine the quality of the tour. Contrary to the conclusions of Lee, Jeon, and Kim (2010), this research found that the tourism expectation of Chinese day trips senior tourists has a significantly positive influence on tour quality, which means, as the tourist expectation for the tour becomes greater, the tour quality increases. In the study by Lee, Jeon, and Kim (2010), the Chinese tourists' tourism expectation for South Korea depends mainly on salespeople's recommendations and market information. Therefore, the tourism expectation of tourists is uncertain, and the overly high expectations may cause disappointment for tourists. However, in this research, all participants are local residents of Beijing who are familiar and aware of the vast amount of information in and around the city where they lived. Therefore, they do not produce excessively unrealistic expectations. This means that most of the tourists' expectation could be met, and thus can obtain good experience.

The research results show tour quality affects tourist satisfaction positively, which is consistent with the finding of Lee, Jeon, and Kim (2010). Kim, Woo, and Uysal (2015) also found that the perceptual assessment of traveller's travel experience has a positive influence on travel satisfaction. This means as the tour quality becomes higher, the tourist satisfaction increases. In addition, variables including health status, marital status, education, age, gender, and annual income, won't affect the satisfaction of Chinese senior tourists. Meanwhile, the research results also demonstrate that the relationship between 
tourist satisfaction and tourism motivation can be partially mediated by tour quality, which is able to mediate the relationship between tourist satisfaction and tourism expectation completely. This shows tour quality is a very important link in improving the tourist satisfaction of tourists. The government and travel agencies should attach more importance to this link and strive to increase the tourist satisfaction of tourists, so relevant departments and the local government should propose strong countermeasures regarding the improvement of the quality of tourism services.

Results show that tourist satisfaction has a significantly negative regression weight on tourists' future behavioural intention, indicating as the tourist satisfaction becomes higher, the tourists' future behavioural intention decreases. Meanwhile, the mean value of the two variables in tourists' future behavioural intent shows as the tourist satisfaction of tourists becomes higher, the possibility that they recommend the tourist activity to others increases (Table 4.3). Conversely, as the tourist satisfaction of tourists becomes higher, the probability that they will complain to others about the travel activity decreases (Table 4.3). This result is supporting Lee, Jeon and Kim (2010) who found that as the satisfaction of Chinese tourists in South Korea becomes lower, the complaint rate increases. Therefore, the tourism practitioner should work to increase the tourist satisfaction of senior tourists to reduce complaints about dissatisfaction after the trip.

\subsection{Model}

According to all the research results, the model of motivation and satisfaction for the Chinese senior tourists on day trips is determined (Figure 5.4). 


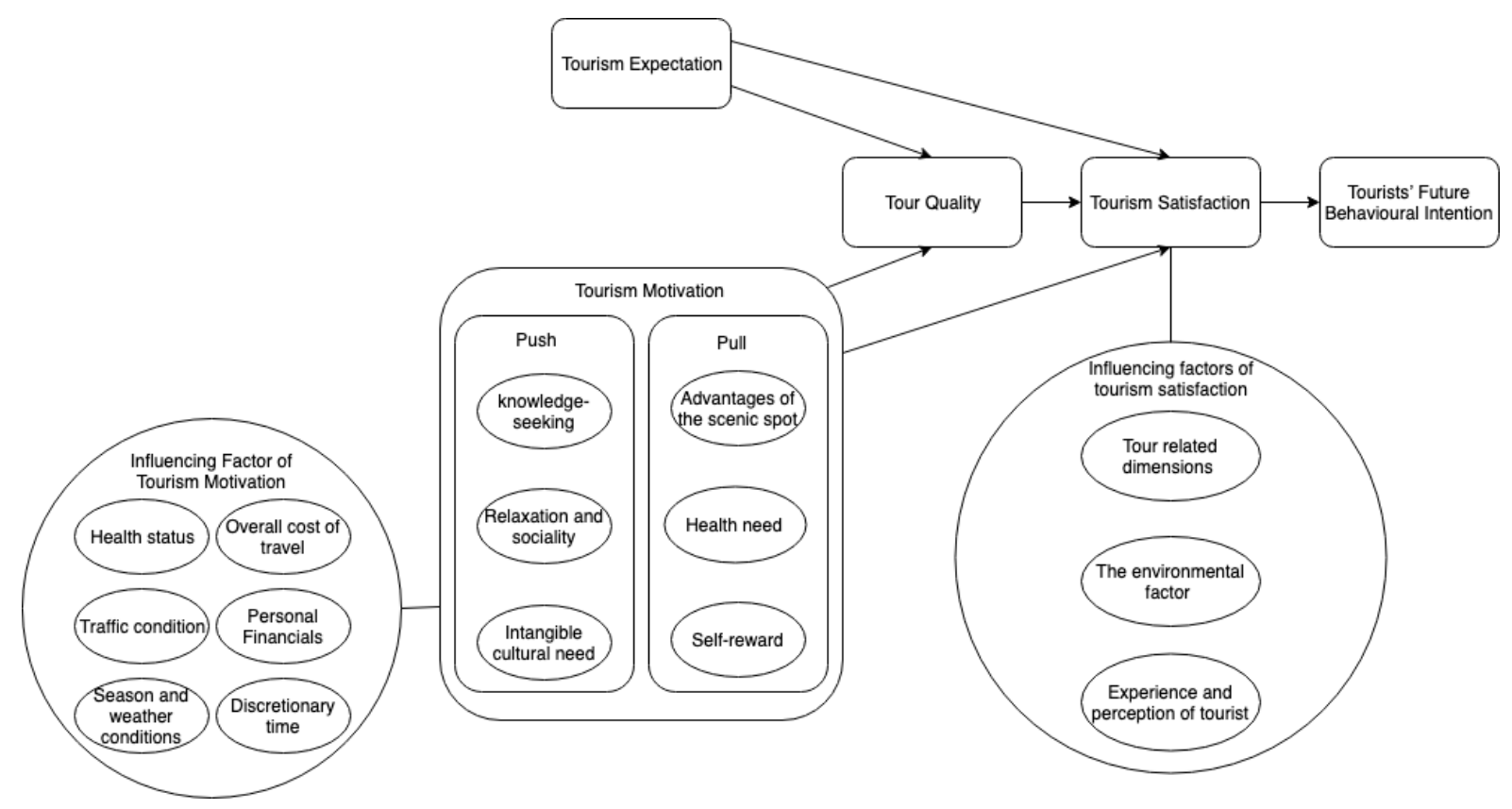

Figure 5.4 The model of tourist motivation and satisfaction for the Chinese senior tourists on day trips.

As shown in figure 5.4, the model includes tourist motivation, influencing factors of tourist motivation, tourism expectation, tourist satisfaction, tour quality, factors affecting tourist satisfaction, and the tourists' future behavioural intention. Among them, tourist motivation and tourism expectation affect tour quality positively. Tour quality will influence tourist satisfaction positively, and tourist satisfaction has a significant negative influence on the future behavioural intentions of tourists. Tourist motivation includes two categories, which are push motivation and pull motivation. Six factors will influence the tourist motivation. The factors affect the tourist satisfaction includes three categories. 


\section{Chapter 6 Conclusion}

\subsection{Introduction}

The purpose of this chapter is to summarize the process and all the results of the research and to summarize the contributions and significance of the study to complete the study. At the end of the chapter, suggestions will provide for future tourism motivation and satisfaction of senior tourists.

\subsection{Summary of the research}

The main purpose of the research is to identify the model of tourists' satisfaction and motivation of the Chinese senior visitors on day trips. In order to achieve the purpose, the study responded to the research question: "What are the factors that determine the satisfaction and motivation of Chinese senior tourists on day trips?" The study uses the quantitative research method of the positivist paradigm to conduct the research. The study investigated the tourism motivation and satisfaction of day trips for local senior citizens in Beijing, China. With the participation of 165 elderly residents in Beijing, the research was conducted smoothly and the research results were obtained.

The research results identified 12 push tourism motivations and 7 pull tourism motivations. There are three categories for the push tourism motivations, which are "relaxation and sociality", "knowledge-seeking", and "intangible cultural need", and three categories for the pull tourism motivations, which are "self-reward", "advantages of the scenic spot", and "health need". The results also show that the two most important push motivations are: "there are some places I have always wanted to visit", and "I want to see the things that I don't normally see". The two most important pull motivations are "outstanding scenery", and "historical sights". However, the importance of tourism motivation for senior people with different characteristics is also different. For example, senior males are more likely to be attracted to beautiful scenery or historical attractions, while senior females prefer delicious food and shopping. The elderly aged 50-55 think that fitness is also an important reason for travel, and for people above 55 years old, fitness is not an important reason for 
tourism. Older people with a doctoral degree or higher is more inclined to meet the needs of intangible culture than others and are more willing to participate in cultural activities. One of the important reasons for the elderly who have an annual income of more than $200,000 \mathrm{CNY}$ is to participate in special activities like worshipping Buddha or praying for luck.

The influencing factors of tourism motivation of Chinese senior tourists for day trips are 6 factors, which are "health status", "traffic condition", "season and weather conditions", "the overall cost of travel (including transportation and meals)", "personal Financials", "discretionary time". Health status is the most important factor influencing the participation of senior people in tourism activities. As people grow older, the health of older people will gradually deteriorate, and physical flexibility will also worsen, which will limit the travel of the elderly. Different from other literature, the results of this study show that another important influencing factor is traffic condition. Traffic congestion in large cities in China is very common. As participants of this study are local residents in Beijing, traffic condition has become another important factor affecting their tourism motivation.

There are 11 influencing factors of tourist satisfaction of Chinese senior tourists for day trips, and they are divided into three categories by factor analysis, which are "tour related dimensions", "the environmental factor", and "experience and perception of tourist". As with tourism motivation, people with different characteristics will pay different attention to the factors that affect their tourist satisfaction. Female elderly people value the safety of scenic spots more than male elderly. senior people over the age of 60 are also more concerned about the safety of the scenic spot than older people aged 50-60. The elderly with an annual income of more than 200,000 CNY will pay more attention to shopping facilities than others.

Furthermore, the results also show as the tourism motivation becomes higher, the assessment of the tour quality by the Chinese elderly increases. Similarly, as the tourism expectation becomes higher, the assessment of the tour quality by Chinese senior people increases. As the tour quality becomes higher, tourist satisfaction better. Tourist satisfaction affects the Chinese elderly tourists' future behavioural intention negatively. Meanwhile, the 
mean value of tourists' future behavioural intention variables shows as the tourist satisfaction of the Chinese elderly becomes higher, they tend to recommend the tourism activities to their friends. As the tourist satisfaction of the Chinese elderly becomes lower, they tend to complain to their friends.

\subsection{Implications}

\subsubsection{Academic implications}

This research is academically helpful to fill the gap in the study of Chinese senior tourists on day trips. Although there are many kinds of literature on day trips and the motivation and satisfaction of tourism for senior tourists, most of the literature on China's day trips is to study how to eliminate the illegal travel services provided during the day trip. This study attempts to explore the tourist motivation and satisfaction of Chinese seniors who participate in day trips. From this unique perspective, this research conducts an empirical study to determine the model of tourist motivation and satisfaction of the Chinese senior tourists on day trips and provides some suggestions for Chinese policymakers and tourism practitioners according to the results.

The research validated a few the previous research results in this field, confirmed most of the research results, denied a few, and had some new findings. For Chinese senior tourists on day trips, the most important push motivation category is "knowledge-seeking". This result is consistent with other research findings (Zhang \& Lam, 1999, Horneman et al., 2002, Jang \& Wu, 2006). They all believe that "knowledge-seeking" is the most significant tourism motivation for the elderly tourists. However, this is dissimilar from the findings of Huang and Tsai (2003), who find that "rest and relaxation" is the most major tourism motivation for seniors in Taiwan. For pull motivation, the study found that Chinese senior tourists on day trips are like beautiful scenery and historical attractions most. This result validates the findings of Huang and Tsai (2003), who found that elderly people in Taiwan also more and more attracted to history and beautiful attractions. In contrast to this view, Jang and Wu (2006) found the most significant pull motivation for seniors in Taiwan is "cleanliness \& safety". A unique finding of the study is that "traffic condition" is an important factor 
influencing the tourist motivation of Chinese elderly people. This is related to the widespread traffic congestion in China's big cities. City residents usually take day trips in or around the city, so traffic conditions are especially important for Chinese tourists on day trips. The study also confirmed the findings of Huang and Hsai (2003) that tourism-related dimensions are important factors influencing tourist satisfaction.

The study also found the demographic characteristics of senior tourists have an impact on their travel motivation and influencing factors of tourist satisfaction. The important factor in the tourism activities participation of male seniors is sharing travel experiences with family or friends. For senior women, it is more important to satisfy curiosity. In addition, older male tourists prefer beautiful scenery and historical attractions, while older female tourists are attracted to food and shopping. Regarding tourist satisfaction, male seniors attach more importance to the attraction of scenic spots, while female elderly people value the safety of scenic spots more. Furthermore, as the age continues to grow, the reason for older people participate in tourism activities is more likely to be to visit the scenery than to exercise. For the elderly aged 50-55, the most important thing is to see the beautiful scenery. Quality of food and beverages is most important for older people aged 56-60. However, people over 60 years old most value the safety of the scenic area. Older people with more knowledge will pay more attention to the needs of intangible culture. Participating in cultural events, and gaining new experiences are important factors in attracting them to participate in tourism activities. senior people with an annual income of more than 200,000 yuan will be attracted to food, special events or attractions, and they will attach more importance to communicate with family and friends the experience of their journey. Moreover, only the elderly with an annual income of more than 200,000 yuan think that shopping facilities are very important to their tourist satisfaction.

The findings also validate the relationship among tourist expectation, tourist motivation, tour quality, tourist satisfaction, and the future behavioural intention of tourist. Tourist motivation and expectation affect tour quality positively. Tour quality affect the tourist satisfaction positively. Tourist satisfaction affect tourists' future behavioural intentions negatively. These results are consistent with previous literature (Huang \& Hsai, 2003, Lee et al., 2010, Kim et al., 2014). However, Lee, Jeon, and Kim (2010) found that tourism 
expectation has a negative impact on tour quality, which is inconsistent with the results of this study. This probably because of the research (Lee et al., 2010) samples are Chinese participating in outbound travel, and tourists may not have complete information on destination, leading to an excessive expectation of tourist. When the expectation is not met, the evaluate of the tour quality will be reduced by the tourist.

\subsubsection{Practical implications}

The ability of the travel destination to provide excellent products that satisfy the visitors' requirements determines the future development of the tourism market (Jayawardena, 2002). To develop a marketing strategy, travel practitioners are required to measure customer satisfaction in travel products. Therefore, the analysis of target visitors helps evaluate the factors affect the marketing strategy of the destination, thereby enhancing their competitiveness (Ibrahim, \& Gill, 2006). As the development of the population aging, the elderly market has grown fast. Therefore, understanding the purpose of senior people participating in tourism activities, their demand and satisfaction are very important for the tourism industry.

When developing tourism products, we should emphasise the market concept and consider the market demands at the beginning of the development of tourism products. Neglecting market demand for tourism product development neither can design attractive tourism products nor using tourism resources efficiently (Han, \& Cong, 2006).

Therefore, tourism companies should aim at the most important tourism push motivation for Chinese day trips senior tourists, that is, knowledge seeking, develop more new tourism activities or tour routes, and strive to improve the interest of local senior tourists in the surrounding scenic spots and enhance their freshness and curiosity about new travel products. For example, in recent years, forest tourism activities have attracted more and more attention from Chinese consumers. Forest recreational tourism mainly based on elderly recuperation is a fresh kind of tourism product, which is in its infancy. Tourism enterprises should develop it as soon as possible to satisfy the growing senior tourists' requirements. 
In order to enhance the tourism enthusiasm of the elderly, the government should improve the construction of barrier-free tourism facilities and transportation, accommodation, scenic spots, and provide relevant training for the personnel's accessibility awareness and skills within the scenic spot, and try to create barrier-free tourism environment for the senior tourists.

Regarding the traffic conditions that tourists concerned, the government can improve the vehicle dispatch management between the city and the scenic spot, reasonably design the tour bus lines, and increase the transfer bus, shuttle bus, and increase the hot bus line in time. The scenic spot can appropriately increase the "best route recommendation" and other information to release to make tourists more aware of tourism route selection, try to make tourists do not go back and achieve the purpose of diversion. For self-driving tourists, improve the tourist destination guidance, and plan the construction of parking spaces, so that they will have enough parking spaces and can reasonable park (Shihuajiangnan tourism planning and design institute, 2018).

In order to increase the safety of the scenic spot, the employee of scenic spots should regularly inspect, repair and maintain the visiting facilities such as ropeways, sightseeing ladders, cruise ships, etc. so that they can meet the national safety standards, and accurately verify the number of passengers, the weight of the passengers, the running speed, etc., and strictly enforce them. The scenic spot should provide systematic safety education and training for their employees, and truly improve the safety consciousness and management level of employees.

\subsection{Limitations and recommendations for future research}

This study was conducted within the boundaries of the positivist paradigm and using nonrandom sampling methods for quantitative analysis. However, a social constructivist paradigm would explore some of the concepts raised in this research through explorative interviews in order to study deeply through the use of interviews. Anthropological research can also be considered in future research. This study can be used for the beginning of an 
anthropological study to study the behaviours and motivations of senior residents in some long-term research.

Due to limited resources, the number of research samples in this study is small. In future studies using quantitative analysis, the sample size should be increased to increase the reliability of the study.

This study was using a voluntary sample survey methodology. Participants are university retirees mostly, so the study does not cover most industries in terms of occupational distribution, which has a certain impact on the universality of the analysis results. Simultaneously, the study did not control the number of different demographic characteristics in the samples, resulting in an uneven ratio of males and females in the samples. In future research, the number of different demographic characteristics in the sample should be controlled and the occupations should be covered to make the research results universal.

In addition, the participants in the study were all from Beijing residents. For China, Beijing residents only account for a small portion of the population. In order to fully study the tourist motivation and satisfaction of Chinese senior tourists on day trips, in future research, random sampling surveys should be conducted in various regions of China to try to cover various types of people.

Furthermore, due to the time, this study does not delve inside the impact of demographic characteristics on tourist motivation and satisfaction of Chinese senior tourists. It should strengthen study in these parts to be able to fully comprehend the tourist motivation and satisfaction of Chinese senior tourists on day trips in future research.

\subsection{Conclusion}

In summary, the research explored the Chinese senior tourists' satisfaction and tourism motivation on day trips. By using non-random sampling method in positivism, the research answered the question: "What are the factors that determine the satisfaction and 
motivation of Chinese senior tourists on day trips?" and identified the model of Chinese senior tourists' satisfaction and tourism motivation on day trips.

The government should strengthen the publicity of the city and its surrounding attractions, and strengthen the governance of the traffic congestion situation of the city and surrounding scenic spots. The government should also improve tourism infrastructure, improve tourism public services, and optimize the tourism environment. Travel agencies should establish good travel service standards to increase the service quality. In addition, relevant government departments and travel agencies should open up channels for customer service complaints and provide tourists with convenient ways to complain. 


\section{References}

"Aging of Population." Encyclopedia of Population. Retrieved April 29, 2019, from Encyclopedia.com: https://www.encyclopedia.com/social-sciences/encyclopediasalmanacs-transcripts-and-maps/aging-population

Babbie, E. R. (2013). The Practice of Social Research (13th). Belmont, Calif: Wadsworth Cengage Learning

Baker, D. A., \& Crompton, J. L. (2000). Quality, satisfaction and behavioral intentions. Annals of Tourism Research, 2000, Vol.27(3), pp.785-804. DOI: 10.1016/S0160-7383(99)00108-5

Balderas-Cejudo, A., Patterson, I., \& Leeson, G. W. (2019). Senior Foodies: A developing niche market in gastronomic tourism. International Journal of Gastronomy and Food Science, Volume 16, July 2019, 100152

Baron, R. M., \&Kenny, D. A. (1986). The moderator-mediator variable distinction in social psychological research: Conceptual, strategic, and statistical considerations. Journal of Personality and Social Psychology, 51, 1173-1182.

Beijing statistics bureau. (2017). The outline of Beijing tourism statistics. Retrieved from http://data.cnki.net/yearbook/Single/N2017050181

Bigné, J.E., Sánchez, M.I., \& Sánchez, J. (2001). Tourism image, evaluation variables and after purchase behaviour: inter-relationship. Tourism Management, 2001, Vol.22(6), pp.607-616. DOI: 10.1016/S0261-5177(01)00035-8

Blaikie, N. (2003). Analyzing Quantitative Data from Description to Explanation. London, UK: SAGE. 
Boakye, K. A. (2008). The concept of capable guardianship: Exploring police views on tourist protection in Ghana. Crime Prevention and Community Safety, Apr 2009, Vol.11(2), pp.104123. DOI: $10.1057 /$ cpcs. 2008.23

Boakye, K. A. (2012). Tourists' views on safety and vulnerability. A study of some selected towns in Ghana. Tourism Management, April 2012, Vol.33(2), pp.327-333

Botterill, D. \& Platenkamp, V. (2012). Key Concepts in Tourism Research. London: Thousand Oaks, California: SAGE Publications Ltd

Bowen, D., \& Clarke, J. (2009). Contemporary tourist behaviour: yourself and others and tourists / David Bowen and Jackie Clarke. Wallingford, UK; Cambridge, MA: CABI

Bromley, D.B. (1990). Behavioural gerontology: central issues in the psychology of ageing. Wiley, West Sussex, England

Cai, Y. J. (n.d.). Strategy to improving the quality of tourism service. Retrieved April 12, 2019, from https://www.xchen.com.cn/gllw/fwzllw/696184.html

Chen, L., \& Zhao, J. (2018). Tourism safety in scenic spots urgently need complete legislation because of numerous safety incidents. Retrieved April 12, 2019, from http://www.xinhuanet.com/legal/2018-11/26/c_1123764895.htm

China Industry Information. (2018). Analysis of the State and Development Trend of China's Tourism Industry in 2018. Retrieved from http://www.chyxx.com/industry/201804/634265.html

China National Committee on Ageing. (2015). China's economic demographic map the ageing of its population is accelerating. Beijing Business Today. 2015. Retrieved from http://www.cncaprc.gov.cn/contents/37/69715.html 
China statistics bureau. (2017). China statistical yearbook. Retrieved from http://www.stats.gov.cn/tjsj/ndsj/2017/indexch.htm

Cortina, J. M., \& Schmitt, N. (1993). What Is Coefficient Alpha? An Examination of Theory and Applications. Journal of Applied Psychology, 1993, Vol.78(1), pp.98-104. DOI: 10.1037/0021-9010.78.1.98

Cronin, J., \& Taylor, S. (1992). Measuring service quality: a reexamination and extension. Journal of Marketing, Jul 1, 1992, Vol.56(3), p.55

David, E. B., David, C., \& Günter, F. (2011). Implications of population aging for economic growth. PGDA Working Papers 6411, Program on the Global Demography of Aging. 2011.

Day, R. L., \& Landon, E. L., Jr. (1977). Towards a theory of consumer complaining behavior. In A. Woodside, J. Sheth, \& P. Bennett (Eds.), Consumer and industrial buying behavior. Amsterdam: North-Holland Publishing Company, ISBN 0444002308. - 1977, p. 425-437

Easterby-Smith, M. (2008). Management research; an introduction, 3rd ed. London: SAGE

Euromonitor. (2013). Harnessing the Power of the Older Consumer. Retrieved from http://www.portal.euromonitor.com.helicon.vuw.ac.nz/portal/analysis/tab

Fleischer, A. \& Pizam, A. (2002). Tourism constraints among Israeli seniors. Annals of Tourism Research, 29 (1) (2002), pp. 106-123. DOI: 10.1016/S0160-7383(01)00026-3

Fodness, D. (1994). Measuring tourist motivation. Annals of Tourism Research, 21 (1994), pp. 555-581. DOI: 10.1016/0160-7383(94)90120-1

Gao, Z. F. (2018). Research on the Problems and Countermeasures of the Development of the Senior Tourism Market. Modern Economic Information. 2018, Vol. 04. ISSN : 1001-828X 
Gartner, W. C. (1989). Tourism Image: Attribute Measurement of State Tourism Products Using Multidimensional Scaling Techniques. Journal of Travel Research, October 1989, Vol.28(2), pp.16-20. DOI: 10.1177/004728758902800205

Gilbert, D., \& Abdullah J. (2004). Holiday taking and the sense of well-being. Annals of Tourism Research, Vol.31 (1), January 2004, pp. 103-121

Goggin, J. M. (1999). Elderhostel Meets the Silent Revolution. Tourism Recreation Research, 01 January 1999, Vol.24(1), p.86-89. DOI: 10.1080/02508281.1999.11014863

Guinn, R. (1980). Elderly Recreational Vehicle Tourists: Motivations for Leisure. Journal of Travel Research, July 1980, Vol.19(1), pp.9-12. DOI: 10.1177/004728758001900102

Hair, J. F., Black, W. C., Babin, B. J. \& Anderson, R. E. (2013). Multivariate data analysis (Seventh Edition). Pearson Education Limited, Harlow, United Kingdom.

Han, Y., \& Cong, Q. (2006). Tourism Marketing. Beijing: Peking University Press. Horneman, L., Carter, R.W., Wei, S., \& Ruys, H. (2002). Profiling the senior traveler: An Australian perspective. Journal of Travel Research, 41 (2002), pp. 23-37. DOI: $10.1177 / 004728750204100104$

Horng, J., \& Tsai, C. (2010). Government websites for promoting East Asian culinary tourism: A cross-national analysis. Tourism Management. Vol.31, Issue 1, February 2010, pp. 74-85

Hsu, C. H. C., Cai, L. A., \& Wong, K. K. F. (2007). A model of senior tourism motivationsAnecdotes from Beijing and Shanghai. Tourism Management, 2007, Vol.28(5), pp.12621273. DOI: 10.1016/j.tourman.2006.09.015

Huang, L., \& Tsai, H. (2003). The study of senior traveler behavior in Taiwan. Tourism Management, 2003, Vol.24(5), pp.561-574. DOI: 10.1016/S0261-5177(03)00008-6 
Huber, D., Milne, S., \& Hyde, K. F. (2018). Constraints and facilitators for senior tourism. Tourism Management Perspectives, July 2018, Vol.27, pp.55-67. DOI: 10.1016/j.tmp.2018.04.003

Hu, X. M. (2017). The Problem of Existence and Development of Senior Tourist Market in China. Jiangsu Commercial Forum. 2017, Vol. 07. ISSN : 1009-0061

Jang, S. C. \& Wu, C. M. (2006). Seniors' travel motivation and the influential factors: An examination of Taiwanese seniors. Tourism Management, April 2006, Vol.27(2), pp.306-316. DOI: 10.1016/j.tourman.2004.11.006

Jiang, M. W. (2019). Forest tourism encounters product development bottleneck during the rising period. Retrieved April 12, 2019, from http://www.bbtnews.com.cn/2019/0213/285979.shtml

Kapborg, I., \& Bertero, C. (2001). Using an interpreter in qualitative interviews: does it threaten validity? Nursing Inquiry, Vol. 9 (1), pp. 52-56.

Kim, H., Woo, E., \& Uysal, M. (2015). Tourism experience and quality of life among elderly tourists. Tourism Management, February 2015, Vol.46, pp.465-476. DOI:

10.1016/j.tourman.2014.08.002

Kozak, M. \& Rimmington, M. (2000). Tourist Satisfaction with Mallorca, Spain, as an OffSeason Holiday Destination. Journal of Travel Research, February 2000, Vol.38(3), pp.260269. DOI: $10.1177 / 004728750003800308$

Kreis, H., \& Mafael, A. (2014). The influence of customer loyalty program design on the relationship between customer motives and value perception. Journal of Retailing and Consumer Services, July 2014, Vol.21(4), pp.590-600. DOI: 10.1016/j.jretconser.2014.04.006 
Landon, E. (1980). The direction of consumer complaint research. In J. C. Olson (Ed.), Advance in Consumer Research, 7 (pp. 335-338).

Lee, S., Jeon, S., \& Kim, D. (2010). The impact of tour quality and tourist satisfaction on tourist loyalty: The case of Chinese tourists in Korea. Tourism Management, October 2011, Vol.32(5), pp.1115-1124. DOI: 10.1016/j.tourman.2010.09.016

Lehto, X. Y., Chen, S. Y., \& Silkes, C. (2014). Tourist shopping style preferences. Journal of Vacation Marketing, January 2014, Vol.20(1), pp.3-15. DOI: 10.1177/1356766713484727

Lin, Y., Pearson, T.E., \& Cai, L.A. (2011). Food as a form of Destination Identity: A Tourism Destination Brand Perspective. Tourism and Hospitality Research, January 2011, Vol.11(1), pp.30-48

Mann, Prem S. (2010). Introductory Statistics (7th Revised edition). USA: John Wiley \& Sons Ltd.

Martin, A. J., Ginns, P., \& Papworth, B. (2017). Motivation and engagement: Same or different? Does it matter? Learning and Individual Differences, April 2017, Vol.55, pp.150162. DOI: 10.1016/j.lindif.2017.03.013

Martin, A.J. (2007). Examining a multidimensional model of student motivation and engagement using a construct validation approach. British Journal of Educational Psychology, June 2007, Vol.77(2), pp.413-440. DOI: 10.1348/000709906X118036

Martin, A.J. (2009). Motivation and Engagement Across the Academic Life Span: A Developmental Construct Validity Study of Elementary School, High School, and University/College Students. Educational and Psychological Measurement, October 2009, Vol.69(5), pp.794-824. DOI: 10.1177/0013164409332214

Mill, R. C. \& Morrison, A. M. (1985). The tourism system: An introductory text. Prentice Hall, Englewood Cliffs, NJ 
Moisey, R. N., \& Bichis, M. (1999). Psychographics of Senior Nature Tourists: The Katy Nature Trail. Tourism Recreation Research, 01 January 1999, Vol.24(1), p.69-76. DOI: $10.1080 / 02508281.1999 .11014859$

Mook, D.G. (1996). Motivation: the organization of action (2nd ed.). W.W. Norton \& Company, New York

Moscardo, G., \& Green, D. (1999). Age and Activity Participation on the Great Barrier Reef. Tourism Recreation Research, 01 January 1999, Vol.24(1), p.57-68.

DOI: $10.1080 / 02508281.1999 .11014858$

Moscardo, G. (2004). Shopping as a destination attraction: An empirical examination of the role of shopping in tourists' destination choice and experience. Journal of Vacation Marketing, October 2004, Vol.10(4), pp.294-307

Moutinho, L. (1987). Consumer Behaviour in Tourism. European Journal of Marketing, 01 October 1987, Vol.21(10), pp.5-44. DOI: 10.1108/EUM0000000004718

Moutinho, L. (2000). Strategic management in tourism. CABI Publishing, New York

Muller, T. E. \& Strickland, C. D. (1995). Educational and adventure tourism for older adults: Assessing the potential. In D. H. Sogar \& I. Weber (Eds.), Proceedings of the Marketing Educators and Researchers International Conference (pp. 656-663). Gold Coast, Australia: Griffith University.

Neal, J., Sirgy, M., \& Uysal, M. (1999). The role of satisfaction with leisure travel/tourism services and experience in satisfaction with leisure life and overall life. Journal of Business Research, Vol.44 (3) (1999), pp. 153-163

Neal, J., Uysal, M., \& Sirgy, M. (2007). The effect of tourism services on travelers' quality of life. Journal of Travel Research, Vol.46 (2) (2007), pp. 154-163 
O'Leary, Z. (2017). The essential guide to doing your research project (3rd edition). London: Thousand Oaks, California: SAGE Publications Ltd

Parasuraman, A., Zeithaml, V. A., \& Berry, L. L. (1985). A conceptual model of service quality and its implications for future research. Journal of Marketing, Fall 1985, Vol.49(4), p.41

Parasuraman, A., Zeithaml, V. A., \& Berry, L. L. (1990). Delivering service quality. The Free Press, New York

Qian, C. X. (2012). Consumer satisfaction is the lifeblood of tourism. Retrieved from http://travel.sohu.com/20120521/n343681920.shtml

Qin, L. N., Xu, J. F. (2012). The Causes and Countermeasures of the "One-day Tour" Problem in Beijing - The Transition from Tourism Industry Management to Tourism Public Service. China Business \& Trade, 2012, Vol. 13

Rong, F. Q., \& Zhang, X. Y. (2006). Population Ageing and New Ddevelopment of Tourism for Older Persons in China. Xibei Population. 2006, Vol. 04. DOI: 10.15884/j.cnki.issn.10070672.2006.04.019

Shihuajiangnan tourism planning and design institute. (2018). How to improve the tourist satisfaction of the scenic spot? Retrieved April 12, 2019, from https://xw.qq.com/cmsid/20180104B0N46E00

Sirgy, M. J., \& Lee, D.J. (2006). Macro measures of consumer well-being (CWB): a critical analysis and a research agenda. Journal of Macro marketing, 26 (1) (2006), pp. 27-44

Sirgy, M. J., Kruger, P.S., Lee, D.J., \& Grace, B.Y. (2011). How does a travel trip affect tourists' life satisfaction? Journal of Travel Research, 50 (3) (2011), pp. 261-275 
Spreng, R.A., ManKenzie, S.B., \& Olshavsky, R.W. (1996). A Re-examination of the determinants of consumer satisfaction. Journal of Marketing, 60 (3) (1996), pp. 15-32

Stetic, S., Simicevic, D., \& Stanic, S. (2011). Same-day trips: A chance of urban destination development. UTMS Journal of Economics, ISSN 1857-6982, University of Tourism and Management, Skopje, Vol. 2, Iss. 2, pp. 113-124

Tabachnick, B. G., \& Fidell, L. S. (2013). Using Multivariate Statistics (6th edition). Boston: Pearson.

The National People's Congress of the People's Republic of China. (1978a). Interim Measures of the State Council on Workers' Retirement and Resignation. Retrieved from http://www.npc.gov.cn/wxzl/wxzl/2000-12/07/content_9552.htm

The National People's Congress of the People's Republic of China. (1978b). Interim Measures of the State Council on the Resettlement of Old, Weak, Sick and Disabled Cadres. Retrieved from

http://101.mca.gov.cn/article/zcfg/flfg/200812/20081200023105.shtml

Tribe, J. \& Snaith, T. (1998). From SERVQUAL to HOLSAT: holiday satisfaction in Varadero, Cuba. Tourism Management, 1998, Vol.19(1), pp.25-34. DOI: 10.1016/S02615177(97)00094-0

Trochim, W. M. K. (2006). Descriptive statistics. Research Methods Knowledge Base. Retrieved 14 March 2011, from http://www.socialresearchmethods.net/kb/statdesc.php

Tse, D.K., \& Wilton, P.C. (1988). Models of consumer satisfaction formation: An extension. Journal of Marketing Research, 25 (1988), pp. 204-212

United Nations, Department of Economic and Social Affairs, Population Division (2017). World Population Ageing 2017. Retrieved from 
https://www.un.org/en/development/desa/population/publications/pdf/ageing/WPA2017_ Report.pdf

United Nations, Department of Economic and Social Affairs, Population Division (2017). World Population Prospects: The 2017 Revision, Key Findings and Advance Tables. $E S A / P / W P / 248$. Retrieved from https://esa.un.org/unpd/wpp/Publications/Files/WPP2017_KeyFindings.pdf

Uysal, M., Sirgy, J., Woo, E., \& Kim, H. (2016). Quality of life (QOL) and well-being research in tourism. Tourism Management, April 2016, Vol.53, pp.244-261. DOI: 10.1016/j.tourman.2015.07.013

Victoria University of Wellington. (2018). Human Ethics Policy. Retrieved from https://www.victoria.ac.nz/documents/policy/research-policy/human-ethics-policy.pdf Wang, D., Liu, X., \& Lin, X. Q. (2013). Main Countermeasures Responding to the Aging of Population in Major Developed Countries and Reference for China. World Regional Studies. March 2013, Vol. 22. DOI: 10.3969/j.issn.1004-9479.2013.01.017

Wang, X., Liu Z. H., \& Zhang, H. (2010). Review and Forecast of Tourist Satisfaction Research. Journal of Beijing second foreign language institute, 2010, Vol.1.

Weber, K. (1997). The assessment of tourist satisfaction using the expectancy disconfirmation theory: a study of the German travel market in Australia. Pacific Tourism Review, 1, 35-45.

World Travel \& Tourism Council. (2018, March). Travel \& Tourism: Global Economic Impact \& Issues 2018. Retrieved from https://www.wttc.org/-/media/files/reports/economicimpact-research/documents-2018/global-economic-impact-and-issues-2018-eng.pdf 
World Tourism Organization. (2012). Special Report: Demographic Change and Tourism. UNWTO Publictions, 2012, Vol.26. Retrieved from http://cf.cdn.unwto.org/sites/all/files/pdf/unwtoapnewsletter26contents.pdf

Xu, J. F., Lin, F., Zhao, X. Y., \& Luo, Z. P. (2008). An Investigation on the Individual Tourist' s Demands in Beijing--Focus on One-day Tour of the Great Wall and the Ming Tombs. Journal of Beijing Union University (Humanities and Social Sciences). 2008, Vol. 04. ISSN : $1672-4917$

Yeoman, I., Hsu, C., Smith, K., Flatters, P., Backer, E., Baum, T., Benkendorff, P., Butterfield, S., Cothran, C., \& Davidson, R. (2010). Tourism and demography. Retrieved from https://ebookcentral.proquest.com

Xu, J. F. (2008). The Administrative Mode of Service System for Independent Tourists: Beijing's Problems and Countermeasures. Tourism Tribune. 2008, Vol. 08.

Zeithaml, V. A. (1987). Defining and relating price, perceived quality, and perceived value. Cambridge, MA: Marketing Science Institute. (pp. 87-101).

Zhang, G. R. (2000). Discuss the development of tourism in the capital. Investment in Beijing, 2000, Vol. 10-11

Zhang, H.Q. \& Lam, T. (1999). An analysis of mainland Chinese visitors' motivations to visit Hong Kong. Tourism Management, 20 (1999), pp. 587-593 


\section{Appendices}

Appendix1: Information handout for the participant (English translation)

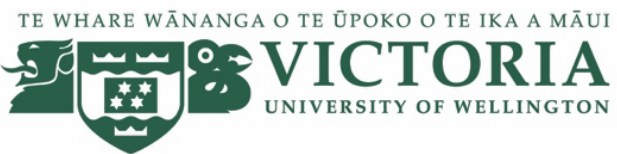

\section{INFORMATION FOR PARTICIPANT}

Dear Sir/Madam! You are invited to take part in this research. Please read this information before deciding whether or not to take part. If you decide to participate, thank you. If you decide not to participate, thank you for considering this request.

My name is Shanshan Li. I am a Master student in Commerce at Victoria University of Wellington in New Zealand. This research project is work towards my Master's thesis.

The project aims to examine the senior tourists' motivation and satisfaction of day trips. Your participation in this survey is extremely important to develop a deep understanding of the status of senior tourists on a one-day trip to Beijing.

This research has been approved by the Victoria University of Wellington Human Ethics Committee. The application reference number is 0000026937.

You have been invited to participate because my research is focused on senior tourists. If you agree to take part, you will complete a survey. The survey will ask you questions about tourism motivation and satisfaction. The survey will take you about 10 minutes to complete.

This research is anonymous. This means that nobody, including the researchers, will be aware of your identity. By answering it, you are giving consent for us to use your responses in this research. Your answers will remain completely anonymous and unidentifiable. Once 
you submit the survey, it will be impossible to retract your answer. Please do not include any personal identifiable information in your responses.

The information from my research will be used in my Master's thesis. It maybe used in conference presentations, and academic reports and publications.

If you have any questions, either now or in the future, please feel free to contact:

Student:

Name: Shanshan Li

Univercity email address:

lishan2@myvuw.ac.nz
Supervisor:

Name: Ian Yeoman

Role: Associate Professor

School: Victoria University of Wellington

Email: ian.yeoman@vuw.ac.nz

Phone: 044635717

Human Ethics Committee information

If you have any concerns about the ethical conduct of the research you may contact the Victoria University HEC Convenor: Dr Judith Loveridge. Email hec@vuw.ac.nz or telephone +64-4-463 6028 . 
Appendix2: Questionnaire for the participant (English translation)

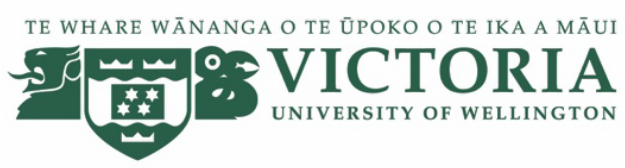

THE MOTIVATIONS AND SATISFACTIONS OF SENIOR TOURISTS: THE DAY TRIPS OF BEIJING RESIDENTS

Notes: Please tick $(V)$ the appropriate answer or fill in the information reflecting your viewpoints!

PART 1: PERSONAL INFORMATION (for statistical analysis purpose only)

What is your gender?

Male B. Female

What is your age?
A. $50-55$ years old
B. $56-60$ years old
C. $61-65$ years old
D. 66-70 years old
E. over 70 years old

What is your education?
A. Less than undergraduate
B. Undergraduate
C. Master Degree
D. Doctorate, PhD., DSc

What is your marital status?
A. Single
B. Married
C. Widowed
D. Divorce

What is your annual income?
A. Less than 50,000 CNY
B. $50,001-100,000$ CNY
C. $1000,001-200,000$ CNY
D. $200,001-300,000$ CNY
E. Over than $300,001 \mathrm{CNY}$ 
Please rate your health based on your personal circumstances. 5 is very healthy, 4 is healthy, 3 is normal, 2 is unhealthy, and 1 is unhealthy at all.
A. 5
B. 4
C. 3
D. 2
E. 1

\section{PART 2: TOURISM MOTIVATION AND SATISFACTION INFORMATION}

Based on your personal experience, please indicate the level of importance of these reason for your travel. If you have any other reasons not include in the table, please write in the last 5 rows of the table and rate it. Please write as many as possible.

(Please tick $(v)$ into the box that reflects your opinion from 1-not important at all to 5extremely important)

\begin{tabular}{|c|c|c|c|c|c|}
\hline \multirow[b]{2}{*}{ THE REASONS } & \multicolumn{5}{|c|}{ IMPORTANCE LEVELS } \\
\hline & $\begin{array}{l}\text { Not } \\
\text { important } \\
\text { at all }\end{array}$ & $\begin{array}{c}\text { Not } \\
\text { important }\end{array}$ & Neutral & Important & $\begin{array}{l}\text { Extremely } \\
\text { important }\end{array}$ \\
\hline $\begin{array}{l}\text { Share travel } \\
\text { experiences with } \\
\text { friends and } \\
\text { relatives. }\end{array}$ & 1 & 2 & 3 & 4 & 5 \\
\hline $\begin{array}{l}\text { Attend the cultural } \\
\text { events. }\end{array}$ & 1 & 2 & 3 & 4 & 5 \\
\hline $\begin{array}{l}\text { The availability of a } \\
\text { good restaurant and } \\
\text { delicious food. }\end{array}$ & 1 & 2 & 3 & 4 & 5 \\
\hline $\begin{array}{l}\text { Have someplace can } \\
\text { bought things on } \\
\text { trip. }\end{array}$ & 1 & 2 & 3 & 4 & 5 \\
\hline $\begin{array}{l}\text { Get a new } \\
\text { experience. }\end{array}$ & 1 & 2 & 3 & 4 & 5 \\
\hline $\begin{array}{l}\text { I want to see the } \\
\text { things that I don't } \\
\text { normally see. }\end{array}$ & 1 & 2 & 3 & 4 & 5 \\
\hline $\begin{array}{l}\text { There are some } \\
\text { places I have always } \\
\text { wanted to visit. }\end{array}$ & 1 & 2 & 3 & 4 & 5 \\
\hline $\begin{array}{l}\text { I want to get a rest } \\
\text { and relax. }\end{array}$ & 1 & 2 & 3 & 4 & 5 \\
\hline $\begin{array}{l}\text { I just want to slow } \\
\text { down. }\end{array}$ & 1 & 2 & 3 & 4 & 5 \\
\hline
\end{tabular}




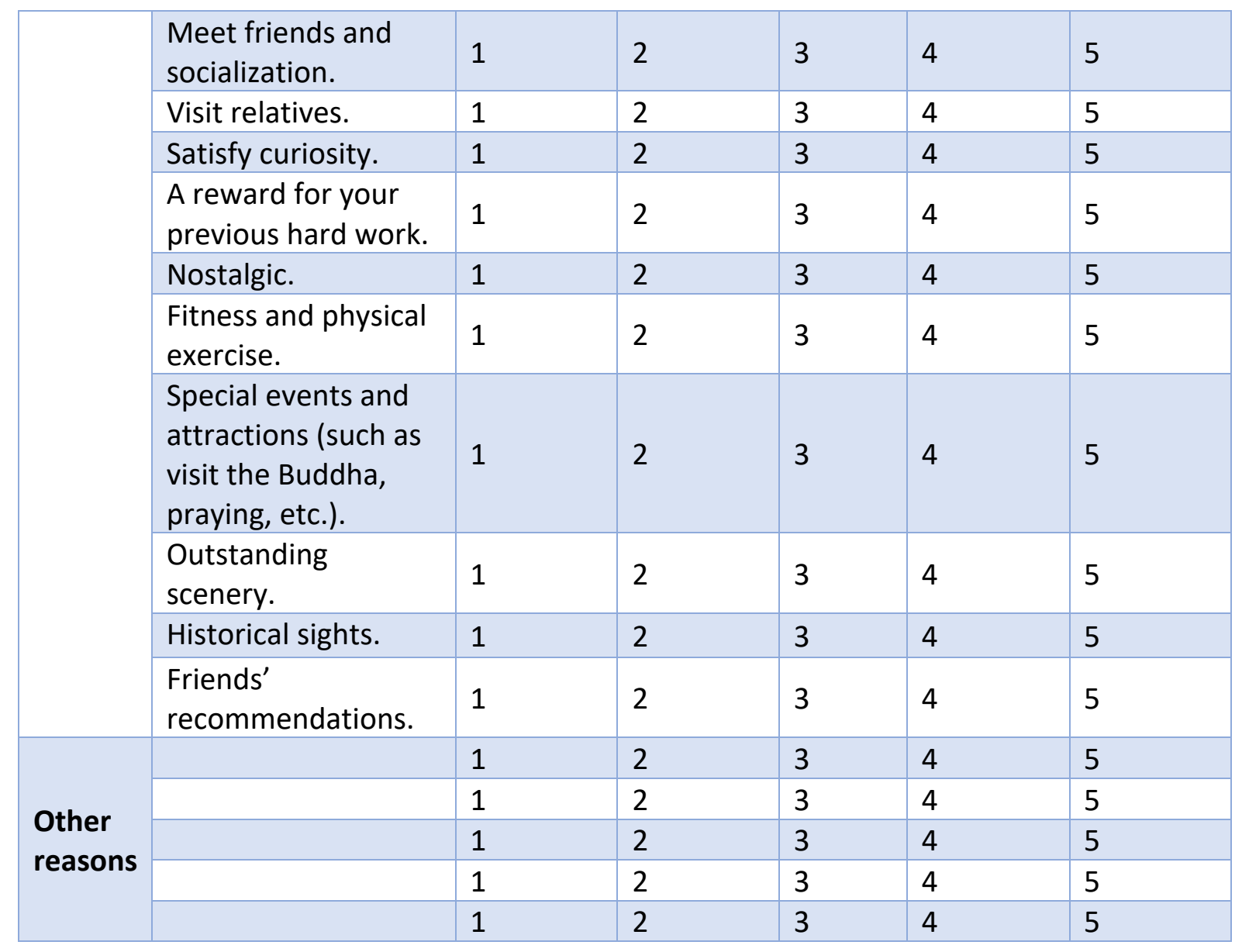

Please indicate the level of importance of the following factors that affect your travel plan based on your personal circumstances. If you are affected by any other factors not include in the table, please write in the last 5 rows of the table and rate it. Please write as many as possible.

(Please tick $(V)$ into the box that reflects your opinion from 1-not important at all to 5extremely important)

\begin{tabular}{|c|c|c|c|c|c|}
\hline \multirow[b]{2}{*}{ THE FACTORS } & \multicolumn{5}{|c|}{ IMPORTANCE LEVELS } \\
\hline & $\begin{array}{c}\text { Not } \\
\text { important } \\
\text { at all }\end{array}$ & $\begin{array}{l}\text { Not } \\
\text { important }\end{array}$ & Neutral & Important & $\begin{array}{l}\text { Extremely } \\
\text { important }\end{array}$ \\
\hline Personal Financials & 1 & 2 & 3 & 4 & 5 \\
\hline Discretionary time & 1 & 2 & 3 & 4 & 5 \\
\hline Health status & 1 & 2 & 3 & 4 & 5 \\
\hline $\begin{array}{l}\text { Season and weather } \\
\text { conditions }\end{array}$ & 1 & 2 & 3 & 4 & 5 \\
\hline Traffic condition & 1 & 2 & 3 & 4 & 5 \\
\hline
\end{tabular}




\begin{tabular}{|l|l|l|l|l|l|l|}
\hline & $\begin{array}{l}\text { Overall cost of travel } \\
\text { (including } \\
\text { transportation and } \\
\text { meals) }\end{array}$ & 1 & 2 & 3 & 4 & 5 \\
\hline \multirow{2}{*}{$\begin{array}{l}\text { Other } \\
\text { reasons }\end{array}$} & & 1 & 2 & 3 & 4 & 5 \\
\hline & & 1 & 2 & 3 & 4 & 5 \\
\hline & & 1 & 2 & 3 & 4 & 5 \\
\hline
\end{tabular}

Please indicate the level of importance of the following factors that affect your travel satisfaction based on your personal circumstances. If you are affected by any other factors not include in the table, please write in the last 5 rows of the table and rate it. Please write as many as possible.

(Please tick $(\mathrm{V})$ into the box that reflects your opinion from 1-not important at all to 5extremely important)

\section{IMPORTANCE LEVELS}

\begin{tabular}{|c|c|c|c|c|c|}
\hline \multirow[b]{2}{*}{ THE FACTORS } & \multicolumn{5}{|c|}{ IMPORTANCE LEVELS } \\
\hline & $\begin{array}{l}\text { Not } \\
\text { important } \\
\text { at all }\end{array}$ & $\begin{array}{c}\text { Not } \\
\text { important }\end{array}$ & Neutral & Important & $\begin{array}{l}\text { Extremely } \\
\text { important }\end{array}$ \\
\hline $\begin{array}{l}\text { Good shopping } \\
\text { facilities }\end{array}$ & 1 & 2 & 3 & 4 & 5 \\
\hline Attractive scenery & 1 & 2 & 3 & 4 & 5 \\
\hline $\begin{array}{l}\text { Quality of food and } \\
\text { beverage }\end{array}$ & 1 & 2 & 3 & 4 & 5 \\
\hline $\begin{array}{l}\text { The level of } \\
\text { participation in } \\
\text { activities during the } \\
\text { trip }\end{array}$ & 1 & 2 & 3 & 4 & 5 \\
\hline $\begin{array}{l}\text { Convenient } \\
\text { transport }\end{array}$ & 1 & 2 & 3 & 4 & 5 \\
\hline Weather conditions & 1 & 2 & 3 & 4 & 5 \\
\hline $\begin{array}{l}\text { Number of tourists } \\
\text { in scenic spots }\end{array}$ & 1 & 2 & 3 & 4 & 5 \\
\hline $\begin{array}{l}\text { Scenic reception } \\
\text { capacity }\end{array}$ & 1 & 2 & 3 & 4 & 5 \\
\hline Scenic security & 1 & 2 & 3 & 4 & 5 \\
\hline $\begin{array}{l}\text { Service quality of } \\
\text { scenic service } \\
\text { personnel }\end{array}$ & 1 & 2 & 3 & 4 & 5 \\
\hline
\end{tabular}




\begin{tabular}{|l|l|l|l|l|l|l|}
\hline & $\begin{array}{l}\text { Overall cost of travel } \\
\text { (including } \\
\text { transportation and } \\
\text { meals) }\end{array}$ & 1 & 2 & 3 & 4 & 5 \\
\hline \multirow{2}{*}{$\begin{array}{l}\text { Other } \\
\text { reasons }\end{array}$} & 1 & 2 & 3 & 4 & 5 \\
\hline & & 1 & 2 & 3 & 4 & 5 \\
\hline & & 1 & 2 & 3 & 4 & 5 \\
\hline
\end{tabular}

Please recalling the most impressive one-day trip in two years and answer the questions below:

What was the level of your expectation of this tour?

A. My expectations for this trip were extremely low.

B. My expectations for this trip were low.

C. My expectations for this trip were neutral.

D. My expectations for this trip were high.

E. My expectations for this trip were extremely high.

How was the quality of this tour?
A. The quality of this trip was extremely low.
B. The quality of this trip was low.
C. The quality of this trip was neutral.
D. The quality of this trip was high.
E. The quality of this trip was extremely high.

Were you satisfied with this tour?
A. I was extremely dissatisfied.
B. I was dissatisfied.
C. I was neutral.
D. I was satisfied.
E. I was extremely satisfied. 
Would you recommend these spots to others if you were satisfied?
A. Yes.
B. No.

Whether you would tell your friends and relatives about the unpleasant experience of this trip if you were not satisfied?

Yes. B. No. 